\author{
UNIVERSIDADE DE SÃO PAULO \\ ESCOLA DE ENFERMAGEM DE RIBEIRÃO PRETO
}

FABIANA CRISTINA JULIÃO

Avaliação das condições microbiológicas

e físico-químicas da água de reservatório domiciliar e predial: importância da qualidade dessa água no contexto da saúde pública.

Ribeirão Preto

2011 


\section{Avaliação das condições microbiológicas e físico-químicas da água de reservatório domiciliar e predial: importância da qualidade dessa água no contexto da saúde pública.}

Tese apresentada à Escola de Enfermagem de Ribeirão Preto da Universidade de São Paulo para obtenção do título de Doutor em Ciências.

Área de Concentração: Enfermagem em Saúde Pública.

Linha de Pesquisa: Saúde Ambiental

Orientador: Profa Dra Susana Inés Segura Muñoz

Ribeirão Preto 
Autorizo a reprodução e divulgação total ou parcial deste trabalho, por qualquer meio convencional ou eletrônico, para fins de estudo e pesquisa, desde que citada a fonte.

\author{
Catalogação da Publicação \\ Serviço de Documentação da Enfermagem \\ Escola de Enfermagem de Ribeirão Preto da Universidade de São Paulo
}

Julião, Fabiana Cristina.

Avaliação das condições microbiológicas e físico-químicas da água de reservatório domiciliar e predial: importância da qualidade dessa água no contexto da saúde pública / Fabiana Cristina Julião; orientador: Susana Inés Segura-Muñoz. - Ribeirão Preto, 2011.

$157 f$.

Tese (Doutorado) - Escola de Enfermagem de Ribeirão Preto da Universidade de São Paulo, 2011.

1. Água. 2. Reservatórios. 3. Análise bacteriológica. 4. Análise parasitológica. 5. Metais. 
Julião, F.C. Avaliação das condições microbiológicas e físico-químicas da água de reservatório domiciliar e predial: importância da qualidade dessa água no contexto da saúde pública.Tese apresentada à Escola de Enfermagem de Ribeirão Preto da Universidade de São Paulo para obtenção do título de Doutor na área de concentração Enfermagem em Saúde Pública.

Aprovado em:

Banca Examinadora

Prof. Dr.

Instituição:

Assinatura:

Prof. Dr.

Instituição:

Assinatura:

Prof. Dr.

Instituição:

Assinatura:

Prof. Dr.

Instituição:

Assinatura:

Prof. Dr.

Instituição:

Assinatura: 


\section{Dedicatória}

Aos meus pais, Maria Helena e Rachid, por todo o amor, compreensão e exemplos de dignidade, honradez e conquistas.

"Se todos fossem iguais a você(s)...Que maravilha viver." (Vinícius de Moraes)

À minha prima Andréa Fiorin que nos deixou, ainda tão jovem.Dedico este trabalho aos dias de nossa infância, ao companheirismo no início de nossa vida escolar e aos momentos que compartilhamos da sua alegria.

"O tempo não pára. Só a saudade é que faz as coisas pararem no tempo." (Mário Quintana) 


\section{Agradecimento Especial}

Agradeço especialmente à Profa Dra Susana Inés Segura-Muñoz,minha Orientadora e Amiga. Obrigada pela dedicação, carinho e apoio em todos os momentos.

"Feliz aquele que transfere o que sabe e aprende o que ensina." (Cora Coralina) 


\section{Agradecimentos}

Agradeço a Deus pelo dom da vida e por iluminar com fé, esperança e felicidade a minha caminhada.

Aos meus irmãos, Fernando, Marcos e Márcio por todo o carinho e incentivo.

Às minha tias, Maria Luiza e Maria José, pelo apoio em todos os momentos.

Ao Ricardo Rodrigues, pelo carinho, compreensão, incentivo e momentos felizes compartilhados nos últimos anos.

À Karina Aparecida de Abreu Tonani, pela amizade, cumplicidade, incentivo e apoio diários. Agradeço seu exemplo de generosidade e competência.

À Marina Smidt Celere, pela amizade e palavras de incentivo.

Aos meus amigos do Laboratório de Parasitologia e Ecotoxicologia Ambiental: Osmar de Oliveira Cardoso, Renato Igor da Silva Alves, Mariana Frari Ragazzi, Carolina de Freitas Sampaio; agradeço pelo companheirismo e bons momentos vividos diariamente.

Aos meus queridos amigos, Mariana de Senzi Zancul, Vagner Tadeu Paes de Oliveira, Giovana Bottura, Maria Claudia Guidetti Campos, Ana Carolina Malaspina, Karla Monteiro Paranhos, Carla Cresoni, Susel Requena, Jacyara Aparecida Fabbri; mesmo à distância fizeramse presentes em todos os momentos.

Às amigas Meire Nikaido, Janaína Castania, Jamyle Calencio Grigoletto, Ana Carolina Scarpel Moncaio pela amizade e companheirismo durante o doutorado.

À Profa Dra Angela Maria Magosso Takayanagui pela dedicação, sugestões e .incentivo durante a pós-graduação.

À Tania Maria Beltramini Trevilato, Profa Dra Ana Bócio Sanz, Dr Martí Nadal e Dr Josep L. Domingo pela cooperação e participação na realização deste estudo. 
Aos funcionários da Escola de Enfermagem de Ribeirão Preto da Universidade de São Paulo em especial à Shirley Ferreira de Figueiredo, pela paciência e disponibilidade em todos os momentos.

Aos funcionários e alunos do Laboratorio de Toxicología y Salud Ambiental de La Universidad Rovira i Virgilli, na Espanha.

Aos gerentes das Unidades Básicas de Saúde do município de Ribeirão Preto-SP pela cooperação.

Aos participantes da pesquisa, moradores "anônimos" de Ribeirão Preto-SP, que se dispuseram a abrir as portas de suas casas para que a coleta de dados fosse realizada.

Aos funcionários da Secretaria Municipal de Saúde de Ribeirão PretoSP, pelo auxílio e autorização para a coleta de dados.

Ao Rafael Gutierre , coordenador do IBGE em Ribeirão Preto,.pela disponibilidade e cooperação.

À Márcia Marques de Moraes Alves, chefe da Divisão de Laboratório e Tratamento do Departamento de Água e Esgoto de Ribeirão Preto-SP, pelo apoio e colaboração.

À Sophia, pela alegre companhia canina em todos esses anos.

À Fundação de Amparo à Pesquisa do Estado de São Paulo (FAPESP), pelo auxílio financeiro.

$\grave{A}$ todos aqueles, que direta ou indiretamente participaram da elaboração e realização desta pesquisa. 


\section{Epígrafe}

"A vida não é regida pela vontade ou determinação. A vida é um conjunto de nervos, fibras e células que se formam lentamente, onde se esconde o pensamento e a paixão sonha seus sonhos." (Oscar Wilde) 


\section{RESUMO}

JULIÃO, F.C. Avaliação das condições microbiológicas e físicoquímicas da água de reservatório domiciliar e predial: importância da qualidade dessa água no contexto da saúde pública. 2011.157f. Tese (Doutorado) - Escola de Enfermagem de Ribeirão Preto, Universidade de São Paulo, Ribeirão Preto, 2011.

$\mathrm{Na}$ atualidade, as questões relacionadas ao monitoramento da qualidade da água destinada ao consumo humano, têm sido motivo de preocupação nos países de todos os continentes. No Brasil, no início do século XIX, houve uma melhoria da infraestrutura das redes de abastecimento público de água, no entanto, diante das intermitências do fornecimento surgiu a necessidade da utilização de reservatórios de água para suprir a demanda diária de consumo, principalmente nas áreas urbanas. Os reservatórios podem garantir a quantidade de água necessária diariamente, porém a ausência de cuidados mínimos com a limpeza e manutenção destes recipientes podem prejudicar a qualidade da água a ser consumida. Este trabalho objetivou avaliar as condições microbiológicas e físico-químicas da água do reservatório de 217 domicílios e de 23 Unidades Básicas de Saúde no município de Ribeirão Preto-SP, a fim de se obter informações sobre a condição sanitária da água consumida após o armazenamento, bem como as ações da população relacionadas à manutenção dos reservatórios domésticos. Foram realizadas análises bacteriológicas, utilizando-se a Técnica de Tubos Múltiplos com substrato cromogênico; análise parasitológica a partir da sedimentação espontânea e análise para metais através de Espectroscopia com Plasma Induzido-Espectroscopia de Massa. A partir da coleta de dados foi evidenciado que a população tem informações sobre a necessidade da limpeza do reservatório domiciliar, porém não a realiza no período recomendado, apesar da água armazenada neste local ser comumente utilizada para atividades de higiene pessoal e limpeza doméstica. Os resultados das análises e os testes estatísticos revelaram valores que se enquadram aos parâmetros recomendados pela Portaria 518/2004 do Ministério da Saúde. A água do município é proveniente de um manancial subterrâneo e o monitoramento de suas características é realizado periodicamente pela instituição municipal responsável pelo abastecimento público e esses fatores têm colaborado para a manutenção da qualidade da água fornecida em Ribeirão Preto-SP. O uso rotineiro da água do reservatório diminui o tempo de armazenamento, mantendo condições sanitárias adequadas, no entanto, a população necessita ser sensibilizada sobre a importância da limpeza e manutenção dos recipientes para garantir o consumo de água segura, evitando riscos à saúde da população.

Palavras-Chave: Água. Reservatórios. Análise bacteriológica. Análise parasitológica. Metais. 


\begin{abstract}
JULIÃO, F.C. Evaluation of microbiological and physicochemical conditions of water from home and building reservoirs: the importance of the quality of such water in the public health context. 2011.157f. Dissertation (Doctoral Program) - University of São Paulo, College of Nursing, Ribeirão Preto, 2011.

Issues related to the monitoring of the quality of water destined for human consumption have been a concern around the world. The public water supply infrastructure was improved in Brazil at the beginning of the $19^{\text {th }}$ century, however intermittent water supply requires the use of water reservoirs to meet the demand of daily consumption, especially in urban areas. Reservoirs can ensure the quantity of daily water requirements, but a lack of minimum care concerning cleaning and maintenance of such reservoirs may threaten the quality of water to be consumed. This study evaluated the microbiological and physiochemical conditions of water in the reservoirs of 217 houses and 23 Primary Health Units in Ribeirão Preto, SP, Brazil to obtain information concerning the sanitary condition of water consumed after storage, as well as actions on the part of the population related to the maintenance of domestic reservoirs. Bacteriological analyses were performed using the Multiple Tube method with a chromogenic substrate; parasitological analysis based on spontaneous sedimentation and analysis of metals through Inductively Coupled Plasma-Mass Spectroscopy (ICP-MS). The data collections revealed that the population is aware of the need to clean house reservoirs. However, they do not perform it within the recommended period, even though they use the water stored for personal hygiene and domestic cleansing. The results of the analyses and statistical tests revealed values that fall within the parameters recommended by Ministry of Health Decree 518/2004. The water in the city comes from an underground spring and the company responsible for the city's public supply monitors its characteristics periodically; factors that collaborate in the maintenance of the quality of the water supplied in Ribeirão Preto, SP, Brazil. The routine use of water from the reservoir reduces the storage time keeping appropriate sanitary conditions. The population, though, needs to be regularly sensitized of the importance of cleaning and maintaining this reservoir to ensure safe water consumption and to avoid risks to the health of population.
\end{abstract}

Key-words: Water. Reservoirs. Bacteriological analysis. Parasitological analysis. Metals. 


\section{RESUMÉN}

JULIÃO, F.C. Evaluación de las condiciones microbiológicas y físicoquímicas del agua de reservatorios domiciliares e institucionales: importancia de la calidad de esa agua en el contexto de la salud pública. 2011. 157f. Tesis (Doctorado) - Escuela de Enfermería de Ribeirão Preto, Universidad de São Paulo, Ribeirão Preto, 2011.

En la actualidad, las cuestiones relacionadas al monitoreo de la calidad del agua destinada al consumo humano, ha sido motivo de preocupación en los países de todos los continentes. En Brasil, en el inicio del siglo XIX, hubo una mejoría de la infraestructura de las redes de abastecimiento público de agua, sin embargo, frente a la intermitencia del fornecimiento, surgió la necesidad de la utilización de reservatorios de agua para suplir la demanda diaria de consumo, principalmente en las áreas urbanas. Los reservatorios pueden garantizar la cantidad de agua necesaria diariamente, pero la ausencia de cuidados mínimos de limpieza y mantenimiento de esos recipientes pueden perjudicar la calidad del agua a ser consumida. Este trabajo tuvo como objetivo evaluar las condiciones microbiológicas y físicoquímicas del agua de reservatorio de 217 domicilios y de 23 Unidades Básicas de Salud en el municipio de Ribeirão Preto, SP, a fin de obtener informaciones sobre la condición sanitaria del agua consumida después del almacenamiento, así como las acciones de la población relacionadas con el mantenimiento de los reservatorios domésticos. Fueron realizados análisis bacteriológicos, utilizando la Técnica de Tubos Múltiplos con Substrato Cromogénico, análisis parasitológicos por métodos de sedimentación espontánea y análisis de metales por el método de Espectroscopia con Plasma Inducido- Espectroscopia de Masas. A partir de la colecta de datos, fue evidenciado que la población tiene informaciones sobre la necesidad de la limpieza del reservatorio, sin embargo, no la realiza en el periodo recomendado a pesar utilizar esa agua para actividades de higiene personal y limpieza domestica. Los resultados de los análisis revelaron valores que se encuadran en los parámetros recomendados por la Resolución 518/2004 del Ministerio da Salud de Brasil. El agua del municipio es proveniente de un manantial subterráneo y el monitoreo de sus características es realizado periódicamente por la institución municipal responsable por el abastecimiento público, eses factores deben estar colaborando para el mantenimiento de la calidad de agua ofrecida en Ribeirão Preto- SP. El uso frecuente del agua de reservatorios disminuye el tiempo de retención de almacenamiento, manteniendo condiciones sanitarias adecuadas, sin embargo, la población necesita ser sensibilizada sobre la importancia de la limpieza y mantenimiento de los recipientes para garantizar el consumo de agua segura evitando riesgos a la salud de la población.

Palabras-claves: Agua. Reservatorios. Análisis Bacteriológicos. Análisis parasitológicos. Metales 


\section{LISTA DE FIGURAS}

Figura 1 - Percentual de moradores em domicílios particulares permanentes urbanos com acesso à água canalizada de rede geral, segundo regiões geográficas.

Figura 2 - Percentual de pessoas em domicílios particulares permanentes urbanos com esgotamento por rede coletora ou fossa séptica, segundo as regiões geográficas.

Figura 3 - Representação gráfica da sequência do tratamento convencional de água em uma ETA....

Figura 4 - Representação gráfica do processo de coagulação.

Figura 5 - Representação gráfica do processo de floculação.

Figura 6 - Representação gráfica do processo de sedimentação.

Figura 7 - Representação gráfica do processo de filtração lenta.

Figura 8 - Representação gráfica do processo de filtração rápida descendente.

Figura 9 - Fluxograma de uma ETA - captação de água superficial.

Figura 10 - Poço artesiano com reservatório localizado no município de Ribeirão Preto / Adição de cloro e flúor na água captada.....

Figura 11 - Representação gráfica da instalação de água nos domicílios com sistema misto.

Figura 12 - Representação gráfica da caixa d'água e ramais de distribuição

Figura 13 - Representação gráfica do desenvolvimento de um biofilme.......

Figura 14 - Localização do município de Ribeirão Preto no Estado de São Paulo.

Figura 15 - UBSs do município de Ribeirão Preto-SP, onde foram coletadas amostras de água...

Figura 16 - Vista parcial de quatro UBS localizadas no município de Ribeirão Preto-SP, onde foram coletadas amostras de água.....

Figura 17 - Representação gráfica de um setor censitário do município de Ribeirão Preto - SP, destacado no centro do mapa.

Figura 18 - Representação gráfica da posição do domicílio sorteado no setor censitário.

Figura 19 - Coleta de amostras de água para análise parasitológica, bacteriológica e metais tóxicos, realizada em domicílio localizado no município de Ribeirão Preto. 
Figura 20 - Esquema ilustrativo do preparo das diluições decimais da

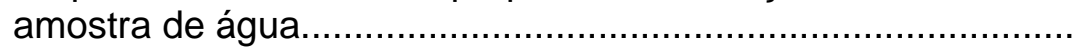

Figura 21 - Confirmação de teste positivo para coliformes totais, visualização de coloração amarelada; confirmação de teste positivo para Escherichia coli, visualização de fluorescência azul......

Figura 22 - Controle positivo e negativo após esterilização

Figura 23 - Controle Positivo realizado juntamente com a análise das amostras de água. Verificação da Presença/Ausência de Coliformes totais e Escherichia coli.

Figura 24 - Amostras de água em cálices de sedimentação e câmara de Sedgewick-Rafter preparada para a leitura de ovos, cistos e larvas de parasitas

Figura 25 - Distribuição da frequência dos períodos de limpeza do reservatório domiciliar de água, de acordo com as informações fornecidas pelos participantes $(n=78)$.

Figura 26 - Produtos e objetos considerados adequados para limpeza do reservatório domiciliar de água, de acordo com os participantes......

Figura 27 - Cômodos do domicílio que recebem água diretamente do reservatório domiciliar, de acordo com os participantes.

Figura 28 - Leitura do resultado de análise bacteriológica de amostras de água, utilizando-se a câmara de luz ultravioleta (366nm, 6W) após permanecerem armazenadas em estufa de cultura a $35 \pm$ $0,5^{\circ} \mathrm{C}$, durante $24 \pm 2$ horas

Figura 29 - Concentração de $\mathrm{Cr}, \mathrm{Cu}, \mathrm{Mn}, \mathrm{Ni}, \mathrm{Pb}$ e $\mathrm{Zn}$ nas amostras de água provenientes dos reservatórios $e$ da rede de abastecimento público no município de Ribeirão Preto,SP......... 


\section{LISTA DE TABELAS}

Tabela 1 Resultados da análise bacteriológica obtidos em amostras de água de domicílios $(n=217)$ e UBSs $(n=23)$, no município de Ribeirão Preto, a partir da Técnica de Tubos Múltiplos com substrato cromogênico...

Tabela 2 Resultados da análise parasitológica obtidos em amostras de água de domicílios $(n=217)$ e UBSs $(n=23)$ no município de Ribeirão Preto, a partir de sedimentação espontânea com posterior análise na Câmara de SedgewickRafter

Tabela 3 Concentração de metais (mg/L) em amostras de água analisadas $(n=427)$, provenientes de reservatórios domiciliares, de UBSs e da rede de abastecimento público, no município de Ribeirão Preto-SP.

Tabela 4 Concentração de metais $(\mathrm{mg} / \mathrm{L})$ em amostras de água analisadas $(n=217)$ segundo 0 material do reservatório de água (amianto e polietileno)......

Tabela 5 Concentração média de metais $(\mathrm{mg} / \mathrm{L})$ em amostras de água analisadas $(n=427)$ segundo a localização por região no município de Ribeirão Preto-SP.

Tabela $6 \quad$ Valores de temperatura, $\mathrm{pH}$ e cloro observados nas amostras de água de reservatórios domiciliares de UBSs no município de Ribeirão Preto-SP. 


\section{LISTA DE ABREVIATURAS E SIGLAS}

$\begin{array}{ll}\text { ADWG } & \text { Australian Drinking Water Guidelines } \\ \text { APHA } & \text { American Public Health Association } \\ \text { ATSDR } & \text { Agency for Toxic Substances and Disease Registry } \\ \text { CDC } & \text { Centers for Disease Control and Prevention } \\ \text { CETESB } & \text { Companhia de Tecnologia de Saneamento Ambiental } \\ \text { CGSAT } & \text { Coordenação Geral de Saúde do Trabalhador } \\ \text { CGVAM } & \text { Coordenação Geral de Vigilância em Saúde Ambiental } \\ \text { CSE } & \text { Centro de Saúde Escola } \\ \text { DAERP } & \text { Departamento de Água e Esgotos de Ribeirão Preto } \\ \text { EERP } & \text { Escola de Enfermagem de Ribeirão Preto } \\ \text { EPA } & \text { Environmental Protection Agency } \\ \text { ETA } & \text { Estação de Tratamento da Água } \\ \text { FUNASA } & \text { Fundação Nacional de Saúde } \\ \text { IARC } & \text { International Agency for Research on Câncer } \\ \text { IBGE } & \text { Instituto Brasileiro de Geografia e Estatística } \\ \text { ICP-MS } & \text { Inductively Coupled Plasma Mass Spectroscopy } \\ \text { IPEA } & \text { Instituto de Pesquisa Econômica Aplicada } \\ \text { LEPA } & \text { Laboratório de Ecotoxicologia e Parasitologia Ambiental } \\ \text { NMP } & \text { Número Mais Provável } \\ \text { NSF } & \text { Núcleo de Saúde da Família } \\ \text { OMS } & \text { Organização Mundial da Saúde } \\ \text { ONU } & \text { Organização das Nações Unidas } \\ \text { PAHO } & \text { Pan American Health Organization } \\ \text { PNAD } & \text { Pesquisa Nacional por Amostra de Domicílios } \\ \text { PVC } & \text { Polyvinyl chloride (Poli Cloreto de Vinila) } \\ \text { SISAGUA } & \text { Sistema de Informação de Vigilância da Qualidade da Água para } \\ \text { SNC } & \text { Consumo Humano } \\ \text { SUS } & \text { Sistema Nervoso Central } \\ \text { UBDS } & \text { Sistema Único de Saúde } \\ \text { UBS } & \text { Unidade Distrital Básica de Saúde } \\ \text { UFBA } & \text { Unidade Básica de Saúde } \\ \text { UNESCO } & \text { Universidade Federal da Bahia } \\ \text { UNICEF } & \text { United Nations Educational, Scientific and Cultural Organization } \\ & \end{array}$




$\begin{array}{ll}\text { USP } & \text { Universidade de São Paulo } \\ \text { VIGIAGUA } & \text { Vigilância em Saúde Ambiental relacionada à Qualidade da Água } \\ & \text { para Consumo Humano } \\ \text { VIGIAR } & \text { Vigilância em Saúde de Populações Expostas à Poluição do Ar } \\ \text { VIGIDESASTRES } & \text { Vigilância em Saúde Ambiental relacionada aos riscos } \\ & \text { decorrentes de Desastres Naturais } \\ \text { VIGIPEQ } & \text { Vigilância em Saúde de Populações Expostas a Contaminantes } \\ \text { VIGIQUIM } & \text { Químicos } \\ \text { VIGilância Ambiental em Saúde Relacionada a Substâncias } \\ \text { Químicas } \\ \text { Vigilância em Saúde de Populações Expostas a Solo } \\ \text { Contaminado } \\ \text { WhO }\end{array}$




\section{LISTA DE SÍMBOLOS}

\begin{tabular}{|c|c|}
\hline$\%$ & porcentagem \\
\hline \& & e \\
\hline.$d$ & por dia \\
\hline$<$ & menor que \\
\hline \pm & mais ou menos \\
\hline (B) & marca registrada \\
\hline${ }^{\circ} \mathrm{C}$ & graus Celsius \\
\hline$\mu g / L$ & microgramas por litro \\
\hline $\mathrm{Al}$ & alumínio \\
\hline As & arsênio \\
\hline BA & Bahia \\
\hline $\mathrm{Be}$ & berílio \\
\hline $\mathrm{Ca}$ & cálcio \\
\hline $\mathrm{Cd}$ & cádmio \\
\hline $\mathrm{Cl}_{2}$ & cloro \\
\hline $\mathrm{cm}$ & centímetro \\
\hline Co & cobalto \\
\hline $\mathrm{Cr}$ & cromo \\
\hline $\mathrm{Cu}$ & cobre \\
\hline $\mathrm{Fe}$ & ferro \\
\hline$g$ & grama \\
\hline $\mathrm{h}$ & hora \\
\hline $\mathrm{Hg}$ & mercúrio \\
\hline HNO3 & ácido nítrico \\
\hline 12 & iodo \\
\hline $\mathrm{KI}$ & iodeto de potássio \\
\hline $\mathrm{Km}^{2}$ & kilômetro quadrado \\
\hline $\mathrm{Km}^{3}$ & kilômetro cúbico \\
\hline L & litro \\
\hline $\mathrm{m}$ & metro \\
\hline $\mathrm{m}^{2}$ & metro quadrado \\
\hline $\mathrm{m}^{3}$ & metro cúbico \\
\hline $\mathrm{mg} / \mathrm{L}$ & miligrama por litro \\
\hline$m$ & mililitro \\
\hline
\end{tabular}




\begin{tabular}{ll}
$\mathrm{mm}$ & milímetro \\
$\mathrm{mm}^{3}$ & milímetro cúbico \\
$\mathrm{Mn}$ & manganês \\
$\mathrm{n}^{\circ}$ & número \\
$\mathrm{Ni}$ & níquel \\
$\mathrm{nm}$ & nanômetro \\
$\mathrm{Pb}$ & chumbo \\
$\mathrm{pH}$ & potencial hidrogeniônico \\
$\mathrm{q} . \mathrm{s} . \mathrm{p}$. & quantidade suficiente para \\
$\mathrm{RJ}$ & Rio de Janeiro \\
$\mathrm{Sn}$ & estanho \\
$\mathrm{sp}$ & espécie \\
$\mathrm{SP}$ & São Paulo \\
$\mathrm{spp}$ & espécies \\
$\mathrm{B}$ & beta \\
$\mathrm{TI}$ & tálio \\
$\mathrm{V}$ & vanádio \\
$\mathrm{W}$ & watt \\
$\mathrm{XIX}$ & dezenove \\
$\mathrm{Zn}$ & zinco \\
\hline
\end{tabular}




\section{SUMÁRIO}

2.1. Acesso à água de qualidade.

2.2. Água destinada ao consumo humano e padrões de potabilidade............... 30

2.3.Água e sua relação com a saúde pública................................................... 33

2.4.Reservatórios domiciliares de água e sua relevância na rede de distribuição de água potável.

3 .OBJETIVOS

3.1. Objetivo geral.

3.2. Objetivos específicos.

4.1. Delineamento da pesquisa

4.2. Local de estudo

4.3. Coleta de informações sobre a limpeza e manutenção dos reservatórios domiciliares de água.

4.4. Coleta das amostras.................................................................. $\quad 70$

4.5. Preparação e análise das amostras...................................................... 72

4.6. Leitura dos valores de cloro e $\mathrm{pH}$......................................................... $\quad 79$

4.7. Análise dos resultados........................................................................ 80

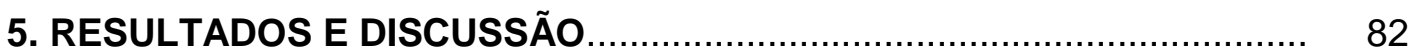

5.1. Limpeza e manutenção dos reservatórios domiciliares de água............... 82

5.2. Análise bacteriológica........................................................................ 87

5.3. Análise parasitológica...................................................................... 92

5.4. Análise de metais............................................................................ 94

5.5. Análise físico-química....................................................................... 100

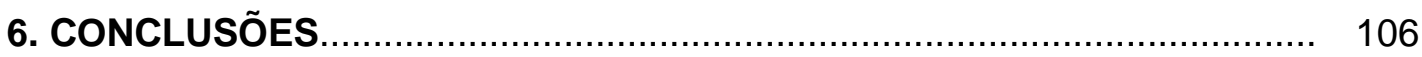

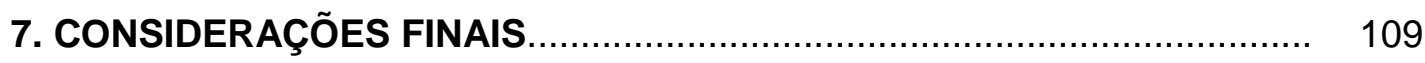

8.ATIVIDADES CIENTÍFICO-ACADÊMICAS ........................................ 112 
APÊNDICES

Apêndice A -Termo de Consentimento Livre e Esclarecido.

Apêndice B - Questionário sobre a limpeza do reservatório domiciliar.

Apêndice $C$ - Concentração de metais em amostras de água de reservatórios e de pontos da rede de abastecimento público.

Apêndice D - Testes Estatísticos das concentrações de metais em amostras de água de reservatório de amianto e polietileno.

Apêndice $\mathrm{E}$-Testes Estatísticos das concentrações de metais em amostras de água das regiões do município de Ribeirão Preto-SP.....

ANEXOS

Anexo A - Parecer do Comitê de Ética em Pesquisa da Escola de

Enfermagem de Ribeirão Preto da Universidade de São Paulo 


\section{1- INTRODUÇÃ̃O}


A água é fundamental para a manutenção de ecossistemas saudáveis, para a sobrevivência dos seres vivos e desenvolvimento sócio econômico da população mundial (ORGANIZAÇÃO DAS NAÇÕES UNIDAS (ONU), 2007). A água é um bem essencial à vida (CONCEIÇÃO et al., 2009). Utilizada para inúmeras finalidades, tais como, uso doméstico, irrigação na agricultura, produção industrial, geração de energia elétrica, lazer e turismo, além das atividades nos serviços de saúde.

Este recurso natural tem sido motivo de preocupação mundial diante das ameaças da poluição, do seu uso insustentável e irracional, do risco de escassez e contaminação, sendo preciso garantir que todos tenham acesso à água de boa qualidade (CONCEIÇÃO et al., 2009).

Do volume total de água doce do planeta $\left(34,6\right.$ milhões de $\left.\mathrm{Km}^{3}\right)$, somente cerca de 10,5 milhões de $\mathrm{Km}^{3}$ podem ser utilizados para a vida vegetal e animal nas terras emersas, pois 24,1 milhões encontram-se nas calotas polares, geleiras e solos gelados. Destes 10,5 milhões, aproximadamente 98,7\% correspondem à água subterrânea, e apenas 0,9\% correspondem ao volume de água doce superficial, diretamente disponível para a demanda humana (GOHRINGER, 2006).

Com o aumento da população mundial e consequentemente da demanda por captação de águas subterrâneas e superficiais, ocorre uma excessiva pressão sobre o meio ambiente, fortemente representada pela crescente poluição e contaminação dos recursos hídricos, em nível mundial, refletindo num quadro de escassez de água em diversas regiões (ONU, 2007).

O abastecimento de água de qualidade e em quantidade suficiente torna-se imprescindível diante da prevenção de uma série de enfermidades relacionadas à água (FREITAS; BRILHANTE; ALMEIDA, 2001; JENSEN et al., 2002). No entanto, este processo só é eficiente quando existe um monitoramente da qualidade da água a ser consumida, evitando-se possíveis riscos à saúde de quem a consome.

Neste contexto, torna-se necessário garantir que a água destinada ao consumo humano reúna as condições mínimas para que possa ser ingerida ou 
utilizada pelos consumidores sem causar danos à saúde, mediante a implementação de programas de monitoramento e vigilância em saúde. Essas ações de controle são realizadas desde as Estações de Tratamento de Água até a entrada da mesma nos domicílios (no hidrômetro/cavalete) e a partir deste ponto a água a ser consumida está sob responsabilidade do morador.

$\mathrm{Na}$ atualidade, é crescente a preocupação com o desenvolvimento de ações direcionadas à saúde humana e prevenção de doenças relacionadas ao acesso e consumo de água (WHO, 2008; JENSEN et al., 2002; QUICK et al., 2002; TREVETT; CARTER; TYRREL, 2005), possibilitando a melhoria das condições de vida das populações em todos os continentes. 


\section{REVISÃO DA LITERATURA}




\subsection{Acesso à água de qualidade}

Existem várias maneiras de definir a escassez de água, caracterizada principalmente quando o impacto interfere nas atividades dos utilizadores ou na qualidade da água, na medida em que a demanda, incluindo o ambiente natural, não pode ser plenamente satisfeita.

Considera-se a ocorrência de escassez de água quando a quantidade diária disponível para uma pessoa é inferior a $1.000 \mathrm{~m}^{3}$, incluindo a água utilizada para as atividades domésticas, alimentação e higiene, além daquela destinada ao consumo direto, a partir da ingestão (UNITED NATIONS EDUCATIONAL, SCIENTIFIC AND CULTURAL ORGANIZATION (UNESCO), 2009).

A escassez de água é um conceito relativo, muitas vezes determinado por comportamentos habituais da população humana.

Uma sociedade que enfrenta escassez de água, normalmente, tem opções para lidar com tal fenômeno, no entanto, a pouca quantidade de água disponível somada ao crescimento populacional e desenvolvimento econômico, desencadeiam uma escassez de forma acentuada, implicando na falta de soluções para tal problema (ONU, 2007).

Em menos de 25 anos, aproximadamente $67 \%$ dos habitantes do planeta residirão em países com graves problemas de abastecimento de água, especialmente na África do Norte, no Oriente Médio e na Ásia (UNESCO, 2009).

Segundo a United Nations Educational, Scientific and Cultural Organization (UNESCO), 1 em cada 4 pessoas, da população mundial, não tem acesso a água potável e $40 \%$ não dispõe de serviços de saneamento. Fatores diretamente relacionados à precária condição socioeconômica da população atingida, uma vez que, em média, as pessoas sem acesso a estes serviços, sobrevivem com menos de 2 dólares por dia (UNESCO, 2009).

No mundo todo, 5,7 bilhões de pessoas utilizam água potável a partir de fontes melhoradas; 3,6 bilhões utilizam uma conexão de água encanada e 884 
milhões ainda não têm acesso a fontes de água adequada, principalmente nos países em desenvolvimento (WORLD HEALTH ORGANIZATION; UNITED NATIONS CHILDREN'S FUND (WHO; UNICEF), 2010).

Os números também revelam grande disparidade quando comparado o acesso à água potável segura, nas áreas urbanas e rurais. Do total da população mundial, $87 \%$ das pessoas que recebem água potável de fontes melhoradas, vivem em áreas urbanas, sendo este número 5 vezes maior do que o referente para a população das áreas rurais (WHO; UNICEF, 2010).

No período de 1990 a 2008, cerca de 1,8 milhões de pessoas passaram a ter acesso à água potável de qualidade; deste total, 59\% vivem em áreas urbanas. Em relação aos serviços de saneamento, os números revelam a baixa cobertura do setor, sendo que 2,5 bilhões de pessoas não têm acesso à estrutura de saneamento, destacando que, deste total, 1,2 bilhões não possuem as instalações domésticas para este fim (WHO; UNICEF, 2010).

Durante as últimas décadas, houve um aumento na cobertura dos sistemas de abastecimento de água potável e saneamento, em todas as regiões do planeta. Na América Latina e no Caribe, em 1990, 67\% da população recebia água encanada através de instalações domésticas, e em 2006 , este número subiu para $80 \%$. Com relação ao saneamento, $68 \%$ da população tinha acesso aos serviços em 1990, passando a $79 \%$ no ano de 2006 (WHO; UNICEF, 2008).

No Brasil, com relação aos serviços de saneamento (água, esgotamento sanitário e resíduos sólidos), as perspectivas são animadoras, conforme revelam os resultados obtidos pela Pesquisa Nacional por Amostra de Domicílios (PNAD) e divulgados pelo Instituto de Pesquisa Econômica Aplicada (IPEA, 2008).

De acordo com informações da PNAD, a rede de abastecimento de água aumentou 0,7 pontos percentuais entre 2007 e 2008, atendendo cerca de 1,8 milhões de casas a mais no período.

O maior aumento ocorreu na região Nordeste, onde atualmente, 78\% das residências recebem água proveniente da rede de distribuição. No entanto, 
na região Norte, apenas 58,3\% das casas estão conectadas ao sistema de abastecimento e na região encontram-se os três estados com as redes mais precárias: Rondônia, Pará e Acre, que atendem 42,3\%, 49,1\% e 56,8\% dos domicílios, respectivamente (INSTITUTO BRASILEIRO DE GEOGRAFIA E ESTATÍSTICA (IBGE), 2009).

O acesso à água potável, através da rede geral de abastecimento, tem beneficiado 91,3\% dos moradores de domicílios urbanos (Figura 1) e 23,8\% da população em zonas rurais segundo os dados revelados pela PNAD.

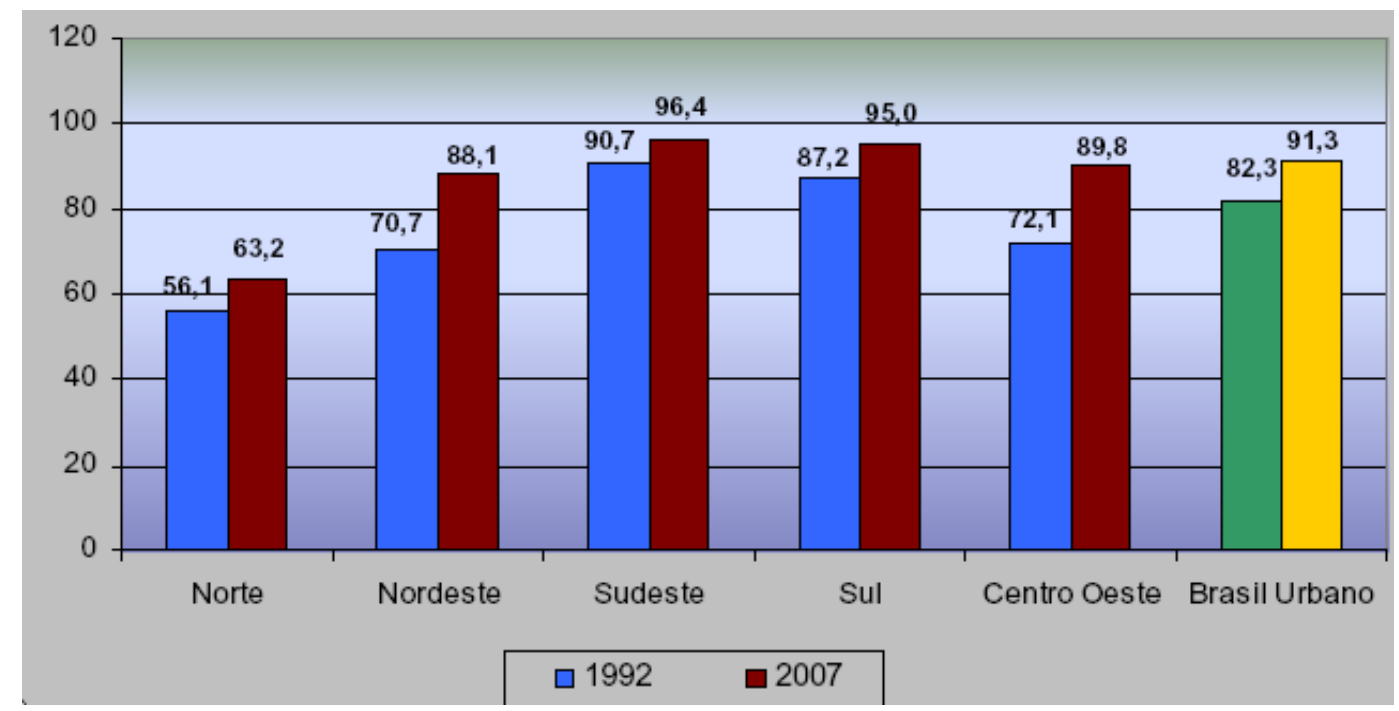

Figura 1 - Percentual de moradores em domicílios particulares permanentes urbanos com acesso à água canalizada de rede geral, segundo regiões geográficas. Fonte: IPEA (2008).

Com relação ao esgotamento sanitário, a PNAD revelou que 57,4\% da população urbana do país dispõe desse serviço (Figura 2), número que chega a quase $81 \%$ considerando-se também a população urbana que possui coleta de esgoto por fossa séptica. 


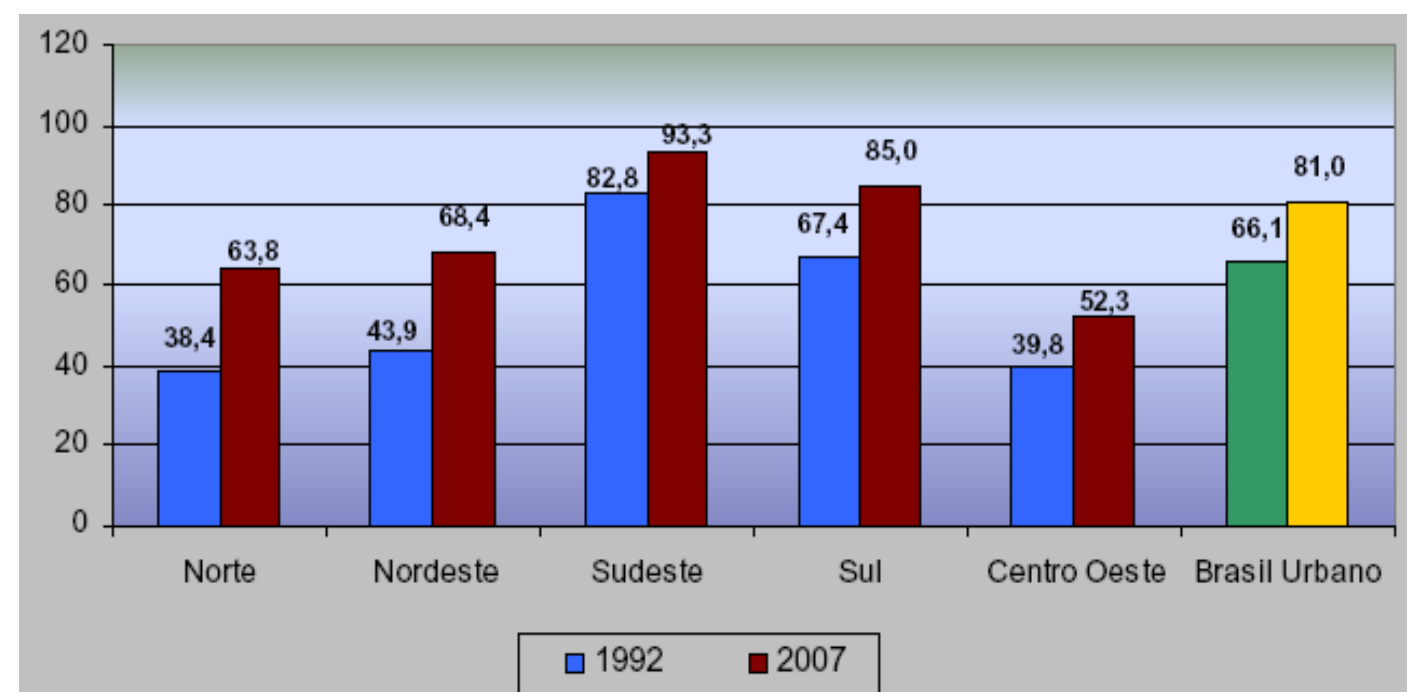

Figura 2 - Percentual de pessoas em domicílios particulares permanentes urbanos com esgotamento por rede coletora ou fossa séptica, segundo as regiões geográficas. Fonte: IPEA (2008).

Assim como verificado no caso de abastecimento de água, existem grandes diferenças da cobertura de esgotamento sanitário, nas áreas urbanas e rurais; $22 \%$ da população que vive em áreas rurais reside em domicílios que não possuem nenhum tipo de sistema de coleta de esgoto e 54,3\% recorre a medidas não adequadas para a coleta de esgoto, como fossas rudimentares e despejo direto em rios e lagos (IPEA, 2008).

Somente nas áreas urbanas, 30 milhões de pessoas residem em domicílios que não dispõe de sistema de coleta e tratamento de esgoto; tal fato ainda representa um desafio para as políticas de saneamento. Apesar das melhorias e aumento significativo de cobertura do setor, as áreas rurais ainda carecem de infraestrutura básica para proporcionar uma melhoria na qualidade de vida da população, evitando-se principalmente a veiculação de doenças de origem hídrica através do descarte inadequado do esgoto doméstico (IPEA, 2008). 


\section{2 Água destinada ao consumo humano e padrões de potabilidade}

Os padrões universais para o controle da qualidade da água destinada ao abastecimento público são recomendados pelo "Guidelines for DrinkingWater Quality" da World Health Organization (WHO, 2008), estabelecendo valores máximos permissíveis para agentes microbiológicos e químicos presentes na água. Na Austrália os padrões são estabelecidos pelo Australian Drinking Water Guidelines (ADWG), nos Estados Unidos segue-se o Drinking Water Guidelines da Environmental Protection Agency (EPA) e para os países da União Européia criou-se o Directive 98/83/EC (RAJARATNAM; WINDER; AN, 2002; CLASEN; BASTABLE, 2003).

No Brasil, a água destinada ao consumo humano denomina-se potável e deve preencher condições mínimas de acordo com padrões estabelecidos pela Portaria do Ministério da Saúde, № 518 de 2004, que determina os procedimentos e responsabilidades relativas ao controle e vigilância da qualidade da água para o consumo humano e seu padrão de potabilidade (BRASIL, 2004).

Os critérios adotados para assegurar essa qualidade têm por objetivo fornecer uma base para o desenvolvimento de ações que, se adequadamente implementadas junto às populações, garantirão a segurança do fornecimento de água através da eliminação ou redução à concentração mínima de constituintes na água conhecidos por serem perigosos à saúde (D'AGUILA et al.; 2000).

Os programas de monitoramento e sistemas de informação fundamentam a tomada de decisões para a redução da morbidade decorrente, principalmente de doenças diarréicas de veiculação hídrica, visando a melhoria do sistema de vigilância sanitária e a qualificação das redes de abastecimento de água (D'AGUILA et al., 2000).

Sistemas de informações em saúde foram criados e passaram, nas últimas décadas, por processos de melhoria de qualidade, possibilitando uma sistematização confiável da coleta e organização de dados sobre as condições 
ambientais, como exemplo, pode-se citar o Sistema de Informação do Programa de Vigilância da Qualidade da Água para Consumo Humano (SISAGUA), o qual permite a recuperação de dados sobre a qualidade da água, incluindo as chamadas soluções alternativas de abastecimento (BARCELLOS; QUITÉRIO, 2006).

Em 2009, com a reorganização do Ministério da Saúde, definida no Decreto 6.860, a Coordenação Geral de Vigilância em Saúde Ambiental (CGVAM) e a Coordenação Geral de Saúde do Trabalhador (CGSAT) foram reunidas no Departamento de Vigilância em Saúde Ambiental e Saúde do Trabalhador, na Secretaria de Vigilância em Saúde (DIAS et al., 2009).

A CGVAM tem como atribuições propor, recomendar e adotar medidas de promoção e prevenção a saúde, vigilância de fatores ambientais que interferem na saúde humana, contribuindo com a atenção integral e qualidade de vida da população. A CGVAM está estrutura com as seguintes áreas técnicas:

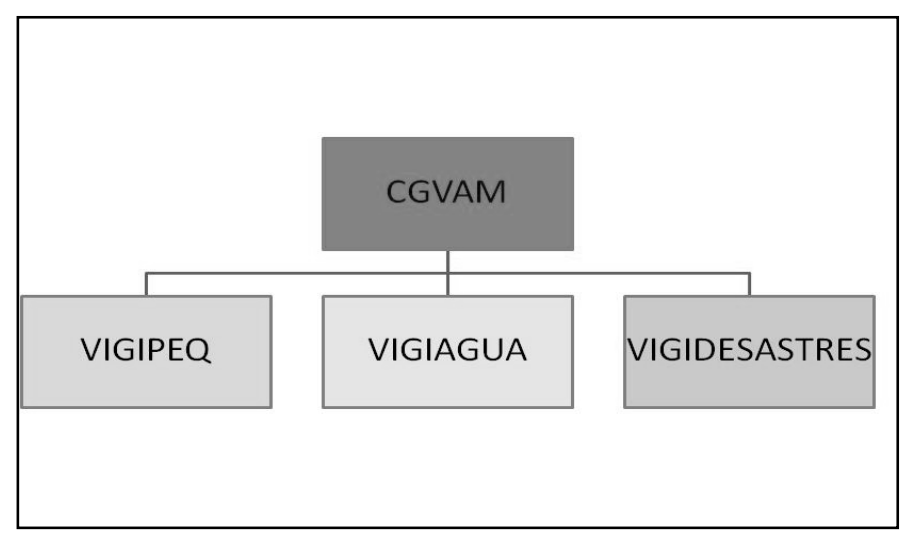

O VIGIPEQ reúne três áreas técnicas: Vigisolo, Vigiquim e Vigiar, que tratam da vigilância em saúde ambiental relacionada a solo contaminado, substâncias químicas e qualidade do ar, respectivamente. O VIGIDESASTRES tem como objetivo a vigilância em saúde ambiental relacionada aos riscos 
ambientais decorrentes de desastres naturais, como enchentes, secas, incêndios florestais, deslizamentos, tornados, etc (BRASIL, 2003).

O VIGIAGUA é um programa que tem por finalidade a efetiva implantação do monitoramento da qualidade da água para consumo humano, por parte das 3 esferas governamentais (municipal, estadual e federal) objetivando desenvolver ações de vigilância em saúde ambiental relacionadas ao acesso à água para consumo humano, em quantidade e qualidade satisfatórias, de acordo com o estabelecido pela legislação vigente (BRASIL, 2003).

Este programa foi concebido de forma abrangente, tendo em vista a sua execução descentralizada, conforme preconizado pelas diretrizes do Sistema Único de Saúde (SUS), respeitando as peculiaridades político-administrativas e diferenças sociais, econômicas e culturais do país (BRASIL, 2003).

Visando a avaliação da qualidade da água de abastecimento, foram desenvolvidas tecnologias para monitoramento de água em municípios abrangidos pelo SUS. Isto se justifica diante dos índices de morbi-mortalidade, referentes às enfermidades de veiculação hídrica, divulgados pela Organização Mundial da Saúde (OMS)

O SUS é um dos maiores sistemas públicos de saúde do mundo, abrangendo desde o atendimento ambulatorial até o transplante de órgãos, garantindo acesso integral, universal e gratuito para toda a população brasileira. Foi criado em 1988, pela Constituição Federal Brasileira, amparado num conceito ampliado de saúde (BRASIL, 2009). Além de oferecer consultas, exames e internações, o Sistema promove campanhas de vacinação e ações de vigilância sanitária, como a fiscalização de alimentos e registros de medicamentos.

A estrutura física de atendimento aos usuários do SUS compõe Unidades de Atenção Básica, as quais são gerenciadas com prioridade na gestão do Sistema, pois ao funcionarem adequadamente, a população consegue resolver, com qualidade, a maioria dos seus problemas de saúde. 
As unidades podem variar em sua formatação, adequando-se às necessidades de cada região. Podem ser: unidade de saúde da família; posto de saúde; centro de saúde/unidade básica de saúde; unidade móvel fluvial; unidade terrestre móvel; unidade mista e ambulatórios de unidade hospitalar geral (BRASIL, 2009). O centro de saúde/unidade básica de saúde destina-se à realização de atendimentos de atenção básica e integral a uma população, de forma programada ou não, nas especialidades básicas, podendo oferecer assistência odontológica e de outros profissionais de nível superior.

Os serviços de saúde, a partir dos princípios e diretrizes do SUS, diante de uma rede hierarquizada, fundamentam-se nas unidades locais, onde em conjunto com a população atendida abordam as questões de saúde, na sua integralidade, tais como: habitação, lazer, educação, segurança, saneamento ambiental, etc (FORTUNA, 1999).

Diante do contexto apresentado, acreditamos que a vigilância da qualidade da água para consumo humano deve ser uma atividade rotineira, de ação preventiva, com a finalidade de garantir o consumo de água de qualidade, minimizando as possibilidades de transmissão de uma série de enfermidades à população; esta ação pode ser desenvolvida entre a comunidade e os profissionais das unidades básicas de saúde.

\section{3 Água e sua relação com a saúde pública}

Desde 1990, mais de 1,6 bilhões de pessoas têm acesso à água potável em todos os continentes. Espera-se alcançar uma taxa de cobertura para $89 \%$ da população que vive em regiões em desenvolvimento, até o ano de 2015 (ONU, 2008).

Segundo dados da Organização das Nações Unidas (ONU), o progresso em relação ao acesso a água potável tem sido mais pronunciado no Leste da Ásia, onde mais de 40 milhões de pessoas passaram a consumir água de fontes apropriadas, estendendo a cobertura em $20 \%$ desde 1990. Na África 
Sub Saariana, foram registrados os menores índices de acesso; atualmente esta região responde por mais de $1 / 3$ das pessoas sem abastecimento de água.

O déficit de acesso à água é uma realidade também para as regiões em desenvolvimento; em 2006, as fontes de água de qualidade estavam disponíveis para $96 \%$ da população urbana mundial, enquanto que apenas $78 \%$ da população vivendo em áreas rurais tinham acesso à água potável, reforçando a disparidade entre os centros urbanos e área rural, locais em que somente $30 \%$ das casas estão conectadas ao sistema de abastecimento de água.

Para a América Latina e Caribe, os dados revelam que houve um aumento na proporção da população com acesso à água proveniente de fontes adequadas, passando de $89 \%$ no ano de 2000, para 92\% em 2006.

No Brasil, o acesso à água está condicionado a fatores sociais, econômicos e geográficos; na Amazônia, região que apresenta baixa densidade populacional, encontra-se $78 \%$ da água superficial do país, ao contrário da região Sudeste, a de maior densidade do país, dispõe apenas de $6 \%$ do total de água disponível para consumo humano.

Nas cidades, os problemas de abastecimento estão diretamente relacionados ao crescimento da demanda, ao desperdício e à urbanização descontrolada, fatores que atingem regiões de mananciais. $\mathrm{Na}$ zona rural, os recursos hídricos também são explorados de forma irregular, além de parte da vegetação protetora da bacia hidrográfica (mata ciliar) ser destruída para a realização de atividades como agricultura e pecuária.

A OMS considera que o acesso à água potável é um dos principais fatores que podem influenciar positivamente na qualidade e expectativa de vida das populações que vivem nos países em desenvolvimento (WHO, 2008), além de representar um direito humano fundamental e uma condição básica para a promoção da saúde em escala global (KORFALI; JURDI, 2009).

O conceito de Promoção de Saúde proposto pela Organização Mundial de Saúde, desde a Conferência de Ottawa, em 1986, é visto como o princípio 
orientador das ações de saúde em todo o mundo. Assim sendo, parte-se do pressuposto de que um dos mais importantes fatores determinantes da saúde são as condições ambientais. O conceito de saúde entendido como um estado de completo bem-estar físico, mental e social, não restringe o problema sanitário ao âmbito das doenças.

Atualmente, além das ações de prevenção e assistência, considera-se cada vez mais importante atuar sobre os fatores determinantes da saúde. A maioria dos problemas sanitários que afetam a população mundial estão intrinsecamente relacionados ao meio ambiente; um exemplo disso é a diarréia que com mais de quatro bilhões de casos por ano, é uma doença que aflige a humanidade. Entre as causas dessa doença destacam-se as condições inadequadas de saneamento (BRASIL, 2006).

As intervenções direcionadas à implementação de sistemas de abastecimento de água, coleta e tratamento das águas residuárias, aliadas às ações educativas de higiene, são exemplos de decisões governamentais importantes para a melhoria da qualidade de vida nos países em desenvolvimento. Ao proporcionar o acesso à água potável e instalações sanitárias, promovem-se condições de saúde adequada, melhorando diretamente a renda salarial, a escolaridade e a igualdade de gêneros da população (ONU, 2008)

Um dos 'Objetivos do Milênio' é reduzir pela metade o número de pessoas sem acesso ao abastecimento de água adequada até o final de 2015. A OMS e a UNICEF defendem a meta de água e saneamento para todos até o final de 2025; isto significa afirmar que aproximadamente 2,9 bilhões de pessoas serão atendidas com a melhoria do sistema de abastecimento de água e 4,2 bilhões com o saneamento ambiental (ONU, 2008).

O risco à saúde pública está associado aos fatores possíveis e indesejáveis de ocorrerem em áreas urbanas e rurais, os quais podem ser minimizados ou eliminados com o uso apropriado de serviços de saneamento ambiental. O fornecimento de água potável é entendido como uma fonte de 
alimento seguro à população e o sistema de esgoto é capaz de promover a interrupção de uma via de contaminação humana (BRASIL, 2006).

Com os avanços nas tecnologias, a água bruta de qualquer qualidade pode ser tratada pelas Estações de Tratamento de Água (ETAs), que são responsáveis pela captação de água subterrânea ou de mananciais, por meio de bombas, as quais realizam a condução da água através das adutoras até as estações de tratamento, local onde a água, após receber adequado tratamento, torna-se apropriada para consumo humano (GOHRINGER, 2006).

Na Figura 3 estão representados os processos realizados em uma ETA, do início, com a chegada da água bruta, até a finalização, com a saída da água tratada e pronta para o consumo (BRASIL, 2006).

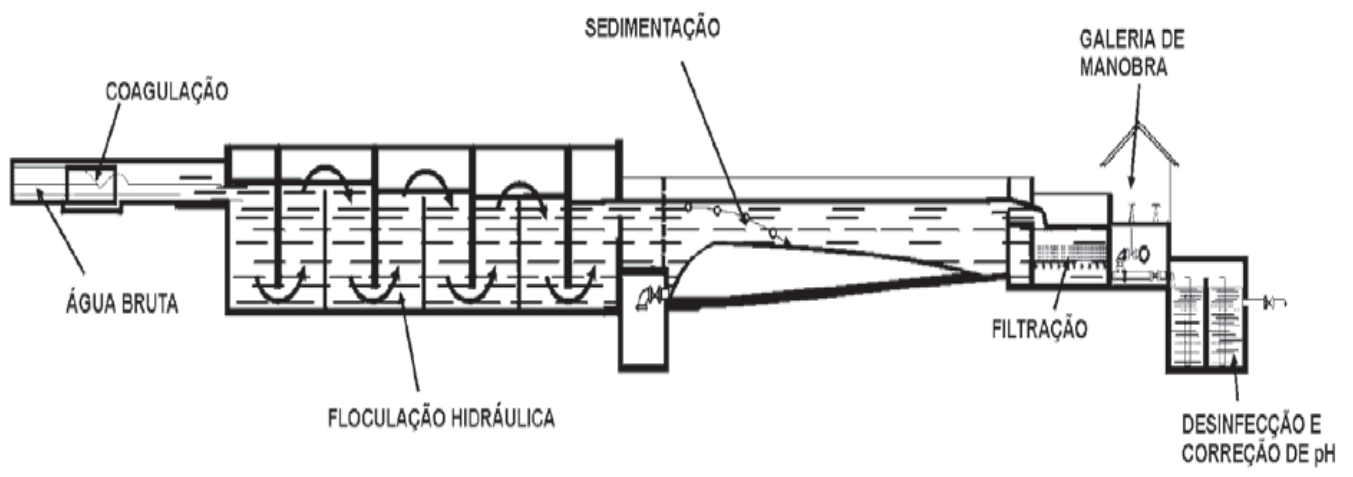

Figura 3 - Representação gráfica da sequência do tratamento convencional de água em uma ETA. Fonte: Brasil, 2006.

A seguir, destacam-se os processos realizados durante o tratamento convencional da água, a fim de torná-la apropriada ao consumo humano, segundo o Manual de Saneamento, elaborado pela Fundação Nacional de Saúde - FUNASA (BRASIL, 2006).

O tratamento da água pode ser parcial ou completo, de acordo com a análise prévia de suas características físicas, químicas e biológicas. $O$ tratamento coletivo é efetuado na ETA, onde passa por diversos processos de depuração: 


\section{$\checkmark$ Clarificação}

A etapa de clarificação constitui-se de um conjunto de operações unitárias, destinadas à remoção de sólidos. A clarificação, cuja função essencial consiste na remoção da turbidez, apresenta uma grande importância no tratamento de águas de abastecimento, proporcional à importância do parâmetro turbidez na potabilidade da água.

\section{$\checkmark$ Coagulação}

Operação na qual é realizada a desestabilização dos colóides (partículas sólidas minúsculas) presentes na água, permitindo assim que eles posteriormente se aglutinem, formando flocos, passíveis de serem separados na sedimentação ou na filtração. Nesta etapa, utiliza-se um produto químico (coagulante) para agregar as partículas; o mais utilizado é o sulfato de alumínio.

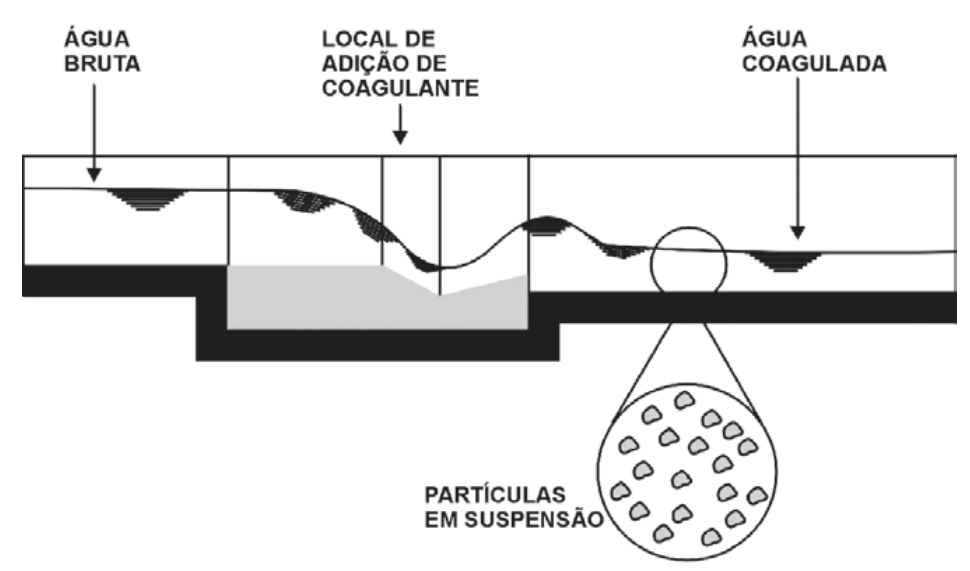

Figura 4 - Representação gráfica do processo de coagulação. Fonte: Brasil, 2006.

\section{$\checkmark$ Floculação}

Formação de flocos, mediante a introdução de energia na massa líquida, capaz de favorecer o contato entre os colóides desestabilizados e permitir a sua aglutinação. 


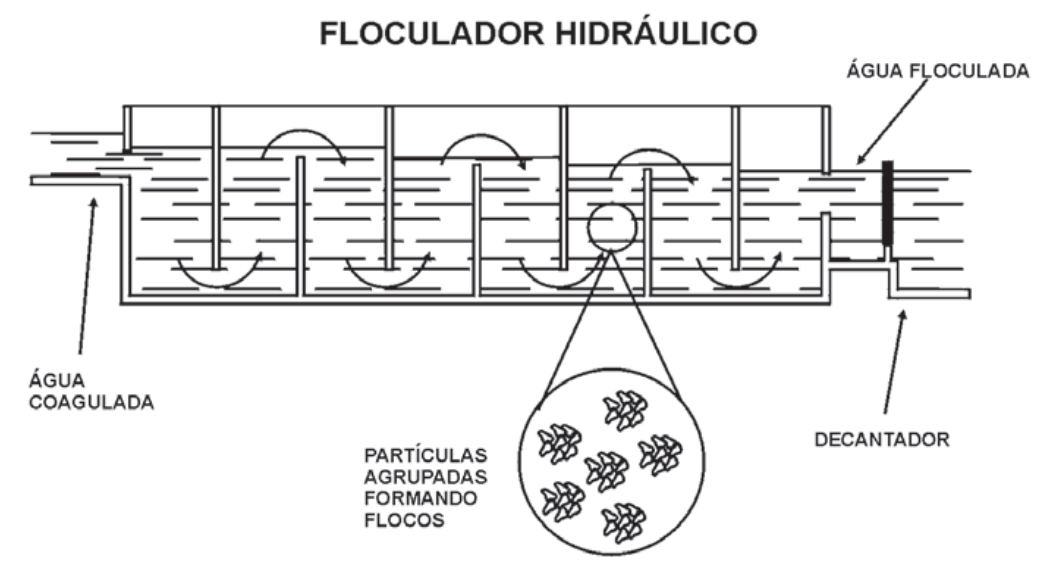

Figura 5 - Representação gráfica do processo de floculação. Fonte: Brasil, 2006.

\section{$\checkmark$ Sedimentação}

Separação dos sólidos da água, pela ação da gravidade, após a coagulação e a formação de agregados (floculação). Este processo é de extrema importância para que a filtração possa remover o restante do material sólido.

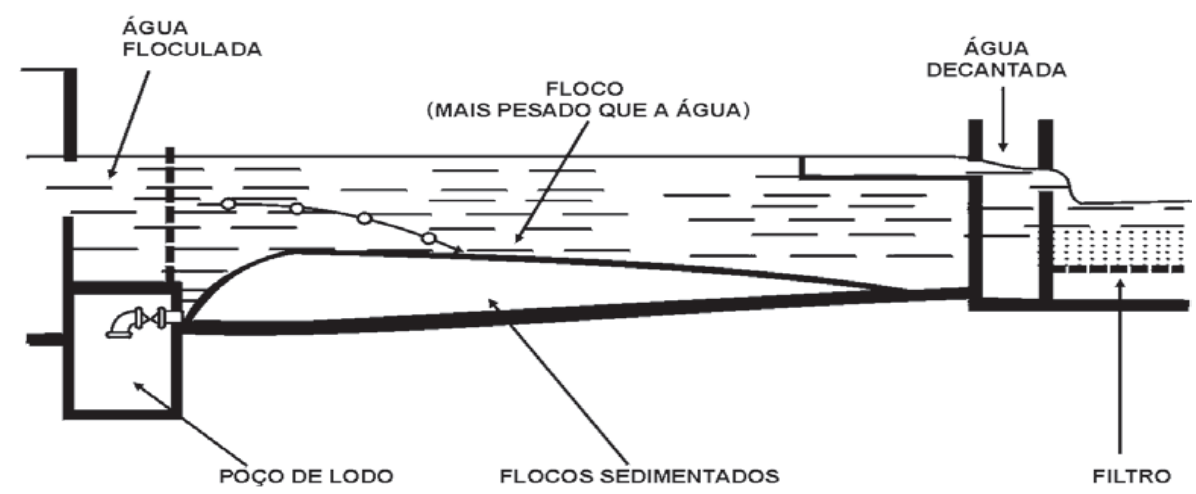

Figura 6 - Representação gráfica do processo de sedimentação.Fonte: Brasil, 2006.

\section{$\checkmark$ Filtração}

Passagem da água por um leito de material granular, através do qual ocorre a separação das partículas presentes na água. São classificados, em 
função do sentido do fluxo, em descendentes ou ascendentes, e, em função da velocidade de filtração, em rápidos (120 a $360 \mathrm{~m}^{3} / \mathrm{m}^{2}$.d) ou lentos (3 a 14 $\left.\mathrm{m}^{3} / \mathrm{m}^{2} . \mathrm{d}\right)$. Algumas modalidades e importantes características dos processos de filtração são:

\section{a) Pré-filtro}

Utilizado como pré-tratamento para a filtração lenta, alivia essa unidade de algumas impurezas, especialmente sólidas. No pré-filtro ocorre também remoção da carga bacteriológica da água bruta, já que parte dos organismos é removida.

b) Filtração lenta

O tratamento através de filtro lento constitui uma solução bastante simples, do ponto de vista operacional, em muitos casos se limitando à existência dos próprios filtros, sem instalações para manuseio de produtos químicos. No filtro lento, as baixas taxas de filtração determinam um desempenho bastante diferente daquele característico dos filtros rápidos. Ao contrário desses, a camada superficial do filtro é a responsável por praticamente todo o mecanismo de filtração. Na superfície do leito, a baixa taxa de aplicação permite a formação de uma camada biológica gelatinosa, constituída por bactérias, algas e plâncton em geral, capaz de exercer uma eficiente função bactericida. Fisicamente, o filtro é constituído de um tanque, onde é colocada uma camada de areia fina, com espessura entre 0,90 e 1,20 $\mathrm{m}$, sobre uma camada de cascalho, com espessura entre 0,20 e 0,45 m. Sob a camada de cascalho, é previsto um sistema de drenagem, para recolhimento da água filtrada. 


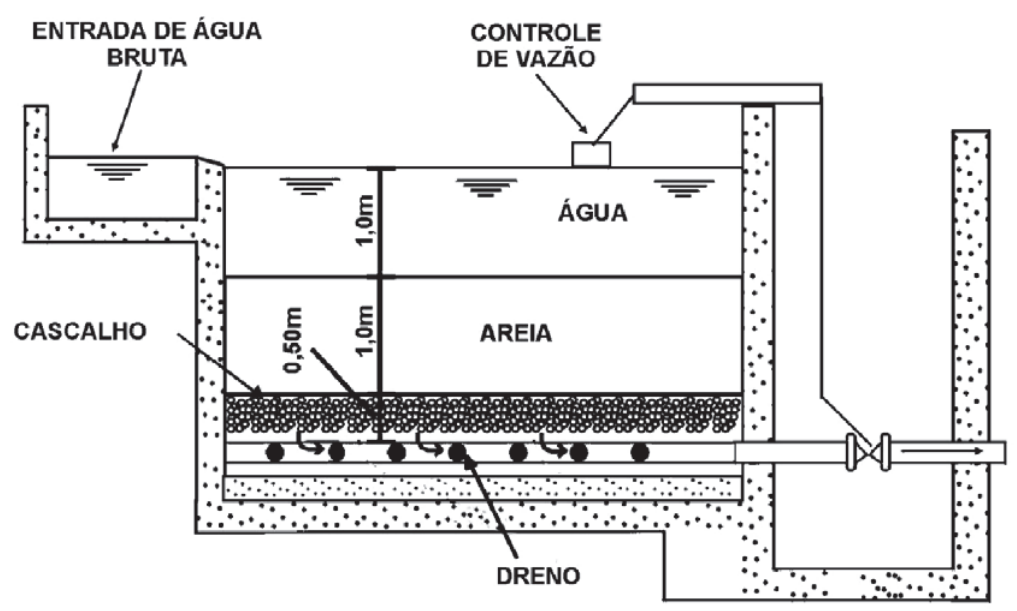

Figura 7 - Representação gráfica do processo de filtração lenta. Fonte: Brasil, 2006.

c) Filtração rápida

Os filtros rápidos (taxa de filtração entre 120 e $360 \mathrm{~m}^{3} / \mathrm{m}^{2} . \mathrm{d}$ ) surgiram da necessidade de uma maior vazão para o atendimento de grandes cidades. Para estas cidades, o filtro lento ocuparia áreas muito grandes. Os processos de clarificação que antecedem a filtração rápida permitem o aproveitamento de águas superficiais menos resguardadas e mais próximas do centro de consumo. Ao mesmo tempo, os filtros rápidos exigem maior controle operacional e pessoal mais qualificado. Na filtração rápida, a retenção das impurezas ocupa o meio filtrante ao longo de toda a sua profundidade, não concentrando-se apenas no topo, como na filtração lenta.

Do ponto de vista do comportamento hidráulico, essas unidades podem ser classificadas em: filtração de fluxo descendente ou filtração de fluxo ascendente.

Na filtração de fluxo descendente, a água percorre a camada filtrante de cima para baixo, e do material mais fino para o material mais grosso. A lavagem do filtro é feita em intervalos de 20 a 40 horas, dependendo das características da água que chega ao filtro e das condições de operação, em contracorrente, por inversão de fluxo (isto é, de baixo para cima). A camada suporte, sobre a qual é colocado o leito filtrante, tem em média $0,45 \mathrm{~m}$ de 
espessura, e a camada filtrante de 0,40 a $0,70 \mathrm{~m}$. A altura total da caixa do filtro varia de 3,0 a 5,0 metros.

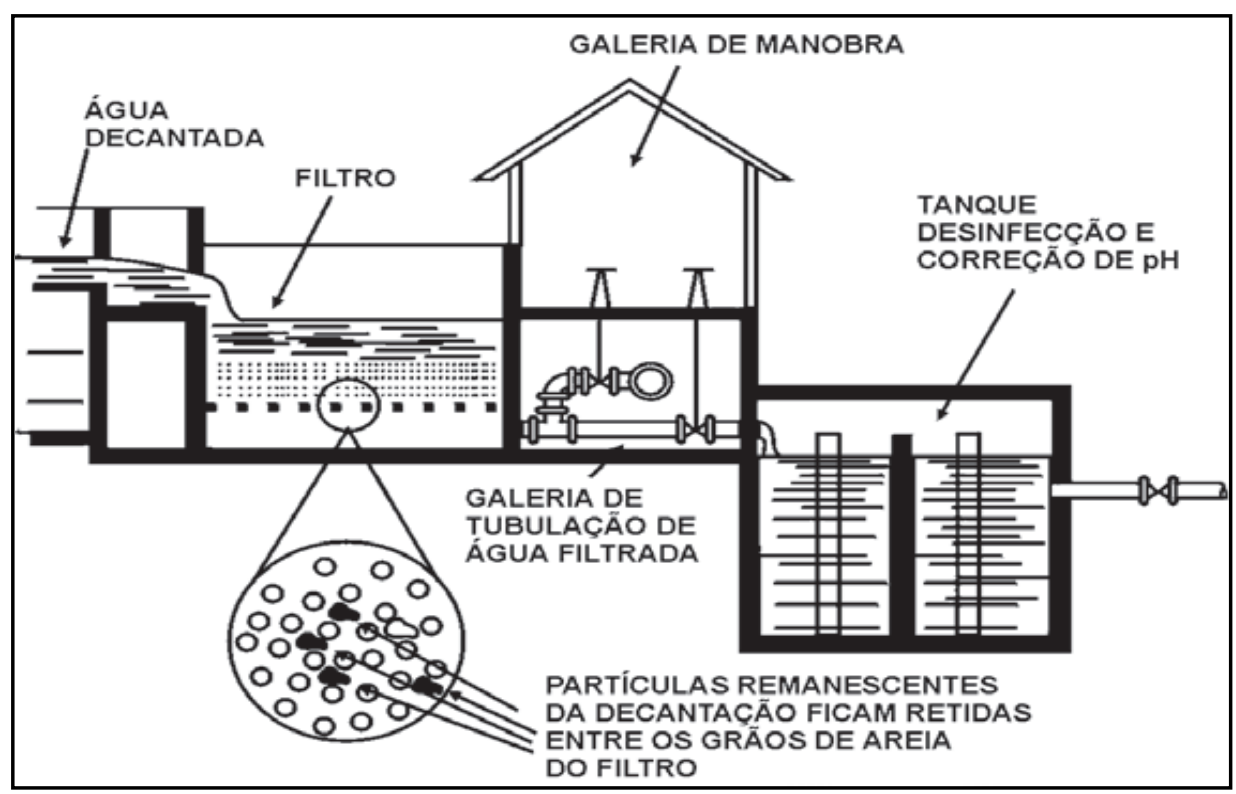

Figura 8 - Representação gráfica do processo de filtração rápida descendente. Fonte: Brasil, 2006.

Na filtração de fluxo ascendente o sentido é inverso (fluxo de baixo para cima). Dispensa a floculação e a decantação, sendo aplicado um coagulante alguns minutos antes da filtração. O fluxo de água encontra um material mais grosseiro nas camadas inferiores do meio filtrante e material mais fino na parte superior. A lavagem é feita com uma corrente de água no mesmo sentido da filtração. A água filtrada recebe um desinfetante antes de sua distribuição. É aplicável para água bruta de baixa turbidez, pouco poluída, e que não passe por variações bruscas de qualidade.

\section{$\checkmark$ Desinfecção}

Processo aplicado ao final do tratamento para a eliminação de microrganismos patogênicos. A adição de cloro é o processo mais tradicional e econômico, utilizado nas ETAs. 
O cloro é aplicado na água por meio de dosadores, que são aparelhos que regulam a quantidade do produto a ser ministrado, dando-lhe vazão constante. Pode ser aplicado sob a forma gasosa e nesse caso, usam-se dosadores de diversos tipos. O acondicionamento do cloro gasoso é feito em cilindros de aço, com várias capacidades de armazenamento.

Pode ainda ser aplicado sob a forma líquida, proveniente de diversos produtos que libertam cloro quando dissolvidos na água e os aparelhos usados nesse caso são os hipocloradores e as bombas dosadoras.

\section{$\checkmark$ Fluoretação}

Com a descoberta da importância dos sais de flúor na prevenção da cárie dental, quando aplicados aos indivíduos na idade suscetível, isto é, até aos 14 anos de idade, e em ordem decrescente de efetividade à medida que aumenta a idade da criança, generalizou-se a técnica de fluoretação de abastecimento público como meio mais eficaz e econômico de controle da cárie dental.

As aplicações no abastecimento de água fazem-se por meio de aparelhos dosadores, sendo usados o fluoreto de sódio, o fluossilicato de sódio e o ácido fluossilícico.

\section{$\checkmark$ Armazenamento}

Os reservatórios representam, normalmente, o ponto frágil de um sistema de distribuição de água. Para evitar sua contaminação, é necessário que sejam protegidos com estrutura adequada, tubo de ventilação, impermeabilização, cobertura, sistema de drenagem, abertura para limpeza, registro de descarga, ladrão e indicador de nível.

\section{$\checkmark$ Controle de qualidade do processo de tratamento}

O laboratório da ETA, ou empresa responsável pelo abastecimento de água, realiza exames físico-químicos e bacteriológicos destinados à avaliação da qualidade de água desde o manancial até o sistema de distribuição. Além 
disso, realiza análises específicas como: identificação de resíduos de pesticidas e metais pesados. Esses exames são feitos na água bruta, durante o tratamento e em pontos da rede de distribuição, de acordo com o que estabelece a legislação em vigor.

A seguir, um esquema ilustra os processos realizados com a água, desde a captação até a distribuição para a rede de abastecimento (Figura 9).

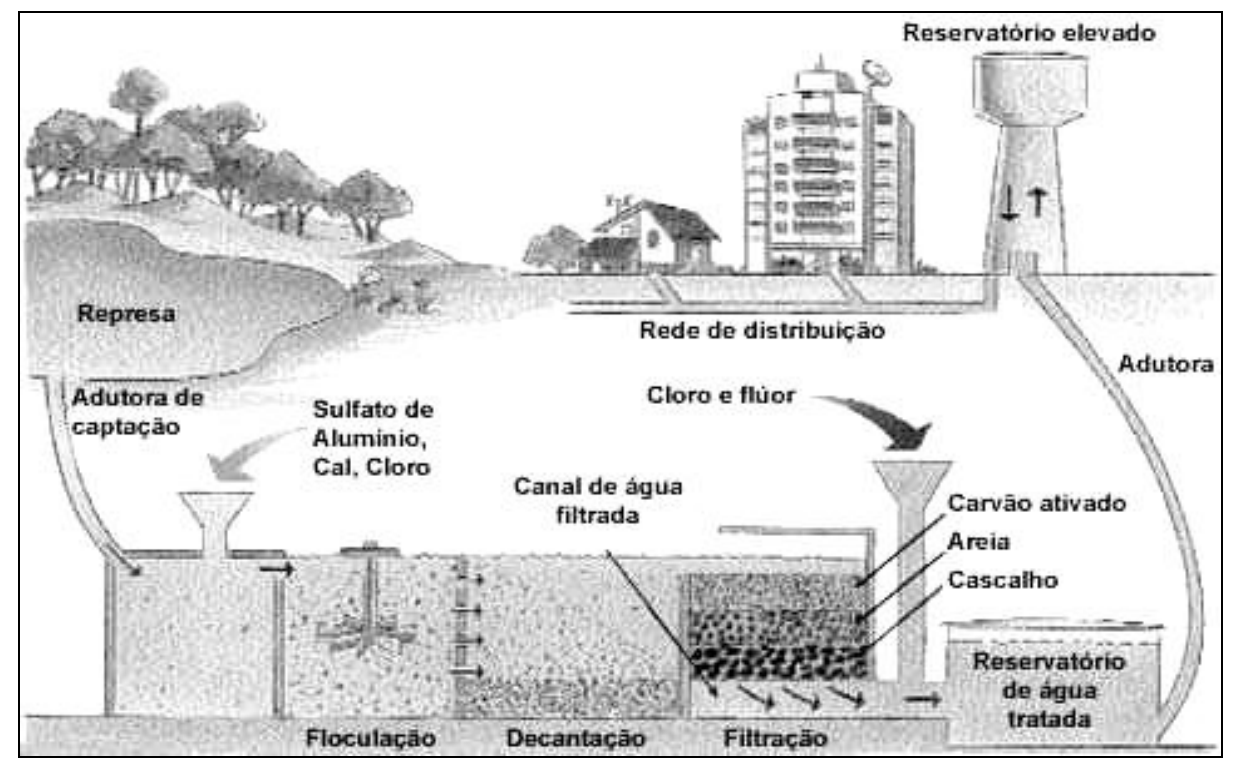

Figura 9 - Fluxograma de uma ETA - captação de água superficial. Fonte: universidade net.

A água pode ser captada de mananciais superficiais e subterrâneos. As águas subterrâneas são as principais fontes de água potável nas regiões com déficit de água superficial ou em localidades sem sistema centralizado de abastecimento de água.

Em muitos locais a água subterrânea é um complemento das superficiais, sendo muitas vezes consumida indiscriminadamente pela população, como parte de um sistema alternativo de abastecimento, o qual não está sob responsabilidade de empresas de saneamento. Frequentemente são 
perfurados poços domésticos, sem considerar a qualidade da água, a qual poderá interferir no bem-estar dos consumidores (MIRLEAN et al., 2005).

Geralmente os problemas com a qualidade da água subterrânea são maiores em regiões rurais devido à infiltração de agrotóxicos, fertilizantes, esgotos domésticos e excrementos de animais nos aqüíferos ou, diretamente, nos poços artesianos. Nessas regiões, os efeitos são mais significativos em seus consumidores devido à ausência de outras opções de abastecimento. Entretanto, nas zonas industriais, a preocupação com a qualidade da água subterrânea não é prioritária, visto que a população que reside nessas áreas consome água proveniente de sistema centralizado de água potável (MIRLEAN et al., 2005).

Segundo estimativas, aproximadamente $51 \%$ da água potável consumida pela população brasileira provem de aqüíferos (CONCEIÇÃO et al., 2009), incluindo o Aquífero Guarani, caracterizado como um imenso reservatório hídrico subterrâneo, resultante de diversas formações geológicas. Estende-se pelo território de quatro países (Brasil, Argentina, Uruguai e Paraguai).

No Brasil, o aqüífero se dispersa ao longo de oito Estados da Federação: Mato Grosso do Sul, Rio Grande do Sul, São Paulo, Paraná, Goiás, Minas Gerais, Santa Catarina e Mato Grosso (RIBEIRO, 2008).

No Estado de São Paulo o uso da água subterrânea tem crescido gradativamente. Segundo a Companhia Ambiental do Estado de São Paulo (CETESB), dos 645 municípios paulistas, 72\% são total ou parcialmente abastecidos por esse recurso hídrico e 47\% deles são inteiramente abastecidos por água subterrânea. Entre essas cidades, podemos destacar Catanduva, Caçapava, Ribeirão Preto, Tupã, Jales e Lins (SÃO PAULO, 2007).

Ribeirão Preto, no estado de São Paulo, é uma cidade privilegiada em relação ao saneamento ambiental, sendo que 99,9\% da população têm acesso à água proveniente do sistema de distribuição. Toda a água consumida e distribuída pelo Departamento de Águas e Esgotos de Ribeirão Preto (DAERP) é originária do Aqüífero Guarani. Para retirá-la de uma profundidade de mais 
de 200 metros, são perfurados poços tubulares profundos, conhecidos como poços artesianos; a extração é feita por bombas submersas. O município de Ribeirão Preto possui 103 poços artesianos em funcionamento, responsáveis por $14.050 \mathrm{~m}^{3} / \mathrm{h}$ de água (RIBEIRÃO PRETO, 2009).

Devido à sua origem de poços profundos (Figura 10 A), a água de Ribeirão Preto requer somente a adição de cloro, que é realizada logo após a sua retirada dos poços. A fluoretação (adição de flúor) também é feita nessa fase (Figura 10 B). O flúor na água de abastecimento reduz em cerca de $60 \%$ a incidência de cáries dentárias, sendo o meio mais eficiente e econômico para a sua prevenção. A água clorada e fluoretada é conduzida aos reservatórios através de tubulações, de onde é distribuída para as redes de abastecimento até chegar às residências e serviços de saúde, passando por um hidrômetro, que é o aparelho medidor do consumo de água (RIBEIRÃO PRETO, 2009).

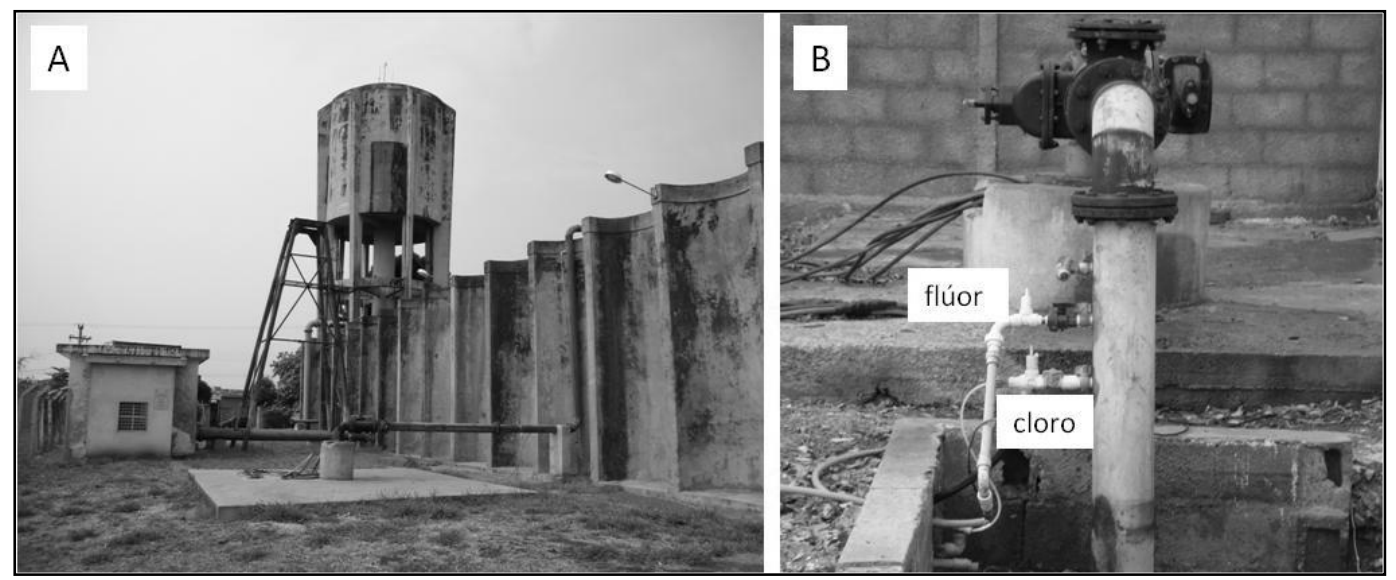

Figura 10 - A) Poço artesiano com reservatório localizado no município de Ribeirão Preto. B) Adição de cloro e flúor na água captada. Fonte: Julião, F.C. (2010).

Os responsáveis pelas empresas de abastecimento de água e qualidade da mesma, não deveriam recorrer somente à cloração como solução universal dos problemas de contaminação devido aos riscos causados pela formação de trihalometanos, que podem ter efeitos negativos sobre a saúde humana. No 
entanto, embora a desinfecção da água possa ser realizada por outros meios (calor, luz ultravioleta, ozônio, dióxido de cloro), a utilização do cloro e seus derivados tem sido a mais difundida em função de sua facilidade de aplicação, menor custo econômico e alta eficiência (MIRANDA, 1989).

A cloração deve ser empregada para resolver problemas de qualidade de água causados por bactérias do grupo coliformes e outros agentes biológicos que não possam ser resolvidos de outra forma, uma vez que se tenha efetuado todos os esforços razoáveis para eliminar a causa básica do problema; nos casos em que as análises de laboratório revelam que a água do sistema de distribuição está contaminada, torna-se necessária a investigação para detectar a causa e adotar medidas corretivas (MIRANDA, 1989).

O controle de qualidade, desde os sistemas produtores (mananciais, captação, tratamento) até os sistemas de distribuição (reservatórios, redes), normalmente é realizado pela empresa de saneamento local, e monitorada pelas Secretarias de Saúde Estaduais, com base nos procedimentos e responsabilidades estabelecidos na Portaria 518/2004 do Ministério da Saúde.

Este monitoramento institui números mínimos de amostras ou planos de amostragem, estabelecidos na referida Portaria, além dos padrões para a água potável restritos ao trecho que se inicia na captação e se encerra nas ligações domiciliares dos consumidores (D’ÁGUILA et al., 2000).

\subsection{Reservatórios domiciliares de água e sua relevância na rede de distribuição de água potável}

Em muitos países é vetado o uso de reservatórios domiciliares de água. $\mathrm{Na}$ Europa e nos Estados Unidos as residências são conectadas às redes de abastecimento público de água e não há reservatórios; processo denominado de Abastecimento Direto, o qual proporciona água de qualidade devido à presença de cloro residual, proveniente da rede de distribuição, em níveis adequados. 
No Brasil, no século XIX, com a finalidade de sanar os problemas e deficiências dos pioneiros sistemas de abastecimento de água, que além de trabalharem apenas durante o dia, nem sempre tinham pressões suficientes para o bombeamento, houve o aumento e a melhoria da qualidade das redes de distribuição de água, e como conseqüência a esse fato, surgiu a necessidade de instalação de caixas d'água para as fontes de abastecimento hídrico (OLIVEIRA, 2004).

A água proveniente das ETAs percorre um longo trajeto até chegar às instalações prediais, através da rede de abastecimento; ficando armazenada em reservatórios de água, habitualmente denominados de caixas d'água, tidos como uma instalação usual nos domicílios, prédios públicos e privados, serviços de saúde e escolas, atuando como instrumento regulador da vazão, promovendo a segurança em relação ao suprimento da quantidade de água potável necessária diariamente; processo denominado Abastecimento Indireto.

Outro sistema de abastecimento existente é o denominado sistema misto (Figura 11), onde alguns pontos de consumo, como a torneira da cozinha, são abastecidos a partir da rede pública e os restantes (chuveiro, vaso sanitário, torneira do banheiro), são abastecidos pela água armazenada no reservatório domiciliar (caixa d’água).

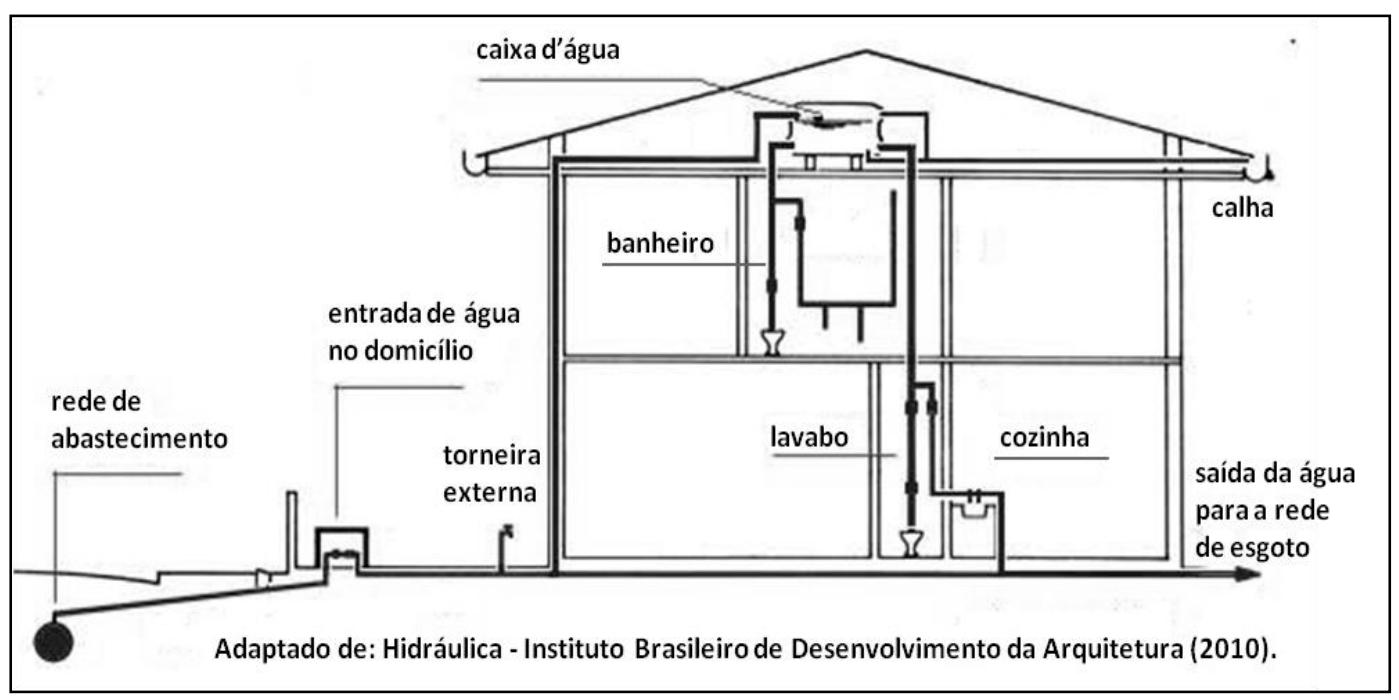

Figura 11 - Representação gráfica da instalação de água nos domicílios com sistema misto. Fonte: Campos, I.M (2007). 
Os reservatórios de água, nas habitações, é considerado parte de todo um sistema de tratamento de água (Figura 12), que deve funcionar em harmonia, não podendo ser considerado como um elemento isolado que, mesmo bem instalado e com acesso fácil estará livre de riscos (MARTONI, 1986).

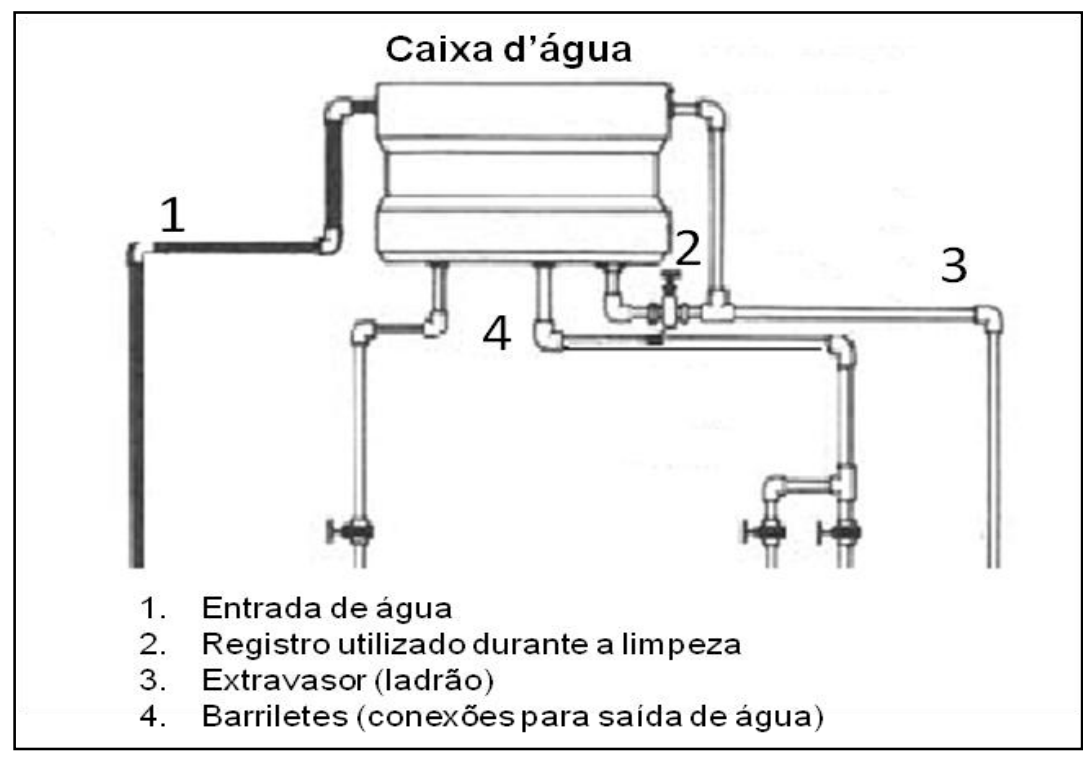

Figura 12 - Representação gráfica da caixa d'água e ramais de distribuição. Fonte: Adaptado de Campos, I.M (2007).

A partir de um estudo realizado no município de Nova Iguaçu - RJ, os pesquisadores concluíram que não se conhece a qualidade da água dos reservatórios domiciliares, pois a água chega tratada do sistema de distribuição, mas no momento do consumo já sofreu algumas alterações durante o tempo em que permaneceu armazenada na caixa d'água, fato que gera grande preocupação no âmbito da saúde coletiva (D'ÁGUILA et al., 2000).

Uma pesquisa realizada em duas regiões no estado do Rio de Janeiro, em 2001, evidenciou que a contaminação da água pode ocorrer no próprio domicílio, por falta de manutenção do reservatório, pela sua localização, pela falta de cuidados com o manuseio e higiene e, também, pelo tipo de material 
que é empregado na construção da caixa d'água, principalmente as mais antigas, fabricadas com amianto (FREITAS; BRILHANTE; ALMEIDA, 2001).

As caixas d'água podem funcionar como um sedimentador de impurezas trazidas pela própria rede de distribuição de água ou, por falta de vedação, proteção e limpeza do reservatório, que geralmente se localiza em locais de difícil acesso, isto é, a matéria orgânica depositada no fundo dos reservatórios pode causar alterações no pH e na cor da água (turbidez), diminuição do teor de oxigênio e cloro residual, além de criar condições para crescimento e proliferação de bactérias, propiciando a formação de um biofilme nas paredes internas do reservatório.

Biofilme é um complexo ecossistema microbiológico e a dinâmica da sua formação ocorre em etapas distintas, iniciando-se com a adesão dos organismos colonizadores a uma superfície, geralmente contendo proteínas ou outros compostos orgânicos. As células aderidas passam a se desenvolver, originando microcolônias que sintetizam uma matriz de polímeros orgânicos que passam a atuar como substrato para a aderência de microrganismos denominados colonizadores secundários, os quais ficarão aderidos diretamente aos primários, ou promoverão a formação de agregados com outros microrganismos e só então ficarão aderidos aos primários (Figura 13). Desta forma, o biofilme corresponde a uma "entidade" dinâmica, pois dependendo dos microrganismos com os quais é composto, apresentará diferentes características físicas, químicas e biológicas (RICKARD et al., 2003). 


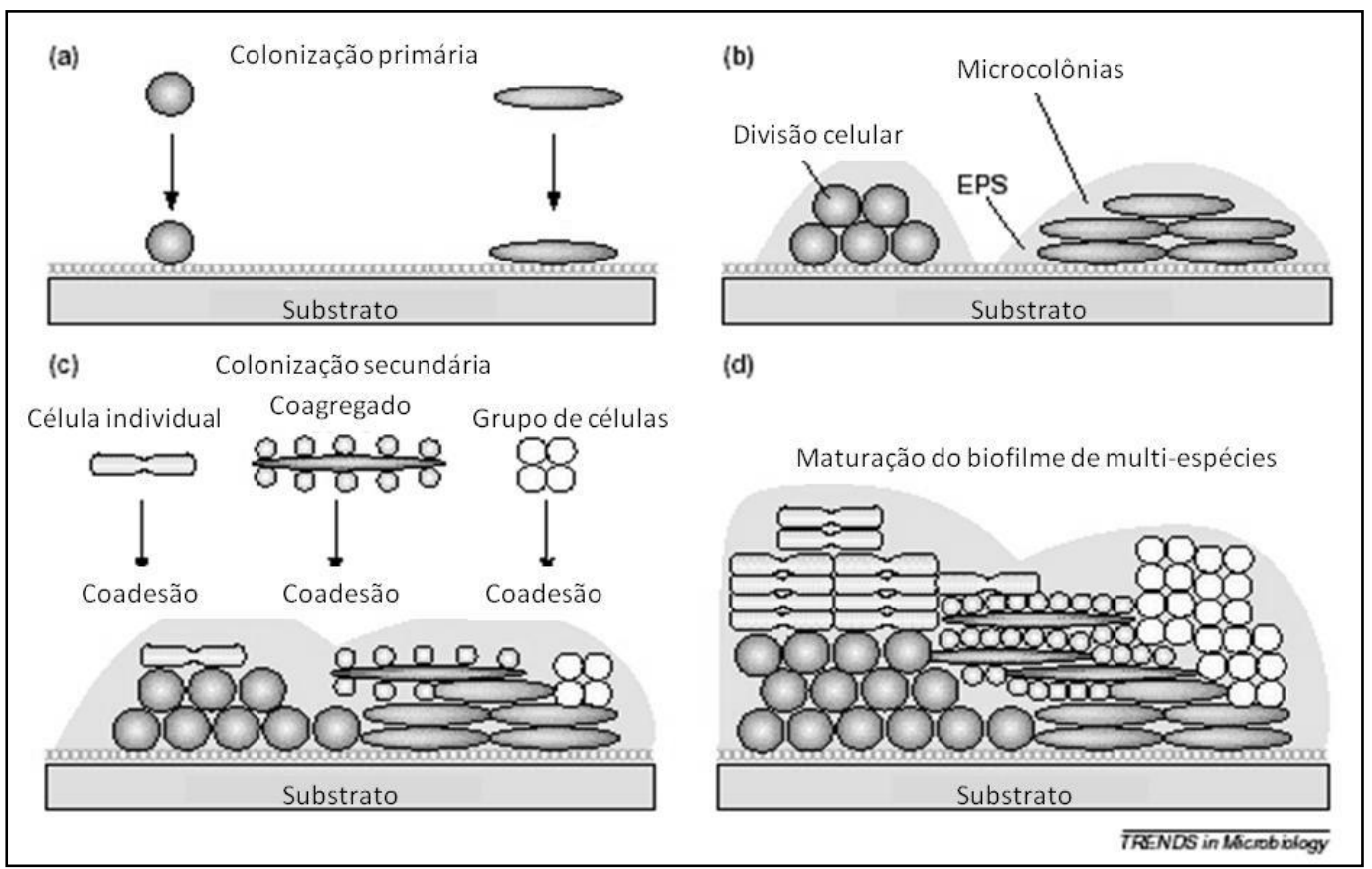

Figura 13 - Representação gráfica do desenvolvimento de um biofilme: a) Colonização primária de um substrato; (b) crescimento, divisão celular, com o desenvolvimento de microcolônias; (c) coadesão de células individuais, de células coagregadas e grupos de células idênticas, originando um biofilme jovem, de múltiplas espécies; (d) maturação e formação de mosaicos clonais no biofilme maduro.Fonte: Adaptado de Rickard et al. (2003).

No biofilme, os microrganismos permanecem mais resistentes à ação de agentes químicos, como aqueles utilizados no processo de higienização, assim, os resíduos aderidos aos equipamentos e superfícies, onde existe um fluxo de água ou outro líquido, transformam-se em potencial fonte de contaminação, permitindo o desenvolvimento de um biofilme. As ações mecânicas são mais eficientes na remoção destes microrganismos, como exemplo, a escovação e remoção dos resíduos de um reservatório doméstico de água para consumo humano (MACEDO, 2000).

Cabe ressaltar que além da falta de manutenção dos reservatórios, com possível degradação da qualidade da água, existe também a contaminação sistemática da rede de abastecimento, proveniente da cloração inadequada e possíveis infiltrações de elementos químicos nas tubulações, como exemplo, os metais tóxicos. 
Os metais presentes na rede de distribuição podem ter origem na variabilidade da qualidade da água que o sistema possa apresentar. Duas origens podem ser indicadas: a primeira diz respeito ao próprio sistema que fornece o metal, principalmente por meio de corrosão química ou microbiológica da rede de distribuição de água; a segunda relaciona-se à origem da água que entra na estação de tratamento, onde principalmente alumínio e ferro formam compostos utilizados no processo de coagulação, cujo objetivo é a remoção de partículas em suspensão na água (FREITAS; BRILHANTE; ALMEIDA, 2001).

Além da própria tubulação e qualidade da água, outro fator que pode influenciar na concentração de metais presente na água destinada ao consumo humano, é a presença de bóias nos reservatórios (equipamento responsável pelo controle da vazão de água nas caixas d’água).

Os resultados dos estudos citados mostraram que em todos os casos ocorre um aumento na quantidade média de patógenos encontrados nos reservatórios em comparação com os encontrados na rede de abastecimento, o que confirma a existência de contaminação da água durante 0 armazenamento.

$\mathrm{Na}$ última década, muitos estudos demonstraram a importância de intervenções sanitárias e educacionais para reduzir a contaminação da água para consumo humano armazenada nas residências, revelando e mensurando os impactos na saúde das populações.

A maioria das pesquisas tem relacionado certas práticas de manejo da água e materiais utilizados na confecção dos recipientes utilizados para armazenamento da água nos domicílios às doenças de veiculação hídrica; além disso, os resultados das investigações têm demonstrado que o período de armazenamento da água nos domicílios, antes do consumo, exerce grande influência no tempo de sobrevivência de bactérias que formam o biofilme em um recipiente (CLASEN; BASTABLE, 2003).

Além da contaminação intra-domiciliar, a qualidade da água tem sido comprometida desde o manancial, pelo lançamento de efluentes e resíduos, 
exigindo investimento nas plantas de tratamento e mudanças na dosagem de produtos para se garantir a qualidade da água na saída das estações.

Verifica-se também que a qualidade da água decai no sistema de distribuição pela intermitência do serviço, pela baixa cobertura da população com sistema público de esgotamento sanitário, pela obsolescência da rede de distribuição, manutenção deficiente, entre outros. Nos domicílios os níveis de contaminação se elevam pela precariedade das instalações hidráulicosanitárias, pela falta de manutenção dos reservatórios e pelo manuseio inadequado da água (BRASIL, 2003).

\subsection{Doenças de veiculação hídrica}

Grande parte das doenças existentes nos países em desenvolvimento, onde os sistemas de saneamento são precários, variam em intensidade, podendo ocorrer gastrenterites e enfermidades graves, algumas fatais e outras de proporções epidêmicas (BRASIL, 2003).

As doenças de veiculação hídrica são causadas, principalmente, por microorganismos patogênicos de origem entérica, animal ou humana, transmitidos basicamente pela rota fecal-oral, ou seja, excretados nas fezes de indivíduos infectados, e ingeridos através da água e/ou alimentos contaminados, o que torna primordial a avaliação microbiológica dos mesmos (GRABOW, 2003).

Os principais agentes biológicos encontrados nas águas contaminadas são as bactérias patogênicas, os vírus e os parasitas, os quais podem causar gastroenterites, caracterizadas por infecções com sintomas que incluem inapetência, náuseas, vômitos, diarréias (moderada a intensa), cólicas e desconforto abdominal (PECORA, 2008).

As bactérias patogênicas encontradas na água e/ou alimentos, constituem uma das principais fontes de morbidade em nosso meio. A contaminação da água do sistema público de abastecimento é geralmente detectada pela presença de bactérias pertencente à família 
Enterobacteriaceae, representada pela maior e mais heterogênea coleção de bactérias de importância clínica; o grupo Coliformes pertence a esta família.

O grupo dos Coliformes totais é constituído por bacilos gram-negativos, aeróbios ou anaeróbios facultativos, não formadores de esporos, oxidasenegativos, capazes de desenvolver na presença de sais biliares ou agentes tensoativos que fermentam a lactose com produção de ácido, gás e aldeído a 35,0 \pm 0,5ํํ em 24-48 horas, e que podem apresentar atividade da enzima Bgalactosidase. A maioria das bactérias do grupo coliforme pertence aos gêneros Escherichia, Citrobacter, Klebsiella e Enterobacter, embora vários outros gêneros e espécies pertençam ao grupo.

Os Coliformes termotolerantes formam um subgrupo das bactérias do grupo coliforme que fermentam a lactose a $44,5 \pm 0,2^{\circ} \mathrm{C}$ em 24 horas; tendo como principal representante a Escherichia coli, de origem exclusivamente fecal, que fermenta a lactose e manitol, com produção de ácido e gás a 44,5 \pm $0,2^{\circ} \mathrm{C}$, em 24 horas produz indol a partir do triptofano, oxidase negativa, não hidroliza a uréia e apresenta atividade das enzimas B-galactosidase e Bglucoronidase, sendo considerado o mais específico indicador de contaminação fecal recente e de eventual presença de organismos patogênicos (BRASIL, 2004).

Os vírus mais comumente encontrados nas águas contaminadas por dejetos humanos são, entre outros, os da poliomielite e da hepatite infecciosa tipos A e E.

Os poliovírus, pertencentes ao gênero Enterovírus, causam a poliomielite, uma doença aguda, que pode ocorrer sob a forma de infecção inaparente ou apresentar manifestações clínicas, frequentemente caracterizadas por febre, mal estar, cefaléia, distúrbios gastrointestinais e rigidez de nuca, acompanhadas ou não de paralisia. A transmissão ocorre no contato direto de pessoa para pessoa, ou de forma indireta, no contato com objetos, alimentos e água contaminada.

A intensa batalha pela erradicação da poliomielite conduziu à valiosa obtenção, produção e aplicação de vacinas, que reduziram acentuadamente a 
incidência da doença em todo o mundo. Tal ação acarretou no confinamento do poliovírus selvagem no sudeste asiático e em alguns países africanos. No entanto, ações de vigilância ambiental em águas residuárias fornecem uma valiosa informação sobre a quantidade de poliovírus excretados nas fezes de pessoas imunizadas; a água pode atuar como veículo de infecção a partir de cepas utilizadas nas vacinas (GONZÁLEZ et al., 2006).

A hepatite é uma doença infecciosa aguda, altamente contagiosa, transmitida por via fecal-oral, ocorrendo contaminação direta de pessoa para pessoa ou a partir do contato com alimento e água contaminados. Esta via de transmissão favorece a disseminação da infecção nos países em desenvolvimento, onde a contaminação dos reservatórios de água mantém a cadeia de transmissão da doença. Os sintomas da hepatite são febre baixa, fadiga, mal estar, inapetência, sensação de desconforto abdominal, náuseas, vômito, diarréia e no caso da hepatite A pode ocorre icterícia, persistindo de 2 a 4 semanas. As medidas de prevenção incluem hábitos de higiene e melhorias das condições sanitárias (BRASIL, 2005).

As enteroparasitoses podem afetar o equilíbrio nutricional, pois interferem na absorção de nutrientes, induzem sangramento intestinal, reduzem a ingestão alimentar e ainda podem causar complicações significativas como obstrução intestinal e formação de abcessos (SANTOS, 2007).

Dentre os parasitas, encontrados na água contaminada, destacam-se a Entamoeba histolytica, Ancylostoma sp., Hymenolepis sp., Ascaris sp., Giardia intestinalis, Cryptosporidium hominis.

Os protozoários e helmintos são causas comuns de infecção e doença em seres humanos e animais, são de importância sanitária, pois persistem na água e apresentam resistência ao cloro utilizado para descontaminação.

O controle dessas doenças é dificultado pelo fato dos organismos apresentarem, em seu ciclo vital, cistos, oocistos e ovos que são extremamente resistentes aos processos utilizados no tratamento da água, conforme pode ser observado no Quadro a seguir (CETESB, 2009). 
Quadro 1. Agentes patogênicos de veiculação hídrica e a significância sanitária em água de consumo humano.

\begin{tabular}{|l|ccc|}
\hline Microrganismo & $\begin{array}{c}\text { Significância } \\
\text { sanitária }\end{array}$ & $\begin{array}{c}\text { Persistência na } \\
\text { água }\end{array}$ & $\begin{array}{c}\text { Resistência ao } \\
\text { cloro }\end{array}$ \\
\hline Escherichia coli patogênica & alta & média & Baixa \\
Vírus da hepatite A & Alta & alta & Média \\
Vírus da hepatite E & Alta & alta & Média \\
Entamoeba hystolitica & Alta & média & Alta \\
Giardia intestinalis & Alta & média & Alta \\
Cryptosporidium hominis & Alta & alta & Alta \\
\hline
\end{tabular}

Fonte: Adaptado de WHO (2008).

Além do controle biológico (parasitas, bactérias e vírus) de qualidade da água, deve-se considerar também, a análise de parâmetros físico-químicos de grande relevância para a saúde pública. Dentre os recomendados, encontramse os valores de cloro e pH e a concentração de metais, os quais devem estar em conformidade com os valores estabelecidos pela legislação vigente.

Todas as formas de vida podem ser afetadas direta ou indiretamente pela presença de metais, quando em concentrações superiores às recomendadas. Muitos metais são essenciais para o crescimento de todos os tipos de organismos, desde as bactérias até mesmo o ser humano, mas eles são requeridos em baixas concentrações porque, quando em altas concentrações, podem danificar os sistemas biológicos por apresentarem características biocumulativas no organismo; metais na água são absorvidos pelo organismo humano através do trato gastrintestinal. Esta absorção pode ser afetada pelo $\mathrm{pH}$, pelas taxas de movimentação no trato digestivo e pela presença de outros materiais; combinações particulares desses fatores podem contribuir para a absorção de metais ser muito alta ou muito baixa no ser humano (FREITAS; BRILHANTE; ALMEIDA, 2001).

O excesso ou a deficiência de alguns metais essenciais podem causar danos à saúde humana, como alguns tipos de câncer, alterações no sistema 
reprodutivo, doenças cardiovasculares e neurológicas. O ser humano pode estar exposto a altos níveis de metais a partir de várias fontes, incluindo os alimentos e a água destinada ao consumo como as principais vias de contaminação (ROYCHOWDHURY; TOKUNAGA; ANDO, 2003; SILVA et al., 2005; ZHENG et al., 2007).Destacamos os seguintes metais:

\section{Mercúrio}

O mercúrio e o chumbo são metais tóxicos que afetam principalmente 0 sistema nervoso central (SNC). A exposição de crianças e recém-nascidos a esses metais pode colocar em riscos o desenvolvimento infantil e aumentar a vulnerabilidade desses indivíduos. É possível que a exposição aos metais tóxicos promova uma degeneração mais acelerada das funções do SNC (DÓREA; DONANGELO, 2006). O mercúrio é o único elemento dentre os metais tóxicos que se apresenta em diferentes formas químicas e físicas à temperatura ambiente. Todas as formas de mercúrio apresentam efeitos tóxicos em vários órgãos, especialmente nos rins. A exposição de indivíduos ao mercúrio pode alterar funções do sistema imunológico. A exposição aguda ao mercúrio causa lesões no pulmão e a crônica é caracterizada por sintomas neurológicos e psicológicos como tremor, mudanças de personalidade, cansaço, ansiedade, distúrbios do sono e depressão (JÄRUP, 2003).

\section{Chumbo}

Os sintomas da intoxicação aguda por chumbo incluem: dores de cabeça, irritabilidade, dores abdominais e outros relacionados ao sistema nervoso central. A encefalopatia é caracterizada pela perda do sono e cansaço. As crianças podem ser afetadas por distúrbios de comportamento, dificuldades de aprendizagem e coordenação. Em alguns casos, as pessoas podem sofrer de psicoses agudas, confusão mental e redução da consciência, deterioração da memória, redução da habilidade de compreensão das coisas. Alguns indivíduos ainda apresentam uma redução da velocidade de transmissão nervosa e também redução da sensibilidade dérmica (JÄRUP, 2003). 


\section{Cobre}

Cobre é um elemento essencial ao organismo, necessário para a ativação de mais de 30 proteínas, incluindo a superóxido dismutase, ceruloplasmina, lisiloxidase, citocromo-c-oxidase, tirosinase e dopamina-ßhidroxilase. A exposição primária ao cobre ocorre pela ingestão oral. O cobre induz necrose e apoptose em hepatócitos e parece que essa apoptose é através da ativação da esfingomielinase ácida e liberação de ceramida. $O$ transporte e a disponibilidade do cobre nos sistemas parecem ser regulados por vários metais, como o zinco, cádmio e molibdênio (RANA, 2008).

\section{Cádmio}

Metal considerado um dos principais contaminantes ambientais. A população geralmente é exposta principalmente através da ingestão de água e alimentos (WHO, 2000; ATSDR, 2008). O Cd é um poluente industrial proveniente da fabricação de fertilizantes, cimento, aço, queima de combustíveis fósseis e sedimentos de esgotos. Pode causar danos renais e hepáticos, hipertensão arterial, destruição do tecido testicular, deformidades nos eritrócitos e alterações pulmonares. Os trabalhadores de fábricas de pigmentos, baterias, produção de metais e de incineração de lixo são expostos de forma ocupacional (ATSDR, 2008). A exposição ao cádmio induz a lesões renais, causando uma disfunção tubular, que promove um aumento da proteinúria. Esse dano pode progredir para lesões mais severas, levando a uma falha renal crônica. Há evidências sugestivas de que o cádmio cause lesões cardiovasculares severas; baixas exposições de cádmio causariam danos esqueléticos, como osteoporose, e aumento no número de fraturas ósseas. Além disso, a IARC (International Agency for Research on Câncer) classificou o cádmio como carcinógeno humano, pelas possíveis associações com cânceres de pulmão, próstata e renal (JÄRUP, 2003). 


\section{Cromo}

Metal de transição com ações diversas no organismo, dependendo do seu estado de oxidação. Quando está no estado mais oxidado, como cromo IV $(\mathrm{Cr}+6)$ é considerado como carcinogênico e é capaz de induzir citotoxicidade e genotoxicidade, com a capacidade de formação de intermediários fortemente reativos, capazes de gerar muitos danos celulares. Já o cromo III $(\mathrm{Cr}+3)$ é considerado um micronutriente essencial para os humanos, envolvido no metabolismo da glicose, embora pareça não haver manifestações clínicas quando sua concentração é deficiente (LEVINA; LEY, 2008). A exposição ocupacional ao cromo VI parece ser uma causa de câncer de pulmão e também está associado ao risco de câncer nasal. É sugerido também que há evidências que águas contaminadas com cromo VI possa causar carcinogenicidade na cavidade oral e no intestino delgado (SALNIKOW; ZHITKOVICH, 2008).

\section{Manganês}

A presença do manganês no metabolismo é essencial e a sua deficiência acarreta sintomas como lesões de pele e más formações da medula. Em ratos, essa deficiência mostra um aumento nos níveis séricos de cálcio e fósforo e uma diminuição do cálcio na medula, sugerindo então uma alteração no metabolismo na medula. Além disso, em humanos, níveis sangüíneos com baixas concentrações de manganês têm sido associados a algumas doenças, como osteoporoses, doença de Perthe e casos de epilepsia, tanto em adultos quando em crianças. Suspeita-se que nos casos de epilepsia, os níveis baixos de manganês no cérebro sejam decorrentes das baixas concentrações do metal no sangue. Apesar de sinais e sintomas da deficiência de manganês, o que mais ocorre na realidade é a super exposição, que induz uma lesão neurodegenerativa permanente, progressiva, resultando em características similares à doença de Parkinson (CROSSGROVE; ZHENG, 2004). 


\section{Zinco}

A deficiência de zinco pode produzir retardamento no crescimento, perda de cabelo, diarréias, impotência e imaturidade sexual nos adolescentes, apatia, cansaço e depressão, lesões oculares e de pele, inclusive acne, unhas quebradiças, amnésia, perda de apetite, perda de peso e problemas de crescimento, aumento do tempo de cicatrização de ferimentos e anomalias no sentido do olfato. As causas que podem provocar uma deficiência de zinco são a insuficiente quantidade na dieta alimentar e a dificuldade na absorção do mineral que pode ocorrer em casos de alcoolismo, quando é eliminado pela urina ou, ainda, devido à excessiva eliminação por causa de desordens digestiva. O excesso de zinco tem sido associado com baixos níveis de cobre, alterações na função do ferro, diminuição da função imunológica e dos níveis de colesterol bom (MARET; SANDSTEAD, 2006).

Não só os metais, mas outros parâmetros físicos, químicos e microbiológicos precisam ser avaliados e monitorados de forma mais ampla do que a simples verificação dos padrões estabelecidos legalmente para a qualidade da água. Esse controle envolve também a necessidade de compreensão das alterações ocorridas e de suas possíveis causas, objetivando a tomada de decisões e elaboração de ações voltadas à redução de danos ao meio ambiente e à saúde humana (CASTANIA, 2009).

Diante do contexto apresentado, consideramos que a vigilância em saúde ambiental relacionada à qualidade da água para consumo humano é uma atividade investigativa, preventiva e corretiva, com o objetivo de assegurar a confiabilidade e segurança da água para consumo humano (BRASIL, 2003).

"O consumo de água segura é de importância fundamental para a sadia qualidade de vida e de proteção contra as doenças, sobretudo aquelas evitáveis, relacionadas a fatores ambientais e que têm afligido populações em todo o mundo" (BRASIL, 2003).

Portanto, esta investigação, fundamentada na avaliação das condições microbiológicas e físico-químicas da água armazenada, poderá contribuir para ações individuais e coletivas no que diz respeito à manutenção da qualidade da 
água a ser consumida, proveniente dos reservatórios, nos domicílios e Unidades Básicas de Saúde do município de Ribeirão Preto - SP. 
3. OBJETIVOS 


\subsection{Objetivo geral}

- Analisar as condições microbiológicas e físico-químicas da água de reservatório domiciliar e predial e sua significância sanitária.

\subsection{Objetivos específicos}

- Verificar as condições de limpeza e manutenção de reservatórios domiciliares de água no município de Ribeirão Preto-SP.

- Caracterizar e quantificar os parasitas e bactérias mais frequentes nas amostras de água coletadas nos reservatórios domiciliares e nos reservatórios das Unidades Básicas de Saúde do município de Ribeirão Preto - SP.

- Quantificar a concentração de metais em água proveniente de reservatórios de água, domiciliares e de Unidades Básicas de Saúde, no município de Ribeirão Preto-SP. 
4. MATERIAL E MÉTODOS 


\subsection{Delineamento da pesquisa}

Trata-se de uma pesquisa de caráter descritivo-exploratório, de corte transversal, com características observacionais e de abordagem quantitativa, para uma melhor compreensão da realidade estudada (PEREIRA, 2005).

\subsection{Local de Estudo}

O município de Ribeirão Preto está localizado na região Nordeste do Estado de São Paulo (Figura 14), em uma área de $650 \mathrm{~km}^{2}$. Segundo dados do Censo 2010, o município possui uma população de cerca de 605.114 habitantes, residentes em mais de 140.000 domicílios (IBGE, 2010).

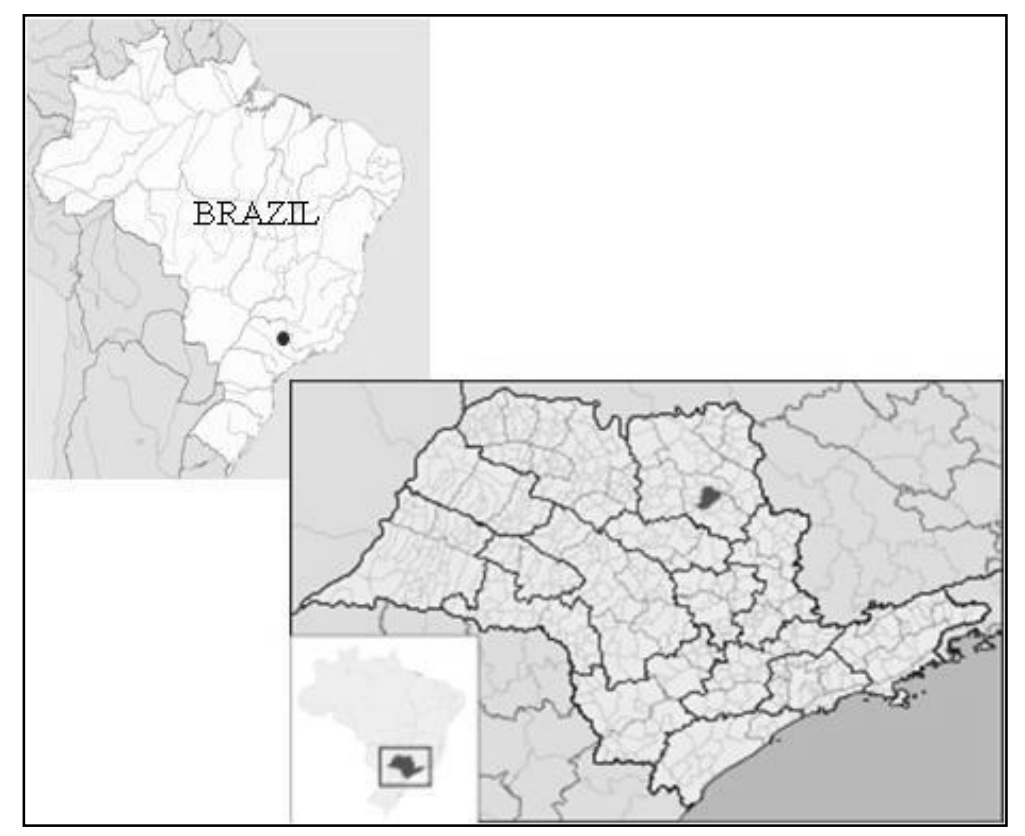

Figura 14 - Localização do município de Ribeirão Preto no Estado de São Paulo.Adaptado de: Wikipédia (2010). 
A cidade possui 277 estabelecimentos de saúde no total, sendo 590 número de estabelecimentos da rede pública de saúde e 218 da rede privada. Segundo dados disponibilizados pela Secretaria de Saúde do município, a atenção básica à saúde é oferecida em diversos locais, dentre eles atualmente são encontradas Unidades Básicas de Saúde (UBS), Unidades Básicas Distritais de Saúde (UBDS), Centros de Saúde Escola (CSE) e Núcleos de Saúde da Família (NSF).

Os serviços de saúde e as residências do município recebem água da rede de distribuição, fornecida pelo Departamento de Água e Esgotos de Ribeirão (DAERP), responsável pela captação da água subterrânea (proveniente do Aqüífero Guarani), através de 104 poços artesianos. O DAERP, criado em 1969, é uma autarquia que administra os serviços de abastecimento de água, esgoto e limpeza do município, e atende a toda a população do município (RIBEIRÃO PRETO, 2009).

A investigação foi realizada a partir de coleta de amostras de água de reservatórios domiciliares (caixas d'água), diretamente das torneiras, em 217 domicílios e em 23 UBSs do município de Ribeirão Preto - SP. O número de domicílios foi definido seguindo a normatização sobre o tamanho representativo de amostras de água em relação à densidade populacional da Portaria 518/2004 do Ministério da Saúde, que aponta para cidades com 205.000 habitantes ou mais, os seguintes números amostrais: Número de coletas para coliformes totais $=105+1$ para cada 5.000 habitantes a mais, não ultrapassando o máximo de 1.000 amostras.

Considerando que o município de Ribeirão Preto, no momento da coleta possuía uma população aproximada de 560.000 habitantes, tivemos: 105 (referente a 250.000 habitantes) + 1 para cada 5.000 (referente aos 560.000 habitantes do município) obtém-se 105+112=217 amostras a serem coletadas nos domicílios, os quais foram escolhidos aleatoriamente. A seleção dos domicílios foi pautada na metodologia empregada pelo Instituto Brasileiro de Geografia e Estatística (IBGE) para a realização da PNAD. 
Após a seleção das UBSs, localizadas em diferentes distritos de saúde do município (Figura 15), foi realizada uma visita, em cada local, com a finalidade de entregar uma cópia da autorização da Secretaria da Saúde do município de Ribeirão Preto-SP, para a posterior realização das coletas de amostras de água, bem como explicar os objetivos da pesquisa, deixando uma cópia do resumo do projeto para o gerente da unidade.

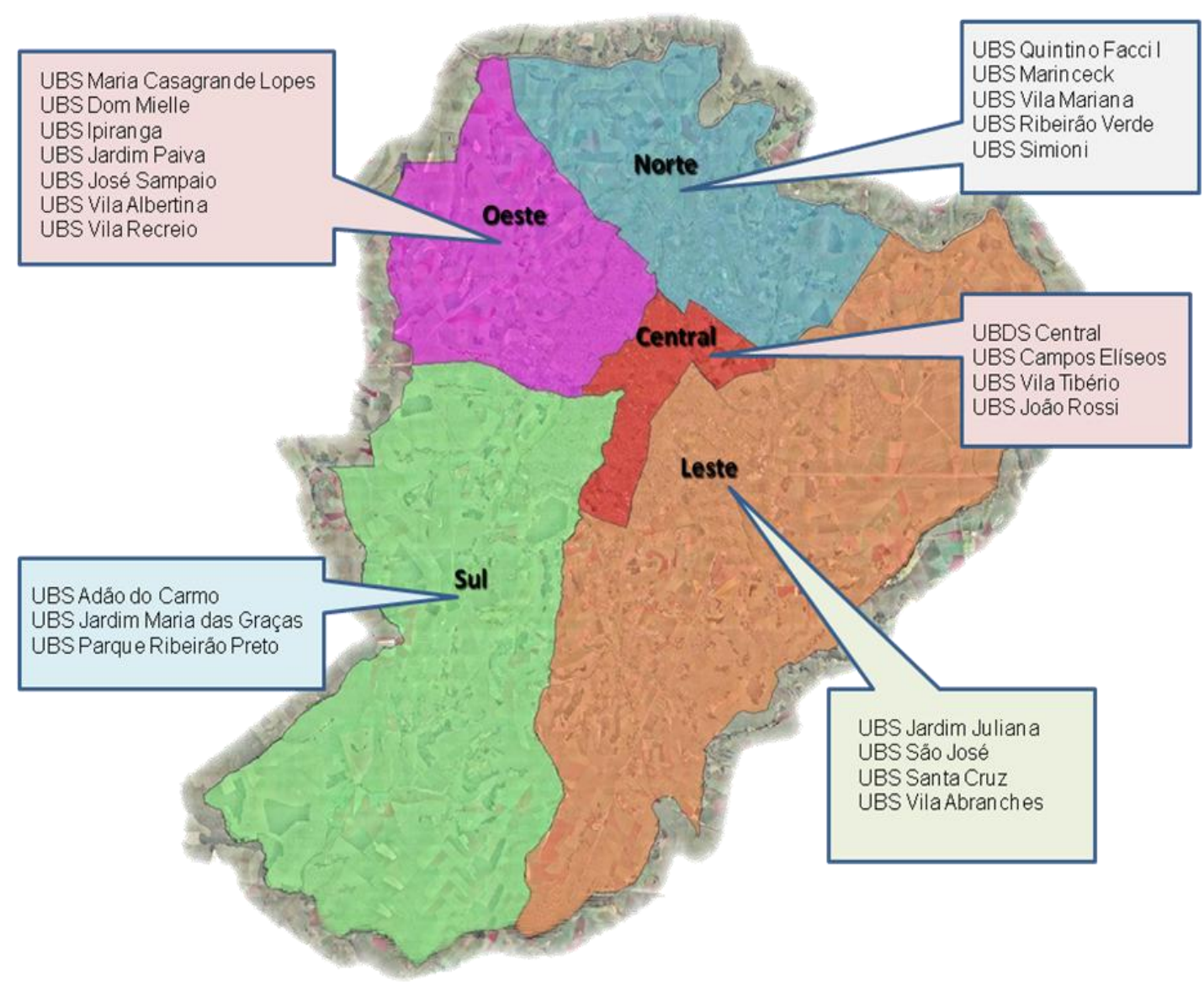

Figura 15 - UBSs do município de Ribeirão Preto-SP, onde foram coletadas amostras de água. Adaptado de: Departamento de Vigilância em Saúde e Planejamento, 2008. 


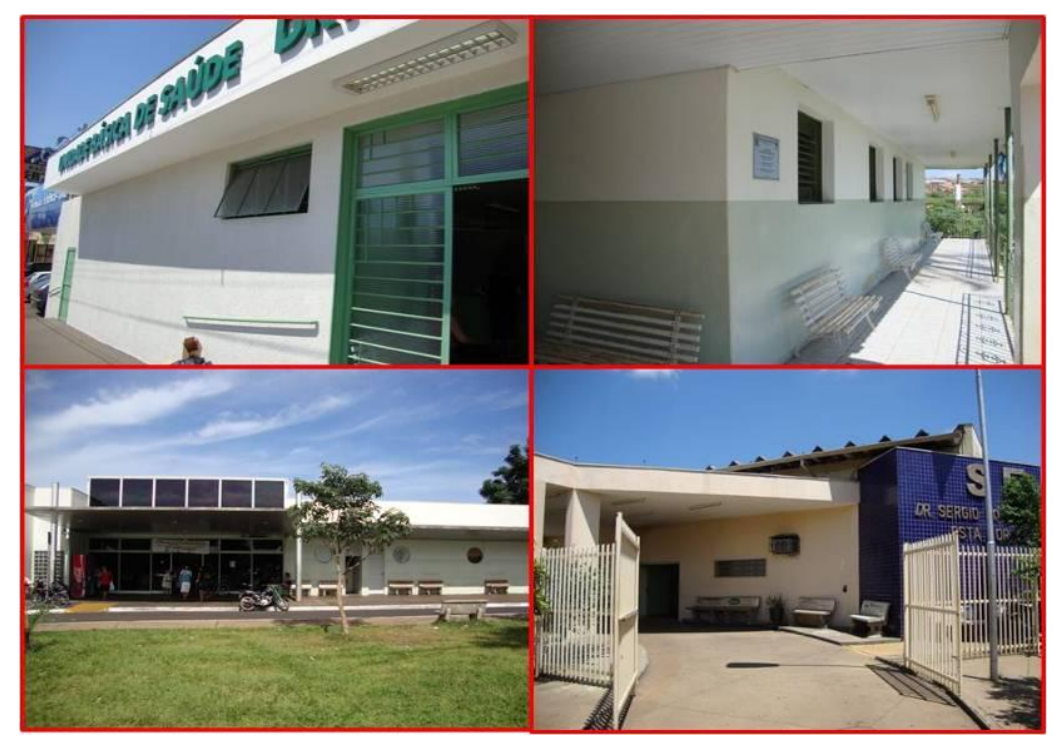

Figura 16- Vista parcial de quatro UBS localizadas no município de Ribeirão Preto-SP, onde foram coletadas amostras de água. Fonte: Julião, F.C. (2010).

Para a seleção dos domicílios foram adquiridos os mapas dos setores censitários do município de Ribeirão Preto-SP, totalizando 642 setores e posteriormente os domicílios foram sorteados utilizando-se o programa Microsoft Office Excell $2007^{\circledR}$. Foram sorteados 217 setores censitários e em cada um deles, um único domicílio foi escolhido como local de coleta de amostras de água, obtendo-se assim, 217 domicílios para compor a amostra desta pesquisa. Nas Figuras 17 e 18 são apresentados, respectivamente, um setor censitário, destacado no centro do mapa e a representação do protocolo adotado para seleção do domicílio em cada setor censitário. 


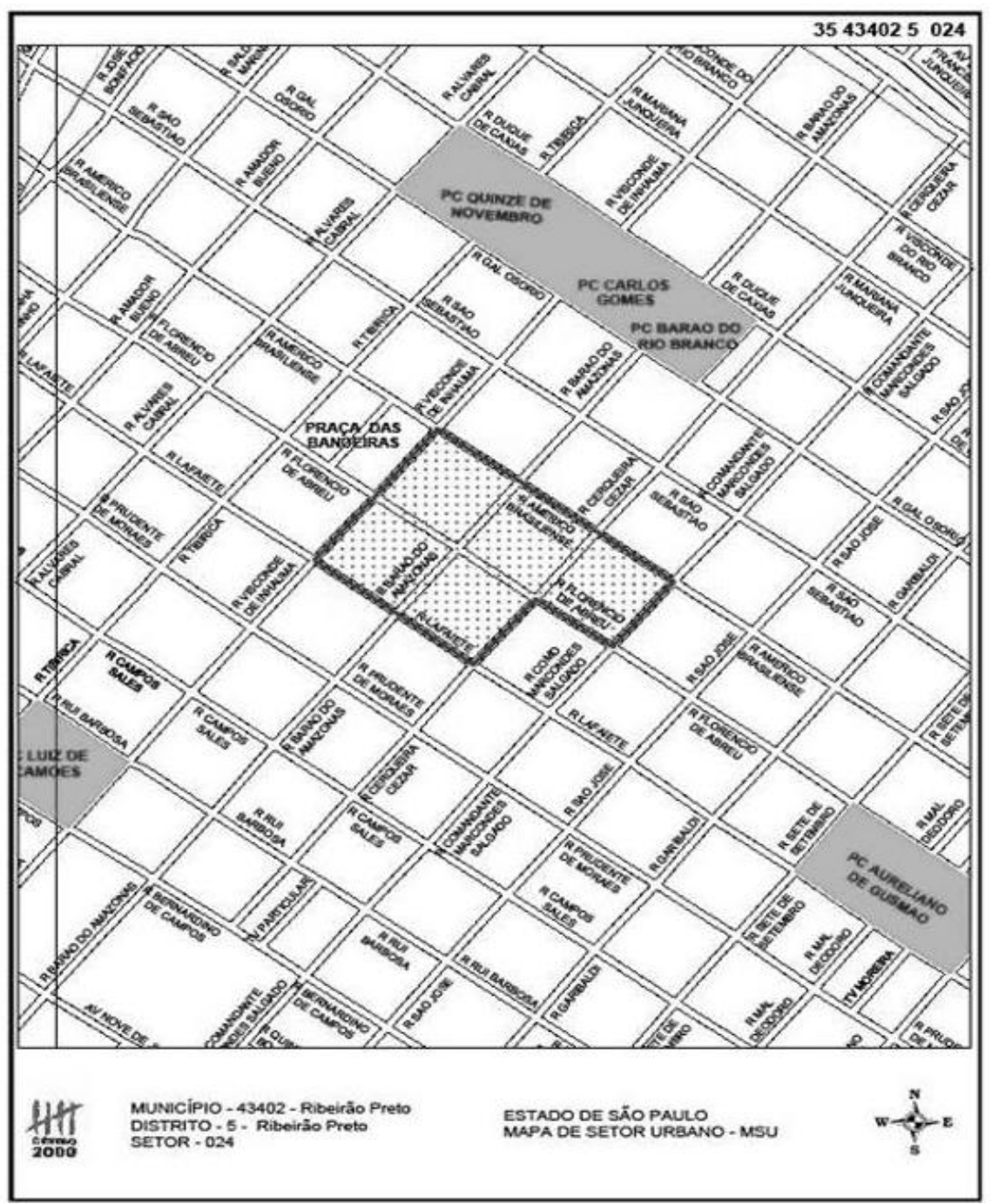

Figura 17 - Representação gráfica de um setor censitário do município de Ribeirão Preto - SP, destacado no centro do mapa. Fonte: IBGE. 


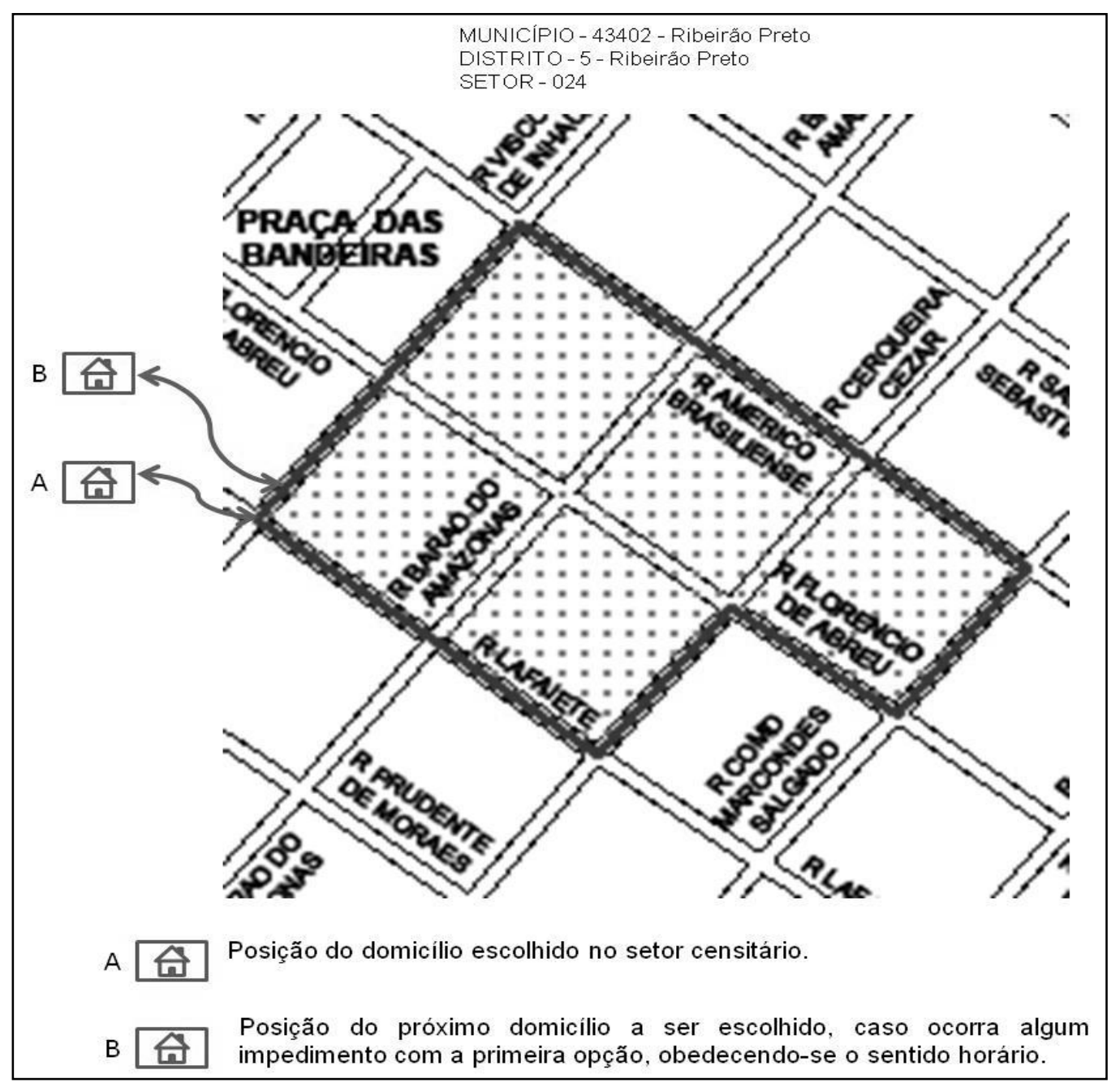

Figura 18 - Representação gráfica da posição do domicílio sorteado no setor censitário. Fonte: Adaptado de IBGE.

Os moradores dos domicílios e os gerentes das UBSs receberam esclarecimentos sobre os procedimentos adotados para a coleta de amostras de água e a posterior análise laboratorial. Num primeiro momento foram informados sobre as questões éticas da pesquisa, com a apresentação de uma carta com a descrição dos objetivos e metodologia do projeto, bem como o parecer da Comissão de Ética em Pesquisa da Escola de Enfermagem de Ribeirão Preto (Anexo A). Após os esclarecimentos, os participantes, na presença da pesquisadora, realizaram a leitura do Termo de Consentimento Livre e Esclarecido (Apêndice A), o qual foi assinado no momento da coleta. 
Nas UBSs, os gerentes receberam uma cópia da autorização da Secretaria Municipal da Saúde (Anexo B), autorizando a realização do estudo.

\subsection{Coleta de informações sobre a limpeza e manutenção dos reservatórios domiciliares de água}

Previamente ao início das coletas de amostras de água nos 217 domicílios sorteados aleatoriamente para o estudo, foram feitas observações sobre a limpeza e manutenção dos reservatórios domésticos de água em 78 domicílios localizados no município de Ribeirão Preto-SP.

Cada participante respondeu de próprio punho a um questionário contendo 10 questões de múltipla escolha (Apêndice B).

O levantamento norteou os procedimentos metodológicos relacionados ao ponto de coleta das amostras dentro do domicílio e as observações dos parâmetros físicos-químicos da água, de limpeza e localização do reservatório, bem como o material utilizado em sua fabricação.

\subsection{Coleta das amostras}

Em cada ponto selecionado (domicílios e UBSs) foram coletadas:

- 1 amostra de $200 \mathrm{ml}$ de água para análise bacteriológica, coletada em frascos de borosilicato previamente esterilizados. A coleta das amostras para análise bacteriológica foi realizada de acordo com os procedimentos do "Standard Methods for the Examination of Water and Wastewater" da American Public Health Association (APHA, 2005) e do "Guia de Coleta e Preservação de Amostras de Água" da Companhia de Tecnologia de Saneamento Ambiental (CETESB, 1998).

- 1 amostra de 1L de água para análise parasitológica, coletada em um frasco plástico; será seguido o "Guia de Coleta e Preservação de Amostras de Água" (CETESB, 1998), que recomenda a coleta de no mínimo $1 \mathrm{~L}$ de água para cada amostra. As amostras foram 
transportadas ao laboratório, em caixa térmica contendo gelo (temperatura de $4^{\circ} \mathrm{C}$ ), e analisadas em um período inferior a 24 horas.

- 2 amostras de $50 \mathrm{ml}$ de água para dosagem de metais, coletada em tubo de polietileno provido de tampa, previamente submergido em solução de ácido nítrico a $30 \%$ por 24 horas e posteriormente enxaguados em água Milli-Q.

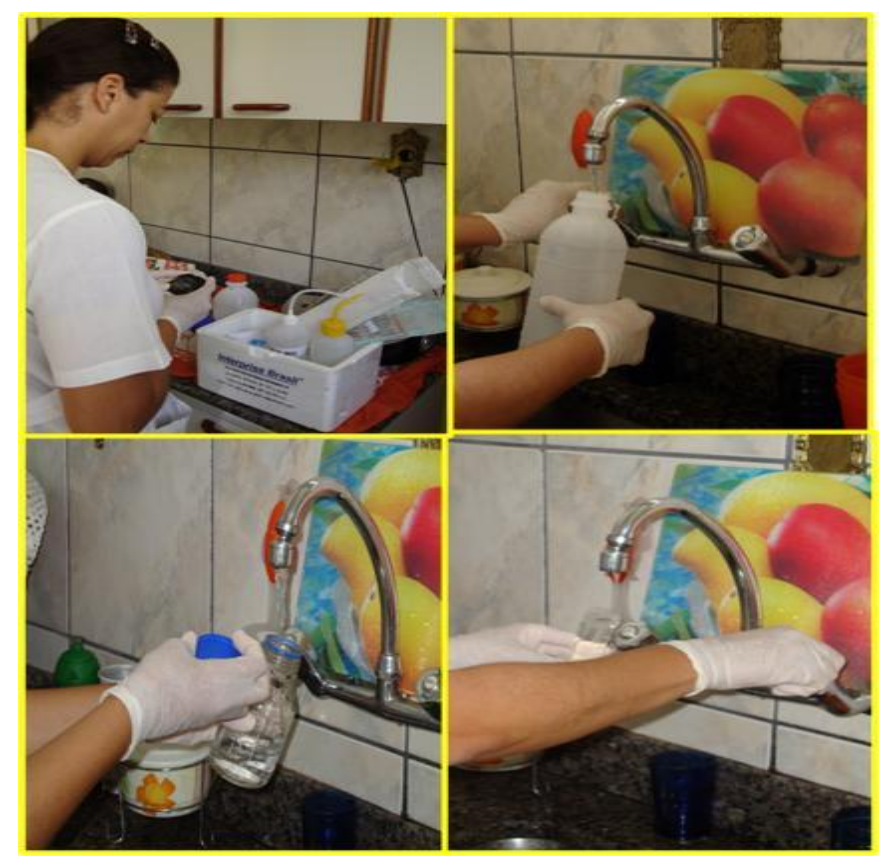

Figura 19 - Coleta de amostras de água para análise parasitológica, bacteriológica e metais tóxicos, realizada em domicílio localizado no município de Ribeirão Preto. Fonte: Julião, F.C. (2010).

Cada amostra de água coletada foi transportada ao Laboratório de Ecotoxicologia e Parasitologia Ambiental da Escola de Enfermagem de Ribeirão Preto (LEPA/EERP/USP). Neste local, foram realizadas as análises bacteriológicas e parasitológicas. Para a análise de metais, as amostras foram congeladas e posteriormente enviadas ao Laboratorio de Toxicologia y Salud Ambiental da Facultad de Medicina y Ciencias de la Salud da "Universidad Rovira i Virgili”, na cidade de Reus, Espanha. 


\subsection{Preparação e análise das amostras}

\section{$\checkmark$ Análise bacteriológica}

Para a análise bacteriológica determinou-se o Número Mais Provável (NMP) de indicadores de contaminação em uma dada amostra efetuada a partir de aplicação da técnica de tubos múltiplos, a qual consiste na inoculação de volumes decrescentes da amostra, em meio de cultura adequado ao crescimento dos microrganismos pesquisados, sendo cada volume inoculado em uma série de tubos.

Para análises de amostras de águas, tem sido utilizado preferencialmente o fator 10 de diluição, sendo inoculados múltiplos e submúltiplos de $1 \mathrm{ml}$ da amostra, usando-se séries de 3 ou 5 tubos para cada volume a ser inoculado (CETESB, 2009).

No momento da análise, a amostra foi mantida tampada e agitada aproximadamente 25 vezes. Com uma pipeta esterilizada foram transferidos 10 $\mathrm{ml}$ da amostra para um frasco contendo $90 \pm 2 \mathrm{ml}$ de água destilada estéril (Figura 20). Desta forma preparou-se a primeira diluição decimal $\left(10^{-1}\right)$, sendo que $1 \mathrm{ml}$ da mesma correspondeu a $0,1 \mathrm{ml}$ da amostra; procedendo nesta sequência até obter as diluições desejadas $\left(10^{-1}, 10^{-2}, 10^{-3}\right)$. 


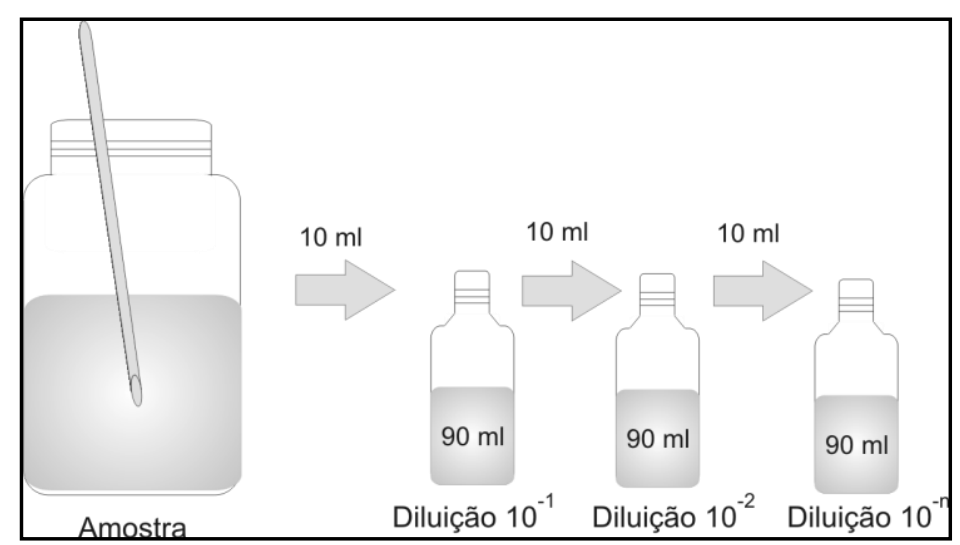

Figura 20 - Esquema ilustrativo do preparo das diluições decimais da amostra de água. Fonte: Castania, J. (2009).

Com uma pipeta de $5 \mathrm{ml}$ foi inoculado $1 \mathrm{ml}$ da amostra em cada um dos tubos correspondentes a essa quantidade de inóculo. Após a inoculação de todos os volumes da amostra e/ou das diluições requeridas para o exame, a estante contendo os tubos inoculados foi armazenada em estufa de cultura a $35 \pm 0,5^{\circ} \mathrm{C}$, durante $24 \pm 2$ horas. Todo procedimento foi realizado a partir da Técnica de Tubos Múltiplos, a qual está baseada na estimativa de coliformes em uma amostra, calculada a partir da combinação de resultados positivos e negativos.

Leitura para coliformes totais: após 24 horas de incubação, efetuou-se a leitura, considerando como resultado positivo para coliformes totais 0 aparecimento de uma coloração amarela nos tubos ou frascos. A observação do resultado das análises consiste em uma estimativa de coliformes em uma amostra, calculada a partir da combinação de resultados positivos e negativos, obtidos mediante a aplicação da técnica denominada Tubos Múltiplos.

Leitura para Escherichia coli: após a leitura para coliformes totais, efetuou-se a exposição de cada tubo ou frasco positivo à luz ultravioleta (366nm, 6W) a uma distância de 6 a $8 \mathrm{~cm}$ em ambiente escuro. Se Escherichia. coli estivesse presente, uma fluorescência azul seria observada (Figura 21). Em caso de dúvida, a amostra seria incubada a $35 \pm 0,5^{\circ} \mathrm{C}$ por um período 
adicional de 4 horas. A intensificação da fluorescência indicaria um resultado positivo.

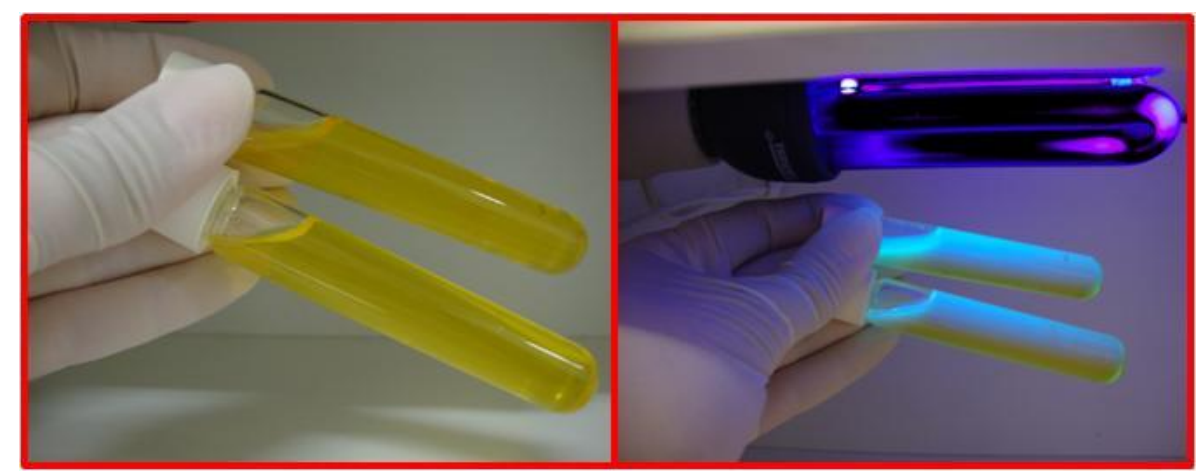

Figura 21 - Confirmação de teste positivo para coliformes totais, visualização de coloração amarelada; confirmação de teste positivo para Escherichia coli, visualização de fluorescência azul. Fonte: Julião, F.C. (2010).

As amostras foram preparadas com a utilização de um Kit denominado Colilert $^{\circledR}$, utilizado para a detecção e confirmação simultâneas de Coliformes totais e Escherichia coli em água. O princípio deste método é baseado na Tecnologia do Substrato Definido, no qual, o produto possui nutrientes indicadores que desenvolvem coloração e/ou fluorescência quando o meio de cultura é metabolizado pelas bactérias.

O cálculo e expressão dos resultados foram expressos como Número Mais Provável de microrganismos em cada $100 \mathrm{~mL}$ - NMP/100mL, para coliformes totais e Escherichia coli, baseados, respectivamente, no número de tubos com coloração amarela e nos quais é verificada o desenvolvimento de fluorescência azul, com posterior interpretação utilizando-se uma tabela que apresenta valores para combinações de positivos e negativos.

Os resultados para a Técnica de Tubos Múltiplos são expressos em NMP/100 mL. No entanto, para cada combinação de resultados positivos e negativos existem índices de NMP e limites de confiança de 95\% a serem considerados de acordo com o volume da amostra e a série de inoculação (CETESB, 2009), conforme demonstrado a seguir. 


\begin{tabular}{|ccc|}
\hline Número de tubos & Volumes da amostra & Resultado (NMP/100mL) \\
5 & $20 \mathrm{~mL}$ & $<1,1$ \\
10 & $10 \mathrm{~mL}$ & $<1,1$ \\
5 & $10 \mathrm{~mL}$ & $<1,8$ \\
5 & $1 \mathrm{~mL}$ & $<1,8$ \\
5 & $0,1 \mathrm{~mL}$ & $<1,8$ \\
\hline
\end{tabular}

Durante os procedimentos para a análise bacteriológica, foram realizados controles microbiológicos para o processo de esterilização, realizando-se testes com os equipamentos (autoclaves) e meio de cultura (Colilert ${ }^{\circledR}$ ).

Os materiais utilizados para a coleta e preparação das amostras para a análise bacteriológica foram esterilizados em autoclave horizontal (ODONTOBRÁS ${ }^{\circledR}$ MK300 12L) e vertical (FABBE-PRIMAR ${ }^{\circledR}$ 30L). O controle microbiológico das autoclaves utilizadas no LEPA-EERP foi realizado utilizando-se um bioindicador (Sterikon ${ }^{\circledR}$ Plus Bioindicator). O método empregado consiste em realizar um controle positivo e negativo, com ampolas contendo esporos bacterianos do microrganismo Geobacillus stearothermophilus.

Para o uso do controle foram seguidas as recomendações do fabricante. A coloração violeta indicou ausência de crescimento bacteriano após esterilização nas autoclaves e a coloração amarela (controle positivo) indicou a presença do microrganismo na ampola não esterilizada (Figura 22). Desta forma foi possível averiguar que o processo de esterilização ocorreu adequadamente. 


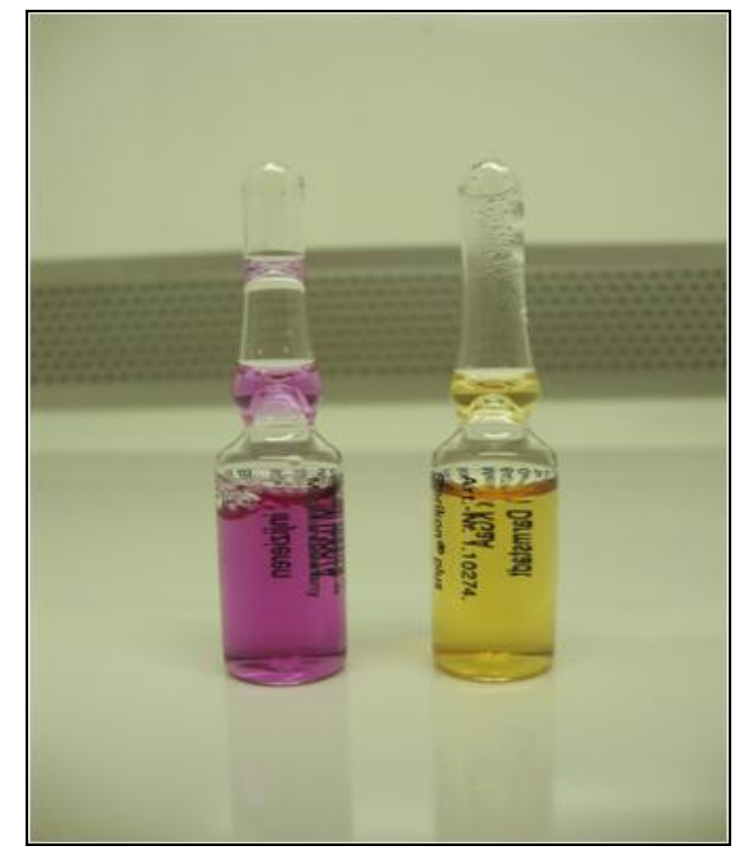

Figura 22 - Controle positivo e negativo após esterilização. Fonte: Julião, F.C. (2010)

Além do controle microbiológico dos equipamentos, foi efetuado também um controle positivo para a análise bacteriológica (Figura 23), objetivando assegurar a confiabilidade do meio de cultura utilizado no processo descrito na metodologia do projeto.
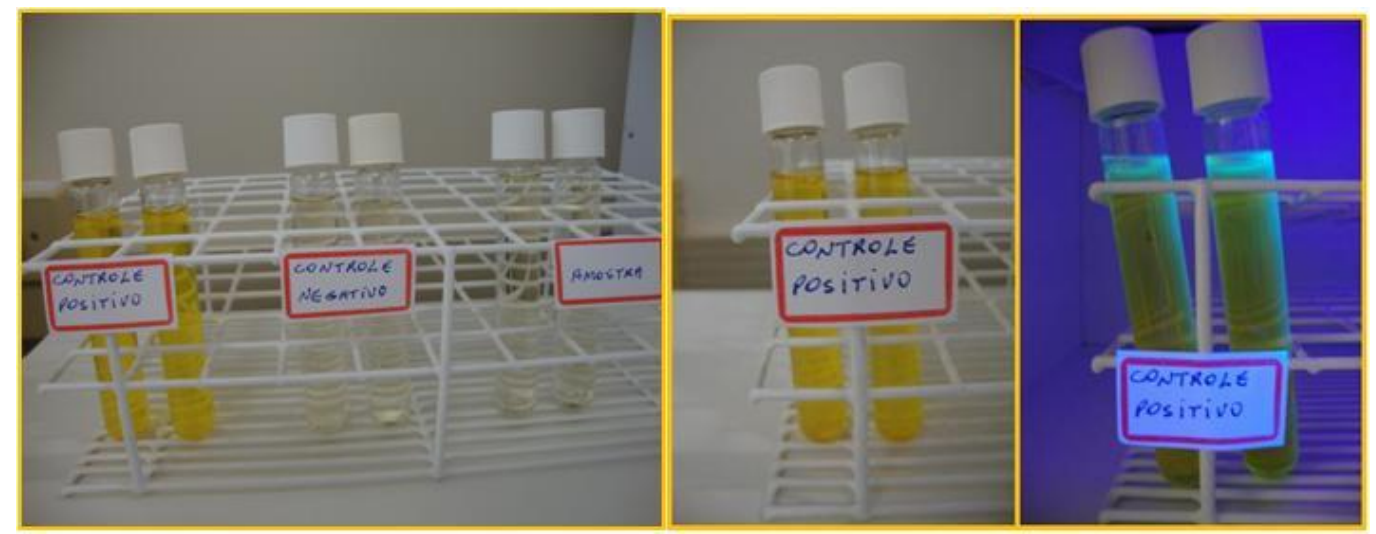

Figura 23 - Controle Positivo realizado juntamente com a análise das amostras de água. Verificação da Presença/Ausência de Coliformes totais e Escherichia coli. Fonte: Julião, F.C. (2010). 


\section{$\checkmark$ Análise Parasitológica}

Para a verificação da presença de ovos, cistos e larvas, foi realizado o método de sedimentação. Todas as amostras foram tratadas como contaminadas, portanto manipuladas com uso de luvas descartáveis, máscaras, aventais e óculos de proteção. Após a coleta, as amostras foram homogeneizadas lentamente e transferidas para um cálice de sedimentação de $500 \mathrm{ml}$ onde permaneceram em repouso durante um período de 2 a 24 horas. Posteriormente coletou-se $1 \mathrm{ml}$ do material sedimentado, com o auxílio de uma pipeta Pasteur e depositado sobre uma lâmina e corado com uma gota de solução lugol [lodeto de Potássio Cristalizado (KI) (4,)g); lodo em pó (I2) (2,0g); Água destilada q.s.p. $(100 \mathrm{ml})$ ]. Em seguida, o material foi analisado em microscópio óptico com aumento de 100 a 400 vezes (NIKON - modelo E200). Realizou-se a análise quantitativa com a utilização da câmara de SedgewickRafter (Figura 24). Foi colocado $1 \mathrm{ml}$ da amostra com o auxílio da pipeta Pasteur e após o preenchimento com a amostra, agitou-se, delicadamente, a câmara com movimentos desordenados para a maior distribuição homogênea do material. Em seguida, a câmara permaneceu em repouso durante alguns minutos para a sedimentação da amostra.

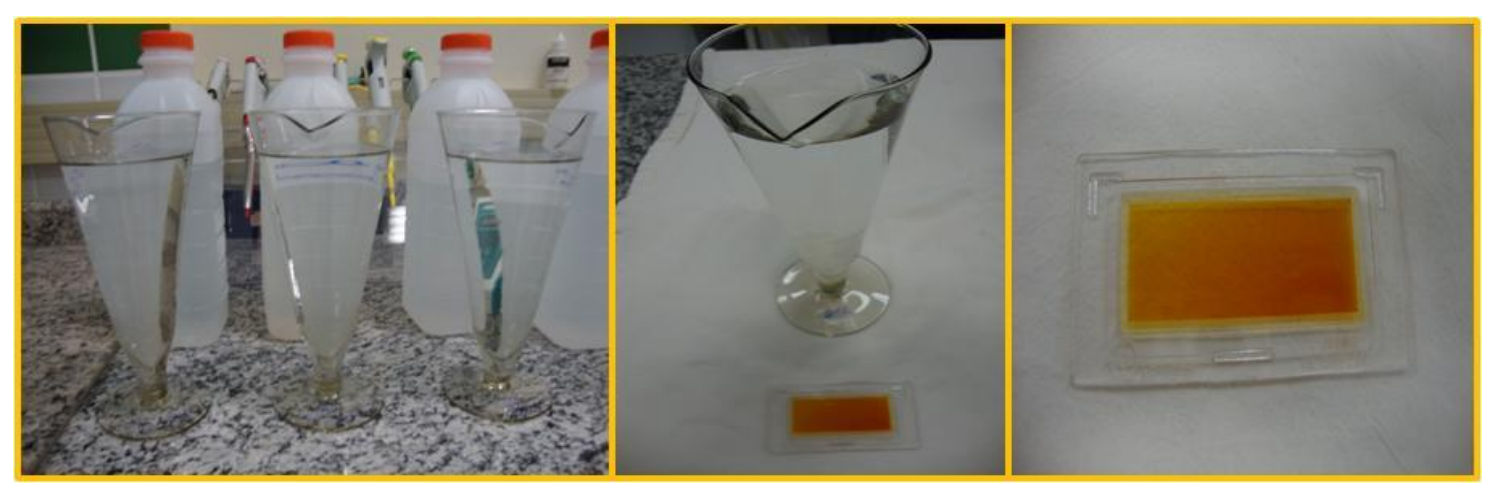

Figura 24 - Amostras de água em cálices de sedimentação e câmara de Sedgewick-Rafter preparada para a leitura de ovos, cistos e larvas de parasitas. Fonte: Julião, F.C. (2010). 
Após a leitura, percorrendo toda a área da câmara, realizou-se um cálculo para obter o resultado dos microorganismos por milímetro da amostra (APHA,2005).

$$
\text { № microorganismos } / \mathrm{ml}=\frac{\mathrm{C} \times 1000 \mathrm{~mm}^{3} / \mathrm{ml}}{\mathrm{A} \times \mathrm{D} \times \mathrm{F}}
$$

Onde: $\mathrm{C}=$ número de microorganismos contados;

$\mathrm{A}=$ área de um campo $\left(\mathrm{mm}^{2}\right)$;

$\mathrm{D}=$ profundidade de um Campo $-1 \mathrm{~mm}$;

$\mathrm{F}=$ número de campos contados

\section{$\checkmark$ Dosagem de metais}

As amostras para análise de metais foram fixadas com a adição de ácido nítrico (HNO3) de alta pureza e mantidas a uma temperatura de $-18^{\circ} \mathrm{C}$ até 0 momento de análise das amostras.

As dosagens foram determinadas por Espectroscopia com Plasma Induzido-Espectroscopia de Massas (ICP-MS, Perkin Elmer Elan 6000) no Laboratorio de Toxicologia y Salud Ambiental de la Universidad Rovira i Virgili. Os limites de detecção de cada metal estão descritos a seguir:

\begin{tabular}{|l|c|}
\hline \multicolumn{1}{|c|}{ Metais } & LD $(\boldsymbol{\mu g} / \mathbf{L})^{\star}$ \\
\hline As (Arsênio); Be (Berílio); Cu (Cobre); Hg (Mércúrio); Ni (Níquel) & 0,20 \\
Cr (Cromo); Zn (Zinco) & 0,50 \\
Cd (Cádmio); Pb (Chumbo); Mn (Manganês); TI (Tálio) & 0,05 \\
Sn (Estanho) & 0,10 \\
V (Vanádio) & 1,00 \\
\hline${ }^{*}$ LD - Limite de Detecção em $\mu \mathrm{g} / \mathrm{L}$. &
\end{tabular}

A curva de calibração foi definida a partir de uma solução estoque de cada metal, cuja concentração exata é de $1000 \mathrm{mg} / \mathrm{L}$, preparada uma solução padrão para cada metal em concentrações específicas. 
Para validação dos métodos utilizou-se padrões certificantes de água potável do Instituto Quality Control Technologies Pty Ltd., Queensland, Austrália.

\subsection{Leitura dos valores de Cloro e pH}

$\checkmark$ Cloro - utilizou-se um medidor modelo HI 93734 da Hanna Instruments ${ }^{\circledR}$ o qual possibilitou a medida de cloro residual livre presente na água. Foram adicionados $5 \mathrm{ml}$ do reagente HI 93734B-0 (Free \& Total Chlorine Reagent B) em uma cubeta de vidro, completando-se o volume total com água da amostra coletada. A cubeta foi introduzida no aparelho para zerar a leitura. Feito isso, adicionou-se o reagente em pó HI 93701-0 (Free Chlorine Reagent), agitando-se lentamente para que fosse dissolvido. A cubeta foi introduzida novamente no aparelho e a partir deste momento cronometrado 1 minuto para fazer a leitura do teor de cloro em $\mathrm{mg} / \mathrm{L}$ no visor do aparelho. Vale ressaltar que este procedimento foi realizado com a utilização de luvas descartáveis para evitar a interferência da impressão digital no vidro da cubeta.

$\checkmark \mathrm{pH}-\mathrm{A}$ análise do $\mathrm{pH}$ da água foi realizada pelo método potenciométrico, utilizando-se o pHmetro portátil, modelo $\mathrm{pH}-100 / \mathrm{pHTek}$ com eletrodo combinado de baixa força iônica, previamente calibrado com soluções tampão de $\mathrm{pH}$ 4,0 e 7,0, semanalmente. O eletrodo foi lavado com água destilada e introduzido na amostra de água coletada para leitura do valor de $\mathrm{pH}$ apresentado no visor digital do aparelho.

\subsection{Análise dos resultados}

Como guia de referência para a análise dos resultados utilizou-se a Portaria 518/2004 (BRASIL, 2004) - que estabelece os procedimentos e responsabilidades relativos ao controle e vigilância da qualidade da água para consumo humano e seu padrão de potabilidade, e dá outras providências. 
Foram utilizados também os parâmetros recomendados pelo Guidelines for Drinking Water Quality (WHO, 2008).

Para a análise estatística dos resultados finais, os valores resultantes de todas as análises foram compilados em um banco de dados no Programa Microsoft Excel Versão 2009 e transferidos para o Programa Estatístico Graph Pad Prism (Version 3,02 for Windows, Graph Pad Software, San Diego, Ca, USA). Primeiramente realizou-se o teste estatístico não paramétrico MannWitney para comparação entre dois grupos independentes e posteriormente foi aplicado o Teste de Kruskal-Wallis, para comparações múltiplas a fim de se verificar a qualidade da água, nas diferentes regiões do município, relacionada às características físicas, químicas e microbiológicas. 
5. RESULTADOS E DISCUSSÃ̃ 
Neste estudo foram avaliadas as condições microbiológicas e físicoquímicas da água armazenada em reservatórios domésticos e de UBSs. As edificações brasileiras, frequentemente, apresentam um sistema misto para as instalações hidráulicas, constituídas por ramais de distribuição e reservatórios de água (BOTELHO; RIBEIRO Jr, 2007), os quais devem garantir, qualitativa e quantitativamente, o consumo de água adequada.

Os reservatórios mais antigos são confeccionados em amianto. Segundo informações da maior produtora de soluções para armazenamento de água do Brasil, na atualidade, os reservatórios de polietileno e polipropileno são os mais utilizados, por serem considerados os sintéticos mais duráveis e leves disponíveis, ganhando a preferência do consumidor (FORTLEV, 2011).

Os reservatórios geralmente são mantidos sob o telhado das casas, possuem tampas e garantem uma quantidade de água suficiente ao domicílio, mesmo durante os períodos de intermitência no serviço de abastecimento. A distribuição da água, armazenada nas denominadas caixas d'água, não requer a utilização de objetos ou contato com as mãos, diminuindo os riscos de contaminação da água a ser consumida.

Previamente ao início das coletas de amostras de água nos 217 domicílios sorteados aleatoriamente para o estudo, foram feitas observações sobre a limpeza e manutenção dos reservatórios domésticos de água em 78 domicílios localizados no município de Ribeirão Preto-SP. O levantamento norteou os procedimentos metodológicos.

A seguir, são apresentados os resultados obtidos a partir das observações das condições dos reservatórios domésticos de água e também das análises laboratoriais propostas para atingir os objetivos deste estudo.

\subsection{Limpeza e manutenção dos reservatórios domiciliares de água}

Os resultados deste levantamento revelaram que os moradores (97\%) têm conhecimento da existência de um reservatório de água em seus domicílios e da necessidade de limpeza (86\%), porém, há um esquecimento 
sobre o período correto em que esta limpeza deve ser realizada, uma vez que não são mantidos registros dos procedimentos de higienização dos reservatórios, na maioria das casas.

No que diz respeito à freqüência adequada para limpeza do reservatório de água, 53\% dos participantes assinalaram o período correto de 6 meses, que é o intervalo sugerido para evitar o acúmulo de sedimentos no fundo do reservatório, de acordo com as recomendações da FUNASA (BRASIL, 2006). Segundo essa Instituição, a limpeza neste período, possibilita a remoção do biofilme, o qual se caracteriza em um complexo ecossistema microbiano que se adere às paredes internas do reservatório.

Em relação à limpeza do reservatório do domicílio, apenas 12\% afirmou realizá-la a cada seis meses. Dentre os outros, 1\% afirmou nunca tê-la realizado; $41 \%$ a realizou há dois anos; $8 \%$ há um ano e $38 \%$ não soube responder, afirmando ter alugado o imóvel recentemente.

As informações sobre a manutenção do reservatório evidenciaram uma condição relevante, uma vez que somente (12\%) dos participantes afirmaram realizar a limpeza no período de 6 meses (Figura 25). 


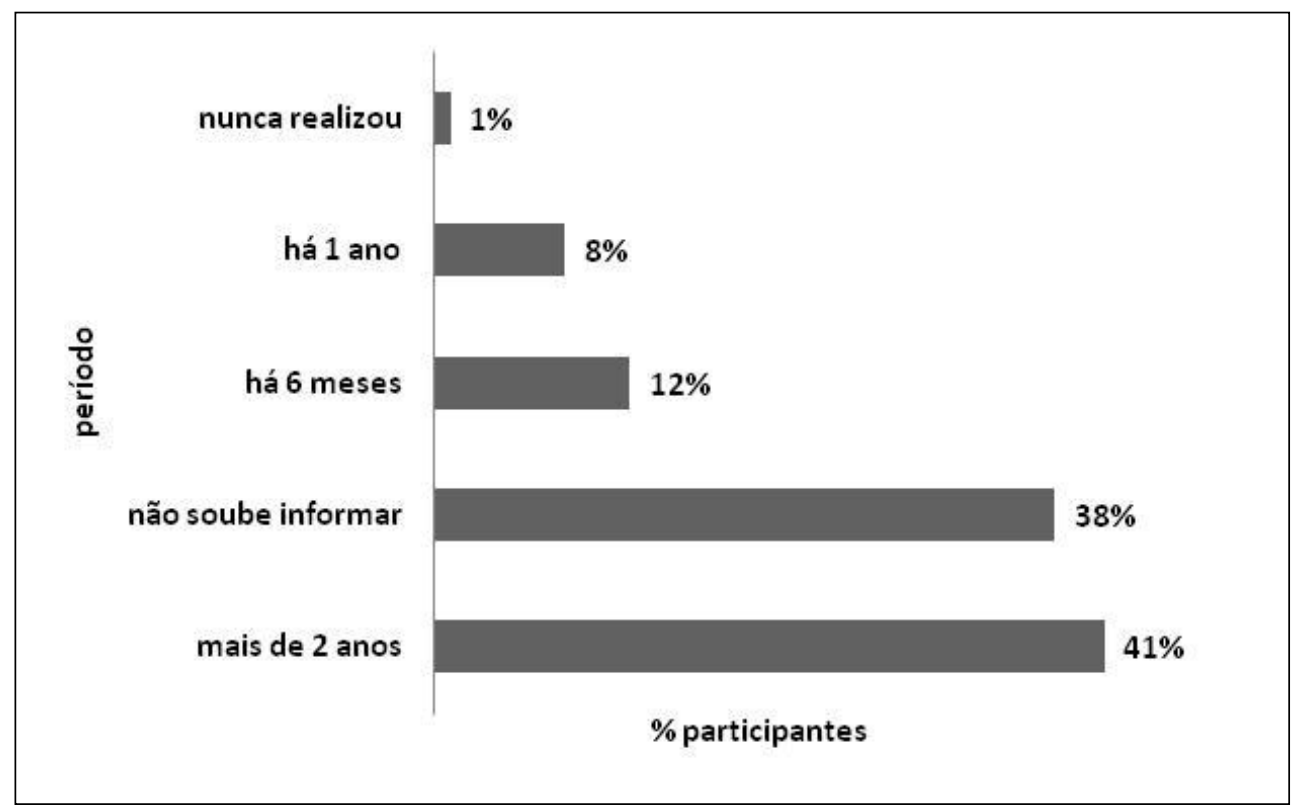

Figura 25 - Distribuição da frequência dos períodos de limpeza do reservatório domiciliar de água, de acordo com as informações fornecidas pelos participantes $(n=78)$.

Quando questionados sobre os objetos e produtos considerados adequados à limpeza do reservatório, 82\% selecionaram a água, o cloro e a escova de fibra como material apropriado para a manutenção do local destinado ao armazenamento da água (Figura 26). 


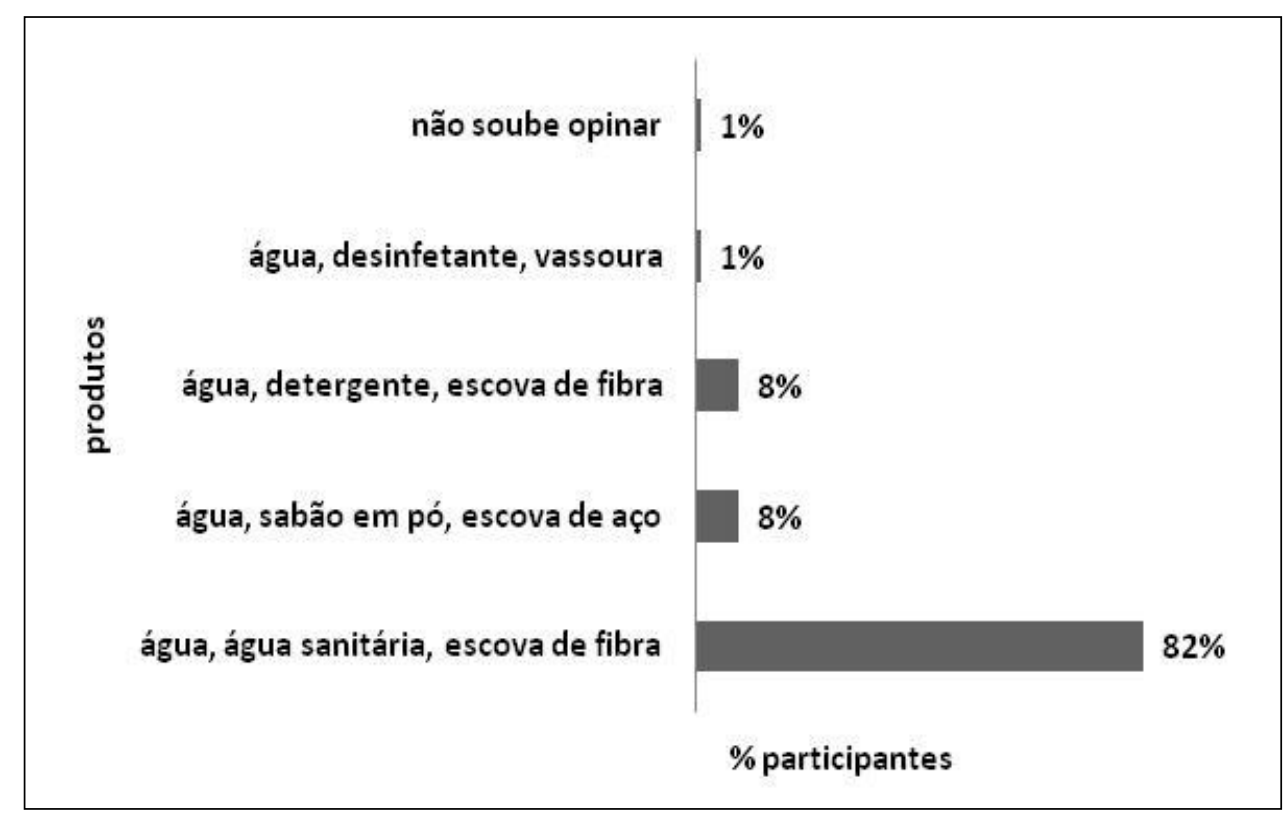

Figura 26 - Produtos e objetos considerados adequados para limpeza do reservatório domiciliar de água, de acordo com os participantes $(n=78)$.

Foi preocupante constatar que $17 \%$ dos participantes indicaram objetos inadequados e produtos químicos considerados impróprios, os quais podem causar corrosão, ocasionando a fixação de impurezas e de resíduos no reservatório, contaminando a água (BRASIL, 2006), a exemplo de detergentes, desinfetantes, sabões e do aço utilizado em escovas, o qual poderá provocar ranhuras na parede do reservatório liberando partículas na água e propiciando a proliferação de microrganismos nestes locais.

Produtos como sabão em pó, desinfetantes e detergentes são fabricados com a utilização de diversas substâncias químicas (amônia, hidróxido de sódio, surfactantes, isotiazolinonas, formaldeídos, etc.) que podem ocasionar alergias, eczemas, asma e outros problemas de saúde (CORRÊA, 2005).

De acordo com o observado em $63 \%$ destes domicílios, o banheiro e a cozinha foram os cômodos da casa associados aos reservatórios de água domésticos (Figura 27). Vale ressaltar a importância da correta limpeza e dos 
períodos de manutenção, pois estes cômodos relacionam-se com atividades de higiene pessoal e do ambiente doméstico, bem como a manipulação e preparo dos alimentos, além de ingestão direta de água pelos moradores.

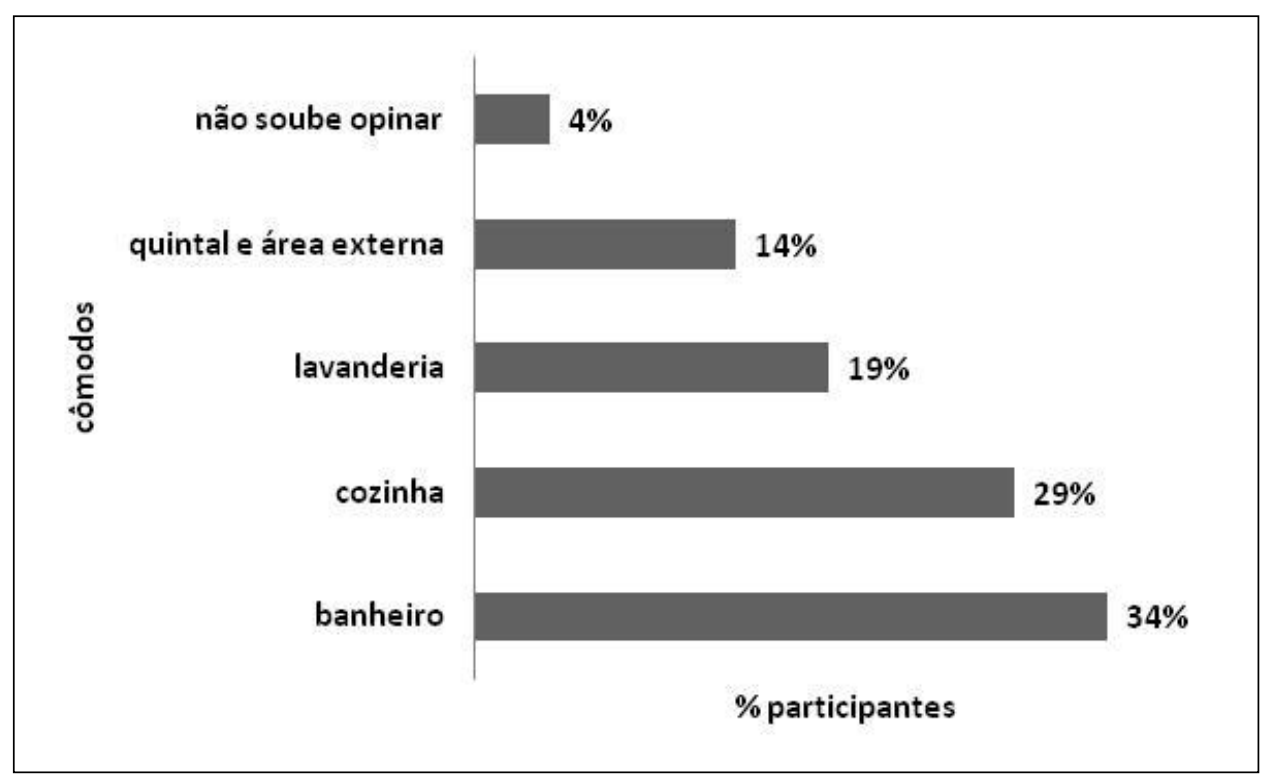

Figura 27 - Cômodos do domicílio que recebem água diretamente do reservatório domiciliar, de acordo com os participantes $(n=78)$.

Quase todos os moradores (95\%) consideraram que a água fornecida pelo sistema de distribuição é de boa qualidade, porém, 55\% a utilizam para ingestão direta, desconsiderando o uso de filtros e de água mineral engarrafada.

Alguns autores constataram que a população não confia na qualidade da água que chega às suas residências, levando-os a consumirem água mineral engarrafada para a ingestão direta, utilizando a água da torneira para a higiene e limpeza doméstica. Os estudos revelam esta prática, principalmente entre as populações de norte-americanos, canadenses e franceses (DORIA, 2006; ABRAHAMS et al., 2000).

Assim como observado em outros estudos (DORIA, 2006; SMITH; KOMOS, 2009), um dos fatores que contribuem para o consumo de água engarrafada é a insatisfação com as características organolépticas, 
principalmente o sabor da água proveniente das torneiras domésticas. O Brasil ocupa a quarta posição no mercado mundial em consumo de água mineral engarrafada (RODWAN Jr., 2010), pois em nossa sociedade, existe a percepção de que este consumo representa um estilo de vida saudável e que estes produtos são relativamente mais seguros (SANT'ANA et al., 2003) quando comparados à água que chega diretamente às torneiras das residências.

Após a finalização do levantamento, procedeu-se a realização das coletas de amostras de água dos reservatórios domiciliares $(n=217)$ e das UBSs $(n=23)$, conforme proposto inicialmente, realizando a verificação da qualidade microbiológica e físico-química da água utilizada para consumo humano.

\subsection{Análise bacteriológica}

A análise de indicadores bacterianos na água é um método bastante sensível e específico. O Grupo Coliformes e a Escherichia coli têm sido recomendados como importantes indicadores da qualidade da água a ser consumida. Na Tabela 1 são apresentados os resultados obtidos para a análise bacteriológica das amostras de água do presente estudo.

Tabela 1 - Resultados da análise bacteriológica obtidos em amostras de água de domicílios ( $n=217)$ e UBSs $(n=23)$, no município de Ribeirão Preto, a partir da Técnica de Tubos Múltiplos com substrato cromogênico.

\begin{tabular}{ccc}
\hline $\begin{array}{c}\text { Amostras } \\
(\mathbf{n})\end{array}$ & $\begin{array}{c}\text { Coliformes totais } \\
\left({ }^{*} \mathrm{NMP} / \mathbf{1 0 0} \mathrm{mL}\right)\end{array}$ & $\begin{array}{c}\text { Escherichia coli } \\
\left({ }^{*} \mathrm{NMP} / \mathbf{1 0 0} \mathrm{mL}\right)\end{array}$ \\
\hline Domicílios & $<1,8$ & $<1,8$ \\
\hline 217 & & $<1,8$ \\
\hline UBSs & $<1,8$ & \\
\hline 23 & & \\
\hline${ }^{*} \mathrm{NMP}$ - Número Mais Provável por $100 \mathrm{~mL}$ & & \\
\hline
\end{tabular}


Em todas as amostras, incluindo domicílios $(n=217)$ e UBSs $(n=23)$, observamos um resultado esperado para água potável (Figura 28) em relação ao Número Mais Provável (NMP) para bactérias do Grupo Coliformes. Todas as amostras apresentaram NMP $<1,8$.

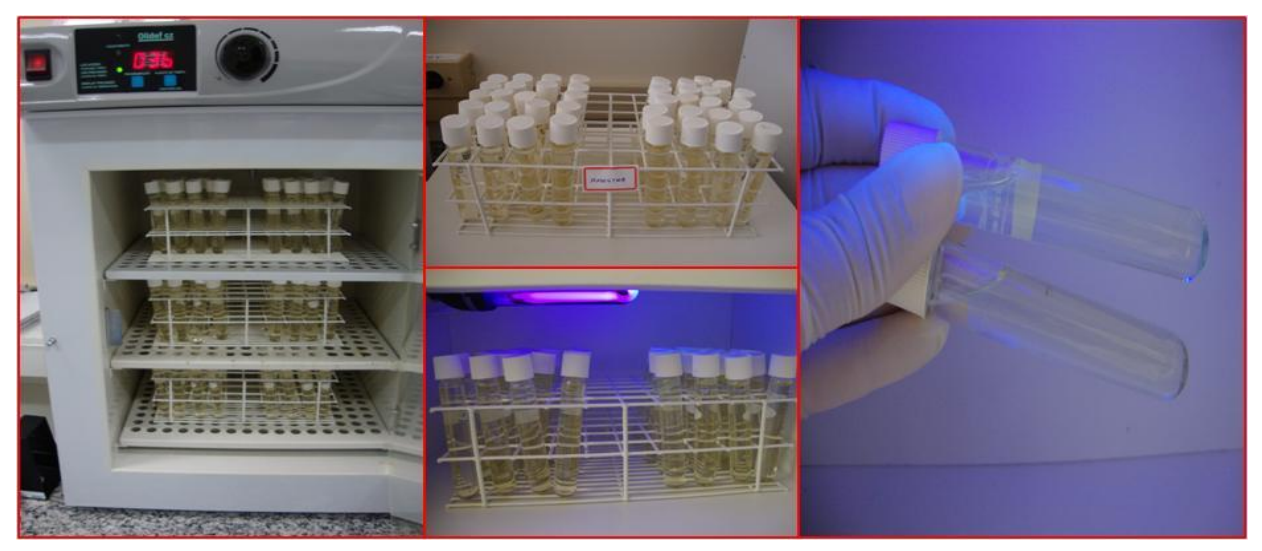

Figura 28 - Leitura do resultado de análise bacteriológica de amostras de água, utilizando-se a câmara de luz ultravioleta $(366 \mathrm{~nm}, 6 \mathrm{~W})$ após permanecerem armazenadas em estufa de cultura a $35 \pm 0,5^{\circ} \mathrm{C}$, durante $24 \pm 2$ horas. Fonte: Julião, F.C. (2010).

Alguns fatores podem justificar os bons resultados obtidos para a análise bacteriológica das amostras de água deste estudo. Conforme afirmam alguns autores, a qualidade da água do manancial, a eficiência do tratamento no sistema de distribuição e o correto armazenamento doméstico, são ações que garantem a adequada qualidade da água no momento do consumo (WRIGHT et al., 2004; CONCEIÇÃO et al., 2009).

Para este estudo observamos que os fatores citados podem ser associados à qualidade da água analisada, uma vez que o município é abastecido com água proveniente do Aquifero Guarani, que após a captação recebe a adição de cloro e flúor e nos domicílios pode ter uso direto ou permanecer armazenada em reservatórios de água.

Em Ribeirão Preto, local deste estudo, a água é captada diretamente dos poços artesianos que abastecem o município com a água proveniente do Aquifero Guarani, a qual apresenta uma ótima qualidade desde o local de 
captação até o ponto de consumo. Segundo Conceição et al. (2009), a água subterrânea apresenta excelente qualidade e disponibilidade, permitindo a sua utilização para consumo humano sem tratamento prévio.

O declínio na qualidade da água, entre a fonte de abastecimento e o ponto de consumo, considerando-se a contaminação por bactérias do grupo coliformes é proporcionalmente maior quando a água é captada de mananciais já contaminados, normalmente os superficiais (WRIGHT et al., 2004), muito comum em grandes áreas urbanas, porém não utilizados em Ribeirão Preto, uma vez que o município é 100\% abastecido com água subterrânea.

Segundo Wright et al. (2004), a porcentagem de contaminação da água armazenada nos domicílios diminui quando a mesma encontra-se em reservatório protegido e adequado para esta reserva, pois em recipientes abertos, a água torna-se vulnerável à contaminação, uma vez que, nestes locais existe a necessidade de um manejo com objetos a serem mergulhados para captação da água.

Durante a coleta de amostras de água nos domicílios, foi possível observar que os reservatórios domésticos localizavam-se sob o telhado, protegidos do intemperismo, caracterizando-se como locais adequados para o armazenamento de água. Os resultados obtidos revelaram que a água proveniente dos reservatórios domésticos, em Ribeirão Preto, no que diz respeito à condição bacteriológica, segue os padrões estabelecidos para a potabilidade.

Os ótimos resultados obtidos para os reservatórios que tiveram a água analisada não representam uma realidade para as moradias de grande parte da população brasileira, considerando-se o número de favelas e de outros locais onde não existe, ou é precária a condição de abastecimento de água.

Vale lembrar que os locais de coleta foram escolhidos a partir do sorteio dos setores censitários, que considera um número de domicílios onde é possível levantar informações, ou seja, não foram incluídos na amostragem moradias dos denominados aglomerados subnormais, caracterizados por 
construções precárias e carentes de serviços públicos essenciais, mais comumente chamados de favelas.

Em estudo de Julião (2003), também realizado no município de Ribeirão Preto, foi possível verificar que nas moradias dos aglomerados subnormais a água é armazenada em recipientes plásticos ou latões e manuseada com a utilização de objetos, deixando-a expostas a contaminantes físicos, químicos e biológicos, tornando-a imprópria ao consumo, deixando a população vulnerável ao risco de adoecimento por doenças infecto-parasitárias.

Apesar do relatado, casos de contaminação da água intra-domiciliar ocorrem não só em moradias com condições precárias, mas também naquelas onde existe um reservatório adequado. Alguns autores apresentam resultados de contaminação da água nos reservatórios domésticos em localidades das regiões sudeste e nordeste do país, conforme descrito a seguir.

Uma investigação realizada por Lunardão e Soares (2006) no município de Lins-SP, indicou a contaminação da água em 95 residências de um total de 140, representando um índice de $67,86 \%$ de resultados positivos para a presença de coliformes totais e termotolerantes na água armazenada em reservatórios domiciliares.

Também em Umuarama-PR, concluiu-se que a falta de manutenção e limpeza dos reservatórios domiciliares não estava associada à falta de informação, pois os entrevistados afirmaram ter conhecimento sobre a necessidade de limpeza dos reservatórios, no entanto, a água apresentou contaminação após passar pelo reservatório doméstico. Os autores ressaltaram que na cidade a informação sobre a importância da limpeza da caixa d'água, sempre foi destacada no rodapé das notas para pagamento da água, no entanto, não é realizada devido à falta de hábito da população (DARCI BOM, 2002).

Em Mossoró-RN, a água consumida pelos moradores estava imprópria, segundo um levantamento de 2005, o qual relatou que $97 \%$ dos reservatórios domiciliares, que tiveram amostras de água analisadas, armazenavam água 
com padrão de potabilidade insatisfatório, de acordo com o estabelecido pelo Ministério da Saúde (SIBÉRIA, 2006).

Da mesma forma, em Salvador-BA, pesquisadores do Departamento de Engenharia Ambiental da Escola Politécnica da Universidade Federal da Bahia (UFBA), coletaram e analisaram 5.548 amostras de água em 320 casas de 34 áreas da capital baiana em duas etapas: 1997/1998 e 2002/2003. A pesquisa revelou que a água, após passar pelo armazenamento e tubulação domiciliar, chega a apresentar um grau de contaminação até sete vezes superior ao da água da empresa responsável pelo abastecimento hídrico no município (PORTAL APRENDE BRASIL, 2007).

Durante a coleta de amostras de água para este estudo, foi possível verificar que em todos os domicílios havia no mínimo um reservatório doméstico. Conforme citado anteriormente, alguns estudos realizados em outros países revelaram que ocorre contaminação da água no local de armazenamento, porém deve-se considerar que as formas de armazenamento domiciliar são mais precárias quando comparadas às caixas d'água utilizadas em parcela significativa dos domicílios brasileiros.

Em Bangladesh investigaram a associação entre a qualidade da água e as práticas de manejo adotadas pela população. Os pesquisadores constataram que as amostras de água provenientes dos locais de armazenamento doméstico, apresentaram um alto índice de contaminação representado por $73 \%$ das 270 amostras analisadas (HOQUE et al., 2006).

Assim como em pesquisa realizada no Sudão, foi constatado que ocorria contaminação da água por coliformes, acima dos limites aceitos pela WHO, não só nas fontes de água para abastecimento da população nômade, mas também nos locais de armazenamento utilizados pela população residente em áreas periurbanas (MUSA et al., 1999).

Da mesma forma, no sul da Índia, a contaminação da água durante o armazenamento doméstico é a maior causa de transmissão de infecções entéricas, principalmente ocasionadas por bactérias (BRICK et al., 2004). 
No México, comunidades do sudeste do país improvisam a infraestrutura para água e esgoto. Na cidade de Culiacan, uma pesquisa revelou a contaminação por coliformes totais e termotolerantes em $46 \%$ das 100 amostras de água analisadas provenientes de torneiras domésticas e revelou a necessidade de tratamento adicional para a água dos domicílios antes do consumo, visando diminuir a exposição à doenças de veiculação hídrica (CHAIDEZ et al., 2008).

As pesquisas citadas revelam que, frequentemente, a contaminação ocorre durante o armazenamento da água nos domicílios, indicando a necessidade da participação coletiva para minimizar os efeitos negativos da ingestão de água com a qualidade comprometida por contaminantes de origem física, química ou biológica, evitando-se riscos à saúde da população.

Apesar dos resultados obtidos em diferentes estudos, vale ressaltar que a qualidade da água a ser consumida nos domicílios depende, não só das ações da população, mas também da qualidade da água do manancial, da eficiência do sistema de distribuição e da manutenção correta e periódica dos reservatórios domésticos apropriados para o armazenamento da água.

\subsection{Análise Parasitológica}

As enfermidades parasitárias intestinais têm se destacado dentre os diversos fatores que acometem a saúde humana. As primitivas condições sanitárias e ambientais permitem a disseminação de doenças de veiculação hídrica, a partir da ausência de cuidados com o manejo e armazenamento da água utilizada para consumo.

Na Tabela 2 constam os resultados das análises parasitológicas obtidos neste estudo. Em todas as amostras analisadas, provenientes dos domicílios $(n=217)$ e UBSs $(n=23)$ selecionados para o estudo, não foi detectada a presença de ovos, cistos e larvas de parasitas. 
Tabela 2 - Resultados da análise parasitológica obtidos em amostras de água de domicílios ( $n=217)$ e UBSs ( $n=23)$ no município de Ribeirão Preto, a partir de sedimentação espontânea com posterior análise na Câmara de Sedgewick-Rafter.

\begin{tabular}{|c|c|}
\hline Amostras (n) & Ovos, cistos e larvas de parasitas ${ }^{*}$ \\
\hline \multicolumn{2}{|c|}{ Domicílios } \\
\hline 217 & $\mathrm{ND}^{* *}$ \\
\hline \multicolumn{2}{|c|}{ UBSs } \\
\hline 23 & $\mathrm{ND}^{* *}$ \\
\hline $\begin{array}{l}{ }^{\circ} \text { Parasitas pesquisados: Ancyl } \\
\text { Strongyloides stercoralis. } \\
{ }_{\star \star} \text { ND - Não Dectável. }\end{array}$ & histolytica; Entamoeba coli; Hymenolepis sp. \\
\hline
\end{tabular}

Durante as coletas, as amostras de água foram obtidas diretamente da torneira da cozinha que fornece água do reservatório doméstico a partir de instalação hidráulica composta por canos de Poli Cloreto de Vinila (PVC). Este reservatório é mantido, geralmente, sob o telhado da casa, possui tampa e é confeccionado com material apropriado para o armazenamento da água. Portanto, a água pode ser fornecida ao domicílio, sem a necessidade de utilização de objetos e contato com as mãos.

Alguns fatores, citados anteriormente para a análise bacteriológica, podem ter colaborado também para a ausência de ovos, cistos e larvas de parasitas nas amostras de água analisadas. A água que chega aos domicílios é captada em poços artesianos e passa por um processo de cloração antes de ser distribuída ao município. Após a distribuição, a água permanece armazenada nos reservatórios, os quais, nos domicílios apresentavam boas condições de manutenção, estando protegidos do intemperismo, possuindo tampas e localizados sob o telhado.

Nas UBSs, os reservatórios possuem uma construção diferenciada uma vez que armazenam um volume maior de água, porém uma empresa contratada pela prefeitura municipal realiza a limpeza dos mesmos a cada 6 meses, mantendo estes locais adequados ao armazenamento da água, garantindo não só os padrões de potabilidade, mas também a qualidade necessária para a sua utilização nos serviços de saúde. 


\subsection{Análise de metais}

O excesso ou a deficiência de alguns metais podem prejudicar a saúde humana e os efeitos incluem alguns tipos de câncer, problemas no aparelho reprodutivo, doenças cardiovasculares e neurológicas (RAJARATNAM et al., 2001). Os seres humanos podem estar expostos a metais a partir de várias fontes e a água representa uma das principais vias de contaminação, talvez por isso seja crescente a preocupação com a água de boa qualidade, desde o manancial até o ponto de consumo (CHAKRABARTY; SARMA, 2010).

A seguir (Tabela 3 e Figura 29), são apresentados os valores das concentrações dos metais $\mathrm{Cr}$; $\mathrm{Cu}$; $\mathrm{Mn}$; $\mathrm{Ni} ; \mathrm{Pb}$ e $\mathrm{Zn}$ nas amostras de água analisadas e também os valores de referência recomendados na Portaria 518/2004 (Brasil, 2004) e no Guidelines for Drinking Water Quality (WHO, 2004). As concentrações dos metais As; Be; Ca; Fe; Hg; $\mathrm{Sn}$; $\mathrm{Tl}$ e V apresentaram-se abaixo dos limites de detecção do aparelho, descritos na seção de materiais e métodos; motivo pelo qual os valores não constam nas tabelas. Os valores na Tabela 3 foram extraídos dos dados apresentados no Apêndice C. 
Tabela 3 - Concentração de metais (mg/L) em amostras de água analisadas ( $n=427)$, provenientes de reservatórios domiciliares, de UBSs e da rede de abastecimento público, no município de Ribeirão Preto-SP.

\begin{tabular}{|c|c|c|c|c|c|c|}
\hline \multicolumn{7}{|c|}{ Água do reservatório } \\
\hline & & & tais $(\mathrm{mg}$ & & & \\
\hline & $\mathrm{Cr}$ & $\mathrm{Cu}$ & Mn & $\mathrm{Ni}$ & $\mathrm{Pb}$ & $\mathrm{Zn}$ \\
\hline Média & 0,0015 & 0,0629 & 0,0010 & 0,0016 & 0,0026 & 0,1396 \\
\hline Desvio padrão & 0,0019 & 0,1840 & 0,0035 & 0,0029 & 0,0043 & 0,5797 \\
\hline Mediana & 0,0014 & 0,0154 & 0,0004 & 0,0007 & 0,0014 & 0,0464 \\
\hline Mínimo & 0,0002 & 0,0012 & 0,0000 & 0,0001 & 0,0001 & 0,0061 \\
\hline Máximo & 0,0246 & 1,5391 & 0,0427 & 0,0197 & 0,0368 & 7,8591 \\
\hline \multicolumn{7}{|c|}{ Água da rede de abastecimento } \\
\hline \multicolumn{7}{|c|}{ Metais $(\mathrm{mg} / \mathrm{L})$} \\
\hline & $\mathrm{Cr}$ & $\mathrm{Cu}$ & Mn & $\mathbf{N i}$ & $\mathbf{P b}$ & Zn \\
\hline Média & 0,0012 & 0,0764 & 0,0008 & 0,0027 & 0,0050 & 0,1538 \\
\hline Desvio padrão & 0,0012 & 0,2082 & 0,0012 & 0,0063 & 0,0106 & 0,2965 \\
\hline Mediana & 0,0013 & 0,0153 & 0,0005 & 0,0009 & 0,0015 & 0,0506 \\
\hline Mínimo & 0,0002 & 0,0010 & 0,0000 & 0,0001 & 0,0002 & 0,0068 \\
\hline Máximo & 0,0075 & 2,1527 & 0,0096 & 0,0615 & 0,0591 & 1,9873 \\
\hline Brasil $^{*}$ & 0,05 & 2 & 0,1 & ------- & 0,01 & 5 \\
\hline $\mathrm{WHO}^{* *}$ & 0,05 & 2 & 0,4 & 0,07 & 0,01 & 3 \\
\hline
\end{tabular}


$\mathrm{Cr}$

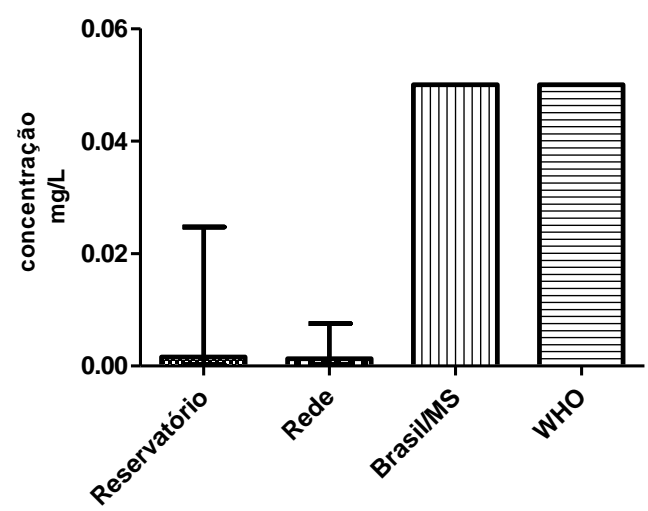

$\mathrm{Mn}$
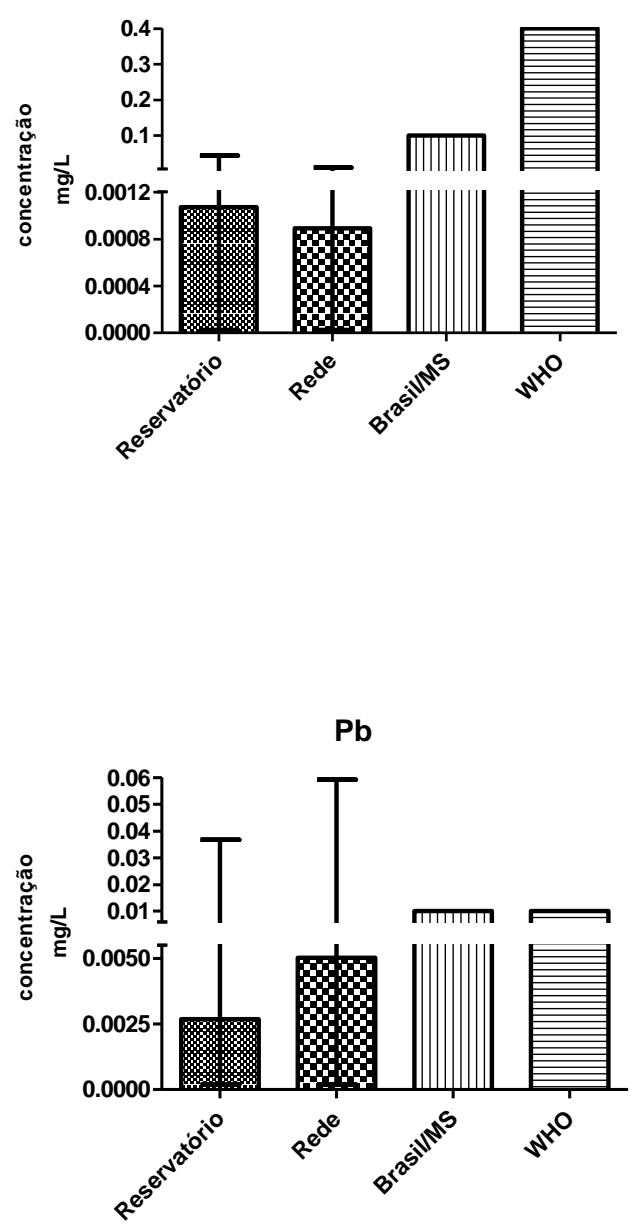

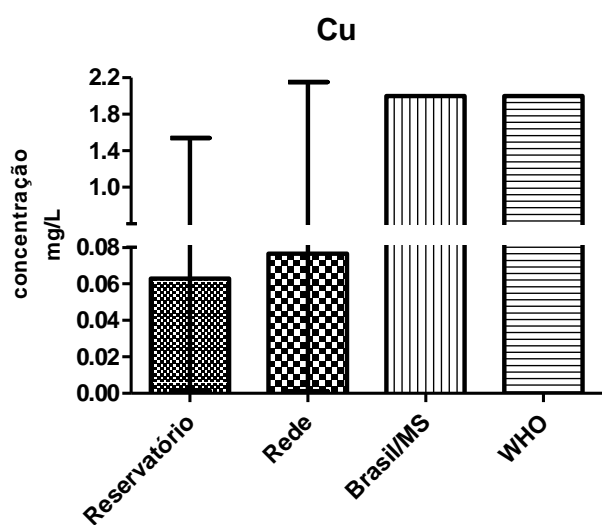

Ni

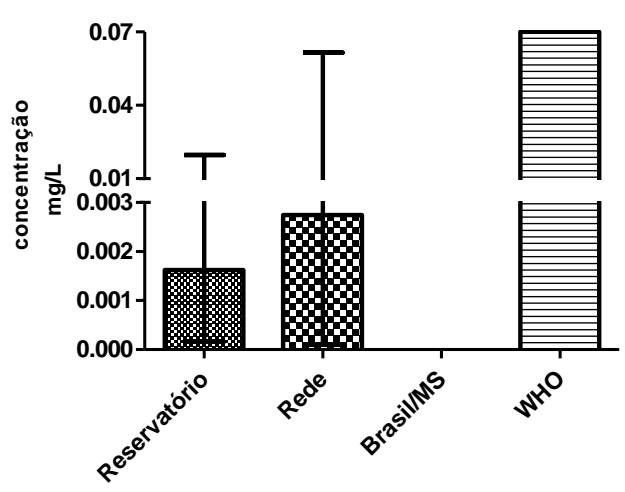

Zn

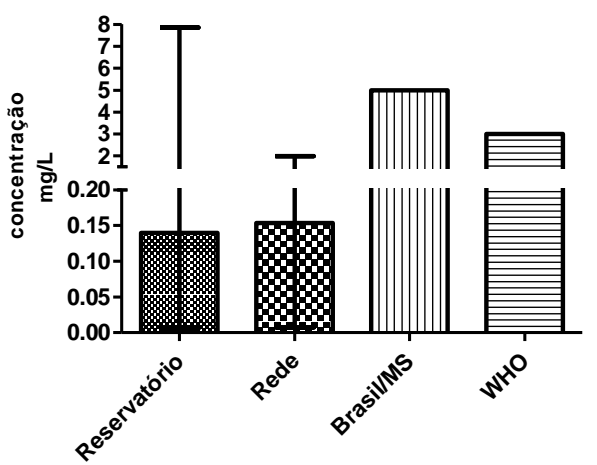

Figura 29 - Concentração de $\mathrm{Cr}, \mathrm{Cu}, \mathrm{Mn}, \mathrm{Ni}, \mathrm{Pb}$ e $\mathrm{Zn}$ nas amostras de água provenientes dos reservatórios e da rede de abastecimento público no município de Ribeirão Preto,SP. 
Os valores revelam que as concentrações médias dos metais em todas as amostras analisadas estão de acordo com os níveis recomendados pela Portaria 518/2004 e pela Organização Mundial da Saúde.

Conforme observado, as concentrações de metais nas amostras coletadas, tanto nos reservatórios, quanto nos pontos da rede de abastecimento direto, mantêm-se de acordo com os padrões estabelecidos na legislação, apresentando níveis bem inferiores ao limite recomendado, não representando motivo de preocupação no que diz respeito à presença desses metais na água consumida nos locais amostrados.

Alguns dos valores máximos para as concentrações de $\mathrm{Cu}, \mathrm{Pb}$ e $\mathrm{Zn}$ apresentaram-se pouco acima do limite recomendado, no entanto, tratam-se de dados isolados, levando em conta que unicamente 1 amostra da rede apresentou concentrações de $\mathrm{Cu}$ acima de $2 \mathrm{mg} / \mathrm{L} ; 7$ amostras de água de reservatórios e 13 amostras da rede apresentaram concentrações de $\mathrm{Pb}$ superiores a 0,01 mg/L e para Zn uma única amostra de reservatório de água apresentou concentrações acima das recomendadas.

Estes resultados podem ser justificados pelo tempo de estagnação da água dentro dos reservatórios, conforme revelado em estudos internacionais (SHOCK; NEFF,1988; LYTLE; SCHOCK, 2000; MERKEL et al., 2002), onde as concentrações destes metais estavam elevadas após algumas horas sem utilização da água do reservatório doméstico. Para RAJARATNAM et al. (2002), o período de até 6 horas de estagnação é considerado o mais aceitável para a minimização dos riscos decorrentes à exposição a metais presentes na água.

O aumento na concentração de $\mathrm{Zn}$ pode ocorrer devido aos efeitos de corrosão do material galvanizado utilizado na estrutura hídrica da rede pública de abastecimento e armazenamento da água, provocando uma dissolução deste metal na água (JAWAD et al., 1988; ZIADAT, 2005; RAJARATNAM et al., 2002).

Durante a coleta de amostras foi possível verificar em $61 \%$ dos domicílios visitados que os principais materiais dos reservatórios foram 
amianto (32\%) e polietileno 29\%. Em 85 domicílios (39\%) não foi obtida essa informação.

Os dados das concentrações de metais foram organizados de acordo com o material de fabricação do reservatório e comparados estatisticamente (Tabela 4). Após a aplicação do Teste Estatístico Mann-Whitney (Apêndice D), observou-se que não houve diferença estatisticamente significante entre os níveis de metais detectados para a água armazenada segundo o tipo de material do reservatório.

Vale ressaltar que apesar dos resultados não indicarem aumento nas concentrações de metais na água armazenada nos reservatórios de amianto, esse material teve sua utilização discutida e até proibida em vários países, por estar relacionado a diversas patologias, inclusive câncer de pulmão como risco ocupacional (CASTRO; GIANNASI; NOVELLO, 2003). No Brasil, os reservatórios mais antigos, fabricados com amianto, têm sido gradativamente substituídos por outros de polietileno ou fibra de vidro.

Tabela 4 - Concentração de metais (mg/L) em amostras de água analisadas $(n=217)$ segundo o material do reservatório de água (amianto e polietileno).

\begin{tabular}{|c|c|c|c|c|c|c|}
\hline \multicolumn{7}{|c|}{ Reservatório de amianto } \\
\hline \multicolumn{7}{|c|}{ Metais ( $\mathrm{mg} / \mathrm{L}$ ) } \\
\hline & $\mathrm{Cr}$ & $\mathrm{Cu}$ & $\mathrm{Mn}$ & $\mathrm{Ni}$ & $\mathrm{Pb}$ & $\mathrm{Zn}$ \\
\hline Média & 0,0016 & 0,0756 & 0,0010 & 0,0021 & 0,0031 & 0,1838 \\
\hline Desvio padrão & 0,0013 & 0,1858 & 0,0027 & 0,0036 & 0,0054 & 0,4790 \\
\hline Mediana & 0,0015 & 0,0215 & 0,0006 & 0,0010 & 0,0017 & 0,0546 \\
\hline Mínimo & 0,0003 & 0,0025 & 0,0001 & 0,0003 & 0,0003 & 0,0120 \\
\hline Máximo & 0,0059 & 0,9784 & 0,0244 & 0,0191 & 0,0368 & 3,1745 \\
\hline \multicolumn{7}{|c|}{ Reservatório de polietileno } \\
\hline \multicolumn{7}{|c|}{ Metais ( $\mathrm{mg} / \mathrm{L}$ ) } \\
\hline & $\mathrm{Cr}$ & $\mathrm{Cu}$ & $\mathrm{Mn}$ & $\mathbf{N i}$ & $\mathrm{Pb}$ & $\mathrm{Zn}$ \\
\hline Média & 0,0018 & 0,1209 & 0,0015 & 0,0017 & 0,0040 & 0,2291 \\
\hline Desvio padrão & 0,0033 & 0,2858 & 0,0055 & 0,0029 & 0,0053 & 1,0015 \\
\hline Mediana & 0,0013 & 0,0316 & 0,0005 & 0,0010 & 0,0021 & 0,0651 \\
\hline Mínimo & 0,0003 & 0,0033 & 0,0000 & 0,0002 & 0,0002 & 0,0109 \\
\hline Máximo & 0,0247 & 1,5392 & 0,0428 & 0,0197 & 0,0299 & 7,8592 \\
\hline Brasil $^{*}$ & 0,05 & 2 & 0,1 & ------ & 0,01 & 5 \\
\hline WHO** & 0,05 & 2 & 0,4 & 0,07 & 0,01 & 3 \\
\hline
\end{tabular}

*Valores Máximos Permitidos (VMP) - Portaria 518/2004 do Ministério da Saúde (Brasil, 2004).

${ }^{\star *}$ Guidelines for drinking water quality - World Health Organization (WHO, 2004). 
Os dados também foram agrupados de acordo com as cinco regiões do município de Ribeirão Preto-SP, com a finalidade de evidenciar se existia variação espacial na concentração de metais na água analisada por região.

$\mathrm{Na}$ Tabela 5 são apresentados os resultados das concentrações de metais nas amostras $(n=427)$ segundo a região de coleta (Centro, Norte, Sul, Leste e Oeste).

Tabela 5 - Concentração média de metais $(\mathrm{mg} / \mathrm{L})$ em amostras de água analisadas $(n=427)$ segundo a localização por região no município de Ribeirão Preto-SP.

\begin{tabular}{l|cccccc}
\hline \multirow{2}{*}{ Regiões } & \multicolumn{6}{c}{ Valor médio das concentrações de metais (mg/L) } \\
\cline { 2 - 6 } Centro & $\mathbf{C r}$ & $\mathbf{C u}$ & $\mathbf{M n}$ & $\mathbf{N i}$ & $\mathbf{P b}$ & $\mathbf{Z n}$ \\
Norte & 0,0010 & 0,0077 & 0,0004 & 0,0004 & 0,0008 & 0,0428 \\
Sul & 0,0019 & 0,0569 & 0,0010 & 0,0018 & 0,0030 & 0,0908 \\
Leste & 0,0011 & 0,0830 & 0,0012 & 0,0031 & 0,0048 & 0,2788 \\
Oeste & 0,0012 & 0,1134 & 0,0013 & 0,0027 & 0,0052 & 0,1918 \\
\hline Brasil $^{*}$ & 0,0016 & 0,0239 & 0,0006 & 0,0013 & 0,0023 & 0,0689 \\
WHO $^{* *}$ & $\mathbf{0 , 0 5}$ & $\mathbf{2}$ & $\mathbf{0 , 1}$ & $-\cdots$ & $\mathbf{0 , 0 1}$ & $\mathbf{5}$ \\
\hline
\end{tabular}

* Valores Máximos Permitidos (VMP) - Portaria 518/2004 do Ministério da Saúde (Brasil, 2004).

${ }^{\star *}$ Guidelines for drinking water quality - World Health Organization (WHO, 2004).

Após a aplicação do Teste de Kruskall Wallis complementado com o Teste de Comparações Múltiplas de Dunn (Apêndice E), foi constatado que não houve diferença estatisticamente significante entre a concentração dos metais nas diferentes regiões. Ou seja, nenhuma região apresentou padrões característicos nas concentrações de metais que evidenciassem uma tendência espacial segundo a localização dos domicílios no município.

Muitas investigações em diferentes partes do mundo (CHAKRABARTY; SARMA, 2010; VÖLKER et al., 2010; ZIETZ et al., 2010; BORAH et al., 2009; DAS et al., 2009; SIA SU, 2007; JALEEL et al., 2001) reportaram a contaminação por metais tóxicos, na água para consumo humano, relacionada principalmente ao tempo de estagnação da água no reservatório doméstico e também à sedimentação de material dentro do reservatório, onde a deposição 
de matéria orgânica e sedimentos alcançaram $1 \mathrm{~cm}$ de espessura (ZIADAT, 2005).

No entanto, neste estudo os resultados revelaram uma condição satisfatória e adequada da água analisada no que se refere à concentração de metais. A água analisada no município de Ribeirão Preto apresentou concentrações de metais dentro dos limites recomendados pela legislação nacional e internacional, garantindo o consumo seguro para a população.

\subsection{Análise físico-química}

A qualidade da água é vulnerável às condições ambientais a qual está exposta, portanto, além da análise de parâmetros biológicos, a avaliação de parâmetros físico-químicos torna-se necessária diante da preocupação com as condições sanitárias da água a ser consumida.

Os valores observados para temperatura, $\mathrm{pH}$ e cloro (Tabela 6) das amostras de água coletadas nos domicílios $(n=217)$ e nas UBSs $(n=23)$ estavam de acordo com o estabelecido na Portaria 518/2004.

Tabela 6 - Valores de temperatura, $\mathrm{pH}$ e cloro observados nas amostras de água de reservatórios domiciliares de UBSs no município de Ribeirão Preto-SP.

\begin{tabular}{|c|c|c|c|}
\hline \multicolumn{4}{|c|}{ Reservatórios domiciliares } \\
\hline & Temperatura $\left({ }^{\circ} \mathrm{C}\right)$ & $\mathrm{pH}$ & Cloro (mg/L) \\
\hline Mínimo & 18,5 & 5,5 & 0,15 \\
\hline Máximo & 35,8 & 7,4 & 2,32 \\
\hline Média & 25,4 & 6,5 & 1,34 \\
\hline \multicolumn{4}{|c|}{ Reservatórios das UBSs } \\
\hline Mínimo & 22,3 & 6,1 & 0,41 \\
\hline Máximo & 27,8 & 7,1 & 2,39 \\
\hline Média & 24,2 & 6,6 & 1,46 \\
\hline VMP* & -.-- & $6,0-9,5$ & 2,0 \\
\hline
\end{tabular}


A temperatura média para as amostras dos reservatórios domiciliares e das UBSs foram, respectivamente, $25,4^{\circ} \mathrm{C}$ e $24,2^{\circ} \mathrm{C}$. O valor máximo de $35,8^{\circ} \mathrm{C}$ para a temperatura da água em um reservatório doméstico justifica-se pela utilização de aquecedores solares no domicílio.

Em Ribeirão Preto, a média da temperatura climática no período da coleta das amostras foi de $22,8^{\circ} \mathrm{C}$ (CIIAGRO, 2010) e segundo Conceição et al. (2009), a temperatura média nos poços artesianos onde é coletada a água que abastece o município é de aproximadamente $26^{\circ} \mathrm{C}$.

A temperatura determina vários processos químicos, físicos e biológicos que ocorrem em um sistema aquático (CONCEIÇÃO et al., 2009), portanto a observação de seus valores durante a coleta de amostras de água deve ser realizada.

O valores médios do $\mathrm{pH}$ da água das amostras de reservatórios domiciliares e das UBSs foram respectivamente, 6,5 e 6,6.

Os valores médios de $\mathrm{pH}$ das amostras dos reservatórios domiciliares e das UBSs apresentaram-se dentro do limite recomendado pela Portaria 518/2004, que estabelece a faixa ideal de pH entre 6,0 e 9,5, em toda a rede de distribuição (BRASIL, 2004).

Para o organismo humano, a exposição a valores extremos de pH, na faixa de 11,0 pode causar irritação nos olhos e pele, podendo ocasionar também, irritação gastrointestinal. Abaixo de 4,0 podem ocorrer irritações nos olhos e na faixa de 2,5 irritações irreversíveis ao epitélio (WHO, 1996).

O valor médio observado para o cloro nos reservatórios domiciliares e das UBSs, foram, respectivamente $1,34 \mathrm{mg} / \mathrm{L} \mathrm{e} \mathrm{1,46} \mathrm{mg/L.}$

O Cloro $\left(\mathrm{Cl}_{2}\right)$ é o produto químico mais utilizado na maioria das estações de tratamento de águas superficiais e subterrâneas, pois tem a capacidade de oxidar ou romper a parede celular dos microrganismos, interferindo no metabolismo, provocando um rompimento celular e consequentemente a eliminação, principalmente de bactérias (DANIEL, 2001; SOBSEY; HANDZEL; VENCZEL, 2003). 
Segundo a Portaria 518/2004, após a desinfecção para a utilização no abastecimento, a água deve conter um teor mínimo de cloro residual livre de 0,5 mg/L, sendo obrigatória a manutenção de, no mínimo, 0,2 mg/L em qualquer ponto da rede de distribuição. Recomenda-se que o teor máximo de cloro residual livre, em qualquer ponto do sistema de abastecimento, seja de 2,0 $\mathrm{mg} / \mathrm{L}$. Nas amostras de água analisadas neste estudo, observamos um valor médio de cloro residual livre de $1,34 \mathrm{mg} / \mathrm{L}$ nos reservatórios domiciliares, provável fator de inibição do crescimento e/ou eliminação de Escherichia coli na água armazenada.

Muitos estudos têm revelado que, nos domicílios, o cloro é um eficiente agente químico para descontaminação da água que permanece armazenada, no entanto, é necessário que esteja presente em níveis recomendados para não ocasionar riscos à saúde da população e ser capaz de evitar casos de diarréia, principalmente em países em desenvolvimento (THOMPSON; SOBSEY; BARTRAM, 2003). Nas amostras de água analisadas neste estudo, observou-se que a média de cloro residual manteve concentrações consideradas ideais para a descontaminação da água, não oferecendo riscos à saúde dos consumidores.

Em pontos isolados, foi possível observar concentrações para o cloro além do limite máximo recomendado; nos reservatórios de uma UBS e de um domicílio, sendo respectivamente, 2,39 mg/L e 2,32 mg/L. Nestes dois pontos de coleta a concentração de cloro na água encontrava-se acima do recomendado pela legislação, fato que pode estar associado ao horário da coleta, num momento de maior concentração de cloro, ou à localização próxima a um poço artesiano, local onde o cloro é adicionado à água.

A concentração de cloro residual livre decai ao longo do trajeto entre as estações de tratamento de água e os imóveis a serem abastecidos; havendo uma diminuição da concentração do cloro, devido às reações que ocorrem com a matéria orgânica presente na tubulação e na própria água conduzida (WHO, 2000). 
Nas amostras de água analisadas neste estudo, observamos um valor médio de cloro residual livre indicado como eficiente para a desinfecção da água, provável fator de inibição do crescimento e/ou eliminação de Escherichia coli na água armazenada, a exemplo de outros estudos (QUICK et al., 2002; SMITH; KOMOS, 2009).

Em estudo realizado por Quick et al. (2002), nos domicílios que receberam intervenção sanitária na água, com utilização do cloro, onde foram encontrados, em média, valores de $0,2 \mathrm{mg} / \mathrm{L}$ de cloro residual livre no local de armazenamento da água, as análise microbiológicas revelaram que em $80 \%$ das amostras não havia presença de Escherichia coli.

A utilização do cloro como agente químico para desinfecção, consiste em manter a proteção residual satisfatória, mesmo com estratégias variáveis de armazenamento (SMITH; KOMOS, 2009).

Vale ressaltar que em alguns países o abastecimento de água ocorre de forma direta e em algumas localidades da Ásia, África e América Latina, as moradias não possuem instalação hidráulica, portanto, a água é coletada e transportada, pelos moradores, e armazenada em diferentes recipientes dentro dos domicílios (JENSEN et al., 2002; WRIGHT et al., 2004; ONU, 2008; RUFENER et al., 2010).

O armazenamento da água em recipientes domésticos, por longos períodos, quando não existe uma caixa d'água no local, pode comprometer a qualidade da mesma, pois existe a possibilidade de ocorrerem mudanças na concentração de cloro, que é um importante agente químico utilizado para descontaminação (SOBSEY; HANDZEL; VENCZEL, 2003).

A utilização do cloro como agente químico consiste em uma satisfatória proteção residual da água, mesmo diante de variadas estratégias de armazenamento doméstico (SMITH; KOMOS, 2009), ou seja, a adição do cloro na água revela-se eficiente para a descontaminação da água armazenada em reservatórios domésticos (caixas d'água), ou daquela que permanece em recipientes utilizados dentro dos domicílios, muito encontrados em áreas sem infra-estrutura de rede de abastecimento público. 
A temperatura da água e pH podem sofrer alteração dependendo do tempo de armazenamento e da condição física do reservatório, dada a exposição ambiental e/ou tipo de material utilizado na fabricação do reservatório. A temperatura influencia nas características comportamentais dos organismos, na solubilidade de gases e sais presentes na água e o pH tem um efeito indireto sobre a precipitação de elementos tóxicos, como metais, além de interferir na reatividade do cloro, a qual diminui com o aumento do $\mathrm{pH}$ (MEYER, 1994; PARASHAR et al., 2008).

Segundo D'Aguila et al. 2000, exceto poucas e incompletas iniciativas municipais e estaduais, não existe legislação em vigor que estabeleça as normas de uso, manutenção e limpeza dos reservatórios de água, definindo com clareza as competências e responsabilidades.

Vale ressaltar, que outra complicação advinda da falta de manutenção e vedação inadequada das caixas d'água é a crescente preocupação com a proliferação do mosquito Aedes aegypti nesses reservatórios.

No município de Ribeirão Preto, somente no primeiro bimestre de 2011, a Vigilância Epidemiológica registrou 1.465 casos da doença. A Prefeitura, por meio da Secretaria Municipal de Saúde, vem tentando reduzir os casos da doença para evitar uma situação semelhante ao ocorrido no ano anterior, quando o município apresentou 29.949 casos de dengue em 2010 (FURTADO, 2011). 


\section{CONCLUSÕES}


A realização desta investigação possibilitou atingir os objetivos propostos inicialmente, sendo possível apontar as seguintes conclusões:

- A população tem conhecimento sobre a importância da limpeza do reservatório domiciliar de água, porém não a realiza no período recomendado alegando esquecimento ou por considerar que o acesso ao reservatório é dificultado devido à localização do mesmo no domicílio.

- A água consumida no município de Ribeirão Preto-SP mantém uma qualidade satisfatória no que se relaciona às condições microbiológicas, mesmo após o armazenamento em reservatórios domiciliares e de UBS, apropriados a este fim.

- A quantificação de bactérias do grupo Coliformes e Escherichia coli apresentou NMP < 1,8 em todas as amostras de água dos reservatórios domiciliares e UBSs incluídas na investigação.

- Não foram detectados os parasitas: Ancylostoma sp.; Ascaris sp.; Entamoeba histolytica; Entamoeba coli; Hymenolepis sp.; Strongyloides stercoralis nas amostras de água domiciliares e das UBSs analisadas neste estudo.

- As concentrações dos metais As, Be, Ca, Co, Cr, Cu, Fe, Hg, Mn, $\mathrm{Ni}, \mathrm{Pb}, \mathrm{Sn}, \mathrm{TI}, \mathrm{V}$ e $\mathrm{Zn}$ nas amostras de água domiciliares e das UBSs, apresentaram concentrações de acordo com os níveis recomendados pela Portaria 518/2004 e Organização Mundial da Saúde.

- Os parâmetros físico-químicos (pH, cloro e temperatura) apresentaram valores de acordo com os recomendados pela Portaria 518/2004.

Considerando a importância do monitoramento da qualidade da água destinada ao consumo humano, do manancial ao ponto de consumo, concluímos que a água consumida no município de Ribeirão Preto-SP 
atende às recomendações da Portaria 518/2004 e após o correto armazenamento domiciliar e predial apresenta boas condições sanitárias, garantindo um consumo seguro à população. 


\section{CONSIDERAÇÕES FINAIS}


Acredita-se que a qualidade da água procedente do Aquífero Guarani, aliada ao monitoramento realizado pela empresa municipal responsável pelo abastecimento público da água, estejam colaborando para a manutenção das adequadas condições microbiológicas e físico-químicas da água consumida nos domicílios de Ribeirão Preto-SP. No entanto, devemos ressaltar a importância das ações da população para o controle da qualidade domiciliar, realizando periodicamente a limpeza dos reservatórios, seguindo as recomendações dos órgãos competentes.

O reservatório domiciliar, quando é bem instalado e são mantidas as condições de higiene e limpeza, pode minimizar uma possível contaminação da água dentro do domicílio, uma vez que não ocorre um manejo que possibilite a contaminação através da introdução de objetos e das mãos, no recipiente.

O uso rotineiro da água do reservatório possibilita uma troca do volume armazenado, diminuindo o risco de contaminação por metais, os quais podem apresentar variações em suas concentrações diante do tempo de estagnação da água dentro do reservatório, sendo importante a utilização diária desta água nas atividades de higiene pessoal e limpeza doméstica.

Apesar dos resultados não revelarem contaminação nas amostras estudadas, a população necessita ser periodicamente informada sobre a importância da limpeza do reservatório, fazendo uso de objetos e produtos adequados para a remoção do biofilme ali formado, assegurando assim a manutenção da boa qualidade da água a ser consumida e utilizada diariamente em cômodos como os banheiros e cozinhas.

O abastecimento de água de qualidade em quantidade suficiente é fundamental para a prevenção de uma série de doenças de veiculação hídrica. No entanto, este processo só é eficaz quando existe um acompanhamento da qualidade da água de modo a evitar possíveis riscos para a saúde dos consumidores. Essa vigilância existe e é executada nas Estações de Tratamento da Água até o momento em que chega aos 
domicílios (no medidor de água/ hidrômetro ou cavalete), a partir deste ponto, porém, a qualidade da água é de responsabilidade dos moradores.

A boa qualidade da água estudada pode estar relacionada ao fato do município de Ribeirão Preto - SP ser abastecido com água captada através de poços subterrâneos, recebendo apenas a adição de cloro e flúor, procedimento recomendado pela Portaria 518/2004 (BRASIL, 2004), portanto, não sofrendo alterações em suas características originais.

Além disso, existe o monitoramento diário da qualidade da água de abastecimento realizado pela empresa municipal responsável pelo serviço, a qual segue um protocolo de realização de coletas diárias para 0 monitoramento das características físico-químicas e bacteriológicas da água a ser consumida no município.

Considera-se o monitoramento da qualidade da água destinada ao consumo humano uma ação imprescindível no âmbito da saúde pública.

A ampliação do conhecimento e das ações direcionadas ao monitoramento da qualidade da água permite a elaboração de planos e programas objetivando o acesso à água, diante de um quadro de escassez previsto para as próximas décadas.

Existe atualmente uma preocupação crescente com 0 desenvolvimento de ações individuais direcionadas à saúde humana e prevenção de doenças relacionadas ao acesso e utilização da água. Portanto, programas de educação para a saúde são necessários na tentativa de orientar a participação da comunidade em atividades relacionadas à saúde ambiental, visando promover melhorias na qualidade de vida da população.

Diante do contexto apresentado, considera-se relevante a continuidade de investigações que possam auxiliar a tomada de decisões, do poder público e da comunidade, relacionadas ao planejamento de ações integradas de saúde ambiental, visando a avaliação da qualidade da água destinada ao consumo humano. 
8. Atividades científico-acadêmicas 
- Trabalhos publicados em periódicos internacionais.

K.A.A. TONANI • F.C. JULIÃO • T.M.B. TREVILATO • A.M.M. TAKAYANAGUI • A. BOCIO • J.L. DOMINGO • S.I. SEGURA-MUÑOZ. Behavior of Metals, Pathogen Parasites and Indicator Bacteria in Sewage Effluents during Biological Treatment by Activated Sludge. Biological Trace Element Research (no prelo 10 nov 2010).

NIKAIDO, M.; Tonani, K.A.A.; JULIÃO, F. C.; TREVILATO, T. M. B.; TAKAYANAGUI, A. M. M.; SANCHES, S. M.; Domingo, J.L; SEGURAMUÑOZ, S.I. Analysis of Bacteria, Parasites, and Heavy Metals in Lettuce (Lactuca sativa) and Rocket Salad (Eruca sativa L.) Irrigated with Treated Effluent from a Biological Wastewater Treatment Plant. Biological Trace Element Research, v. 130, p. 87-95, 2009.

FERREIRA, P.C.; TONANI, K.A.A; JULIÃO, F. C.; CUPO, P.; DOMINGO, J.L; SEGURA-MUÑOZ, S.I. Aluminum Concentrations in Water of Elderly Peoples's Houses and Retirement Homes and Its Relation with Elderly Health. Bulletin of Environmental Contamination and Toxicology, v. 83, p. 15, 2009.

- Resumos publicados em Anais e Programas de eventos / Trabalhos apresentados em eventos científicos nacionais e internacionais.

JULIÃO, F. C.; TONANI, K.A.A.; CELERE, M. S.; RAGAZZI, M. F.; ALVES, R. I. S.; SEGURA-MUÑOZ, S.I. Análise microbiológica e físico-química de amostras de água de reservatórios domiciliares do município de Ribeirão Preto-SP, Brasil.. In: XX Congresso Latinoamericano de Microbiología y el IX Encuentro Nacional de Microbiólogos, 2010, Montevideo. ALAM Libro de Resúmenes. Montevideo : Sociedad Uruguaya de Microbiología SUM, 2010. v. 1. p. 85-85.

JULIÃO, F. C.; TONANI, K.A.A.; CELERE, M. S.; RAGAZZI, M. F.; CARDOSO, O. O.; SEGURA-MUÑOZ, S.I. Análise microbiológica e físicoquímica de amostras de água de reservatórios de unidades básicas de saúde (UBS) do município de Ribeirão Preto-SP, Brasil.. In: XX Congresso Latinoamericano de Microbiología y el IX Encuentro Nacional de Microbiólogos, 2010, Montevideo. ALAM Libro de Resúmenes. Montevideo : Sociedad Uruguaya de Microbiología SUM, 2010. v. 1. p. 85-85.

RAGAZZI, M. F.; NIKAIDO, M.; TONANI, K.A.A ; JULIÃO, F. C. ; CARDOSO, O. O. ; SEGURA-MUÑOZ, S.I. . Relações entre a utilização de água de reuso para irrigação e a presença de Cryptosporidium spp. e Giardia spp. em hortaliças. In: XX Congresso Latinoamericano de Microbiología y el IX Encuentro Nacional de Microbiólogos, 2010, Montevideo. ALAM Libro de Resúmenes. Montevideo: Sociedad Uruguaya de Microbiología, 2010. v. 1. p. 91-91. 
TONANI, K.A.A ; JULIÃO, F. C. ; RAGAZZI, M. F. ; HACHICH, E. M.; CARDOSO, O. O.; PADULA, J. A.; SEGURA-MUÑOZ, S.I. . A importância da análise de Cryptosporidium spp. e Giardia spp. na água: desafios no contexto da vigilãncia ambiental em saúde.. In: $X X$ Congresso Latinoamericano de Microbiología y el IX Encuentro Nacional de Microbiólogos, 2010, Montevideo. ALAM Libro de Resúmenes. Montevideo : Sociedad Uruguaya de Microbiología, 2010. v. 1. p. 205-205.

JULIÃO, F. C.; TONANI, K.A.A ; CARDOSO, O. O. ; NADAL, M ; SEGURAMUÑOZ, S.I. . Análise de metais pesados em água de reservatórios domiciliares do município de Ribeirão Preto/SP. In: XI Congresso Brasileiro de Ecotoxicologia - ECOTOX, 2010, Bombinhas. Ecotox 2010 - XI Congresso Brasileiro de Ecotoxicologia. São Paulo: Tec Art Editora Ltda, 2010. v. 1. p. 257-257.

ALVES, R. I. S; CARDOSO, O. O. ; TONANI, K.A.A ; JULIÃO, F. C. ; TREVILATO, T. M. B. ; SEGURA-MUÑOZ, S.I. . Avaliação de parâmetros limnológicos, parasitas, bactérias e metais pesados em água superficial no Córrego Ribeirão Preto, Ribeirão Preto/SP. In: XI Congresso Brasileiro de Ecotoxicologia - ECOTOX, 2010, Bombinhas. ECOTOX 2010 - XI Congresso Brasileiro de Ecotoxicologia. São Paulo: Tec Art Editora Ltda, 2010. v. 1. p. 447-447.

JULIÃO, F. C.; CARDOSO, O. O. ; TONANI, K.A.A ; ALVES, R. I. ; NADAL, $\mathrm{M}$; SEGURA-MUÑOZ, S.I. . Physical, chemical and microbiological quality of water storaged in domestic reservoirs. In: International Congress of Environmental Research, 2010, Réduit. ICER 10 - Proceedings Editorial Board, 2010. v. 1. p. 149-149.

ALVES, R. I. S.; CARDOSO, O. O. ; TONANI, K.A.A ; JULIÃO, F. C. ; TREVILATO, T. M. B. ; SEGURA-MUÑOZ, S.I. . Evaluation of limnological parameters, parasites, bacteria and heavy metals in superficial water of Ribeirão Preto Stream, Ribeirão Preto-SP, Brazil. In: International Congress of Environmental Research, 2010, Réduit. ICER 10 - Proceedings Editorial Board, 2010. v. 1. p. 100-100.

CARDOSO, O. O. ; JULIÃO, F. C.; TONANI, K.A.A ; ALVES, R. I. S. BAENA, A. R.; DIEZ, I. G.; CALIA, R. C.; Domingo, J.L; TREVILATO, T. M. B.; SEGURA-MUÑOZ, S.I. . Matern milk, water and soil: relatiuonship between heavy metals in those environmental matrices. In: International Congress of Environmental Research, 2010, Réduit. ICER 10 - Proceedings Editorial Boards, 2010. v. 1. p. 347-348.

JULIÃO, F.C.; TONANI, K.A.A.; SEGURA-MUÑOZ. Análise parasitológica de amostras de água de reservatórios de Unidades Básicas de Saúde do município de Ribeirão Preto-SP. In: XXI Congresso Brasileiro de 
Parasitologia e II Encontro de Parasitologia do Mercosul, 2009, Foz do Iguaçu. Revista Patologia Tropical, 2009. v. 38, supl 2, p. 225.

JULIÃO, F.C.; TONANI, K.A.A.; SEGURA-MUÑOZ, S.I.; TAKAYANAGUI, A.M.M. Condição parasitológica de amostras de fezes de moradores de uma favela do município de Ribeirão Preto- SP. In: XXI Congresso Brasileiro de Parasitologia e II Encontro de Parasitologia do Mercosul, 2009, Foz do Iguaçu. Revista Patologia Tropical, 2009. v. 38, supl 2, p. 244.

TONANI, K.A.A., JULIÃO, F.C.; NIKAIDO, M.; TREVILATO, T.M.B.; TAKAYANAGUI, A.M.M.; SEGURA-MUÑOZ, S.I. Remoção de metais pesados, parasitas e bactérias pelo sistema lodos ativados da Estação de Tratamento de Esgoto de Ribeirão Preto-SP. In: XXI Congresso Brasileiro de Parasitologia e II Encontro de Parasitologia do Mercosul, 2009, Foz do Iguaçu. Revista Patologia Tropical, 2009. v. 38, supl 2, p. 222.

NIKAIDO, M.; TONANI, K.A.A.; JULIÃO, F.C.; TREVILATO, T.B.; TAKAYANAGUI, A.M.M.; SANCHES, S.; DOMINGO, J.L.; SEGURAMUÑOZ, S.I. Uso de águas residuárias tratadas na cultura de hortaliças: avaliação de bactérias, enteroparasitas e metais pesados. In: XXI Congresso Brasileiro de Parasitologia e II Encontro de Parasitologia do Mercosul, 2009, Foz do Iguaçu. Revista Patologia Tropical, 2009. v. 38, supl 2, p. 1199.

ALVES, R.I.S.; CARDOSO, O.O.; TONANI, K.A.A.; JULIÃO, F.C.; SEGURAMUÑOZ, S.I. Avaliação de parasitas e bactérias em água superficial do Córrego Ribeirão Preto-SP, como indicadores de fontes difusas e pontuais de poulição. In: XXI Congresso Brasileiro de Parasitologia e II Encontro de Parasitologia do Mercosul, 2009, Foz do Iguaçu. Revista Patologia Tropical, 2009. v. 38, supl 2, p. 1076.

CARDOSO, O.O.; TONANI, K.A.A.; JULIÃO, F.C.; ALVES, R.I.S.; BÓCIO, A., DOMINGO, J.L.; SEGURA-MUÑOZ, S.I. Avaliação da concentração de chumbo na água ingerida e no leite de mães do município de Conceição das Alagoas - MG. In: $1^{\circ}$ Simpósio sobre Chumbo e a Saúde Humana. Ribeirão Preto, 2009. Apresentação pôster.

TONANI, K.A.A.; JULIÃO, F.C.; TREVILATO, T.M.B.; TAKAYANAGUI, A.M.M.; SEGURA-MUÑOZ, S.I. Cryptosporidium ssp. oocysts, Giardia ssp. cysts and vírus in sewage and sewage sludge: an approach for public health. In: 12th World Congress On Public Health. Istambul, 2009. Proceedings.

JULIÃO, F.C.; TONANI, K.A.A.; CARDOSO, O.O.; SEGURA-MUNÕZ, S.I. Percepção da população sobre a importância da manutenção e limpeza do reservatório domiciliar de água no contexto da saúde pública. In: II Congresso de Investigação em Enfermagem Ibero-Americano e de Países de Língua Oficial Portuguesa. Revista Científica da Unidade de Investigação em Ciências da Saúde, 2009, p.369. 
ALVES, R.I.S.; CARDOSO, O.O.; TONANI, K.A.A.; JULIÃO, F.C.; TREVILATTO, T.M.B.; SEGURA-MUÑOZ, S.I. Evaluación de parametros físico-quimicos, metales pesados, parasitos y bactérias em agua superficial del rio ribeirão preto, Ribeirão Preto - SP, Brasil. In: XIII Congreso Bolivariano - XVII Congreso Nacional de Ingenieria Sanitaria y Ambiental, 2009, Lima-Peru. CD Room - apresentação V.

SEGURA-MUÑOZ, S.I.; NIKAIDO, M.; JULIÃO, F.C.; CUPO, P.; TAKAYANAGUI, A.M.M. Intoxicações domésticas por agentes químicos na infância: estudo retrospectivo de 2000 a 2005. Congresso Interdisciplinar Saúde, Educação e Ambiente. Ribeirão Preto, jun 2008. In: Anais do Congresso Interdisciplinar Saúde, Educação e Ambiente.

JULIÃO, F.C.; TAKAYANAGUI, A.M.M.; SEGURA-MUÑOZ, S.I. Água e Saúde em uma favela do município de Ribeirão Preto-SP. II Congresso Aqüífero Guarani. Ribeirão Preto, nov 2008. In: Anais do II Congresso Aqüífero Guarani (http://www.aquiferoguaranicongresso.com.br/trabalhosapresentados.pdf).

- Atividades acadêmicas.

- Monitoria. Curso de curta duração /Especialização em Infecção Hospitalar. Docente responsável: Profa Dra Susana Inés Segura Muñoz. Local: Escola de Enfermagem de Ribeirão Preto/ Universidade de São Paulo. Aulas: Escabiose: Dermatozoonose parasitária de importância clínica / Esquistossomose: parasitose de veiculação hídrica de importância clínica. Data 2010

- Representante Discente. Parecer no Projeto de Doutorado da aluna Eliana Leão do Prado, para realização de parte do doutorado na Universidade Nova de Lisboa, Portugal em 2010.

- Estágio. Programa de Aperfeiçoamento de Ensino (PAE). Disciplina: Paradigmas Didáticos-Pedagógicos e Estratégias Alternativas no Processo Ensino Aprendizagem. Período: $2^{\circ}$ semestre 2008. Local: Escola de Enfermagem de Ribeirão Preto da Universidade de São Paulo.

- Debatedora. $16^{\circ}$ Simpósio Internacional de Iniciação Científica da USP (SIICUSP). Área Biológicas. Local: Centro de Convenções de Ribeirão Preto - Debatedora - Data: 04 e 05 de novembro de 2008.

- Ouvinte. "Seminário Internacional - Desafios da Saúde Pública (presente, passado e futuro)" - período: 6 e 7 de abril de 2008. Realização: Faculdade de Saúde Pública (FSP/USP). São Paulo/SP.

- Monitor. "V Seminário de Saúde Ambiental: ambiente e desenvolvimento humano" período: 12 a 15 de junho de 2008. Realização: Interclínicas 
Ribeiro do Valle / Escola de Enfermagem de Ribeirão Preto da Universidade de São Paulo (EERP/USP). Ribeirão Preto/SP.

-Palestras Ministradas.

- Educação em Saúde: a qualidade da água no contexto da saúde pública. Curso de Especialização em Educação em Saúde. Local: UNESP Araraquara. Data 16 de julho de 2009.

- O Desafio do Biólogo na pesquisa Ambiental. Comemoração da Semana do Biólogo. Local: UNIESP / Taquaritinga. Data: 01 de setembro de 2010.

\section{- Organização de eventos acadêmicos}

- Seminário Internacional - Contaminantes Ambientais: exposição através dos alimentos e avaliação de riscos para a saúde. Comissão organizadora. Local: Escola de Enfermagem de Ribeirão Preto/Universidade de São Paulo. Data: 04/09/2009.

- Congresso Interdisciplinar: Saúde, Educação e Ambiente. Comissão Organizadora. Local: Centro de Convenções de Ribeirão Preto. Data:

- Matérias de jornais e revistas não científicas; material artístico e didático.

JULIÃO, F.C.; SEGURA-MUÑOZ, S.I. Reciclando o Lixo. Revista Dicas Mulher. Número 107, Março de 2011. Editora: A2B Comunicação Visual LTDA.

JULIÃO, F.C.; SEGURA-MUÑOZ, S.I. Leite materno: alimento e amor num gesto de carinho. Revista Dicas Mulher. Número 102, Outubro de 2010. Editora: A2B Comunicação Visual LTDA.

\section{- Cursos e Visitas Técnicas.}

- Visita técnica realizada ao Centro de Investigação e Estudos em Saúde Pública, da Escola Nacional de Saúde Pública da Universidade Nova de Lisboa. Período: 16 de novembro de 2009 - Lisboa, Portugal.

- Visita técnica ao Instituto Nacional de Saúde Dr. Ricardo Jorge. Período: 17 de novembro de 2009 - Lisboa, Portugal.

- Visita técnica ao Laboratório de Toxicologia e Saúde Ambiental da Faculdade de Ciências Médicas da Universidade "Rovira i Virgili". Período: 26 e 27 de novembro de 2009 - Reus, Espanha.

- Curso "Detecção Laboratorial dos Protozoários Patogênicos de Veiculação Hídrica: perspectivas atuais e novos horizontes na parasitologia clínica e ambiental". Período; 26 e 27 de outubro de 2009. Foz do Iguaçu. 
- II Jornada de Microbiologia Clínica. Período: 12 de setembro de 2009. Ribeirão Preto.

- Curso "Análises Microbiológicas de Amostras Ambientais". Período: 03 a 07 de agosto de 2009. CETESB, São Paulo.

- Curso: Coleta e Preservação de Amostras de Água e Esgoto. Período: 10 a 12 de novembro de 2008. Realização: Associação Brasileira de Engenharia Sanitária e Ambiental (ABES) - sub-regional Franca/SP. 


\section{REFERÊNCIAS}


ABRAHAMS, N.; HUBBELL, B.; JORDAN, J. Joint production and averting expenditure measures of willingness to pay: do water expenditures really measure avoidance costs? American Journal of Agricultural Economics, Milwaukee, v.82, p. 427-437, 2000.

AMERICAN PUBLIC HEALTH ASSOCIATION. Standard methods for the examination for water and wastewater. $21^{\text {th }}$, Washington, DC: APHA, AWWA, WEF, 2005, $1368 \mathrm{p}$.

ATSDR, Cadmium toxicity - Case Studies in Environmental Medicine. Agency for Toxic Substances and Disease Registry, U.S. Department of Health and Human Services, Atlanta, GA. 2008.

BARCELLOS, C.; QUITÉRIO, L.A.D. Vigilância ambiental em saúde e sua implementação no Sistema Único de Saúde. Revista de Saúde Pública, São Paulo, v.40, n.1, p. 170-177, 2006.

BORAH, K.K.; BHUYAN, B.; SARMA, H.P. Heavy metal contamination of groundwater in the tea garden - belt of Darrang District, Assam, India. EJournal of Chemistry, Adirampattinam, v.6, p. 501-507, 2009.

BOTELHO, M.H.C.; RIBEIRO JR, G.A. Instalações hidráulicas prediais. 2.ed. São Paulo; Editora Blücher, 2007. 360p.

BRASIL. Ministério da Saúde. Programa Nacional em Saúde Ambiental Relacionada à Qualidade da Água para Consumo Humano. Brasília, 2003. $43 \mathrm{p}$.

Portaria MS $\mathrm{n}^{\circ} 518$ de 25 de março de 2004. Estabelece os procedimentos e responsabilidades relativos ao controle e vigilância da qualidade da água para consumo humano e seu padrão de potabilidade, e dá outras providências. Diário Oficial da União, Brasília, DF, 26 mar. 2004.

. Ministério da saúde. A,B,C,D,E de hepatites para comunicadores. Brasília, DF, Ministério da Saúde, 2005. 24 p

Fundação Nacional de Saúde. Manual de saneamento. 3 ed.,2006, $408 \mathrm{p}$. 
Ministério da Saúde. O SUS de A a Z: garantindo saúde nos municípios. Brasília, 2009. 481 p.

BRICK, T. et al. Water contamination in urban south India: household storage practices and their implications for water safety and enteric infections. International Journal of Hygiene and Environmental Health, New York, v.207, n. 5, p. 473-480, 2004.

CAMPOS, I.M. Esquema de funcionamento e dimensionamento da instalação de água fria em residências. Disponível em: http://www.forumdaconstrucao.com.br/conteudo.php?a=27\&Cod=118. Acesso em: 08 nov 2010.

CASTANIA, J. Qualidade da água utilizada para consumo em escolas públicas municipais de ensino infantil em Ribeirão Preto-SP. 2009. $146 f$. Dissertação (Mestrado em Enfermagem em Saúde Pública) - Escola de Enfermagem de Ribeirão Preto, Universidade de São Paulo, Ribeirão Preto, 2009.

CASTRO, H.; GIANNASI, F.; NOVELLO, C. A luta pelo banimento do amianto nas Américas: uma questão de saúde pública. Ciência e Saúde Coletiva, Rio de Janeiro, v.8, n.4, p. 903-911, 2003.

CHAIDEZ, C.; SOTO, M.; MARTINEZ, C.; KESWICK, B. Drinking water microbiological survey of the Northwestern State of Sinaloa, México. Journal of Water and Health, London, v.6, n.1, p. 125-129, 2008.

CHAKRABARTY, S.; SARMA, H.P. Heavy metal contamination of drinking water in Kamrup district, Assam, India. Environmental Monitoring and Assessment, New York. DOI: 10.1007/s10661-010-1750-7.

CIIAGRO. 2010. Monitoramento do clima. Disponível em http://ciiagro.sp.gov.br/ciiagroonline/Listagens/MonClim/LMCClimLocal.asp.

Acesso em: 5 nov 2010.

CLASEN, T.F.; BASTABLE, A. Faecal contamination of drinking water during collection and household storage: the need to extend protection to the point of use. Journal of Water and Health, London, v.1, n.3, p.109-115, 2003. 
COMPANHIA AMBIENTAL DO ESTADO DE SÃO PAULO. Guia de coleta e preservação de amostras de água. São Paulo: CETESB, 1998, 135 p.

Análises Microbiológicas de Amostras Ambientais. São Paulo: CETESB, 134 p., 2009.

CONCEIÇÃO, F.T.; CUNHA, R.; SARDINHA, D.S.; SOUZA, A.D.G.; SINELLI, O. Hidrogeoquímica do Aqǘfero Guarani na área urbana de Ribeirão Preto (SP). Geociências, São Paulo, v. 28, n. 1, p. 65-77, 2009.

CORRÊA, L.M.L. Saneantes domissanitários e saúde: um estudo sobre a exposição de empregadas domésticas. 2005. 94f. Dissertação (Mestrado em Saúde Coletiva) - Universidade Federal do Rio de Janeiro, Rio de Janeiro, 2005.

CROSSGROVE, J.; ZHENG, W. Manganese toxicity upon overexposure. NMR in Biomedicine, Malden, v.17, 2004, p. 544-553.

D'ÁGUILA, P.S. et al. Avaliação da qualidade da água para abastecimento público do município de Nova Iguaçu. Cadernos de Saúde Pública, Rio de Janeiro, v. 16, n. 3, p. 791-798, 2000.

DANIEL, L.A. (organizador). Processos de desinfecção e desinfetantes alternativos na produção de água potável. São Carlos (SP): PROSAB/Finep; 2001.

$\mathrm{DARCI} B O M, J$. A influência da qualidade da água, de reservatórios domiciliares, na qualidade de vida da população de Umuarama - Pr. 2002. 214f. Dissertação (Mestrado em Gestão de Qualidade Ambiental), Universidade Federal de Santa Catarina, Florianópolis, 2002.

DAS, B. et al. Groundwater arsenic contamination, its health effects and approach for mitigation in West Bengal, India and Bangladesh. Water Quality Exposure and Health, Dordrecht, v.1, p.5-21, 2009.

DIAS, E.C.; RIGOTTO, R.M.; AUGUSTO, L.G.S.; CANCIO, J.; HOEFEL, M.G.L. Saúde ambiental e saúde do trabalhador na atenção primária à saúde, no SUS: 
oportunidades e desafios. Ciência e Saúde Coletiva,Rio de Janeiro, v. 14, n. 6,, p. 2061-2070, 2009.

DÓREA, J. G.; DONANGELO, C. M. Early (in uterus and infant) exposure to mercury and lead. Clinical Nutrition,New York, v. 25, p.369-376, 2006.

DORIA, M.F. Bottled water versus tap water; understanding consumers preferences. Journal of Water and Health, London, v.4, p. 271-276, 2006.

FREITAS,M.B.; BRILHANTE, O.M.; ALMEIDA, L.M. Importância da análise da água para a saúde pública em duas regiões do Estado do Rio de Janeiro: enfoque para coliformes fecais, nitrato e alumínio. Cadernos de Saúde Pública, Rio de Janeiro, v.17, n.3, p. 651-660, 2001.

FORTLEV. Produtos. Disponível em: http://www.fortlev.ind.br/produtos/caixadagua.html. Acesso em 01 mar 2011.

FORTUNA, C.M. O trabalho de equipe numa unidade básica de saúde produzindo e reproduzindo-se em subjetividade: em busca do desejo, do dever e de singularidades. 1999. 247 f. Dissertação (Mestrado em Enfermagem em Saúde Pública), Universidade de São Paulo, Ribeirão Preto, 1999.

FURTADO, E.G. Saúde registra redução de $75 \%$ nos casos de dengue em Ribeirão Preto, em relação ao ano passado. Disponível em: http://www.ribeiraopreto.sp.gov.br/ccs/snoticias/i33principal.php?id=17411.

Acesso em: 24 fev 2011.

GOHRINGER, S.S. Uso urbano e não potável de efluentes de Estações de Tratamento de Esgoto Sanitário: estudo de caso no município de Campo Largo - PR. 2006. 238 f. Dissertação (Mestrado em Gestão Urbana), Pontifícia Universidade Católica do Paraná, Curitiba, 2006.

GONZÁLEZ, M.M. et al. Detección de poliovirus em águas residuales de Armenia, Colombia. Revista de Salud Publica, Bogotá, n.1, p. 13-23, 2006, Sup.8.

GRABOW, W. Waterborne diseases: update on water quality assessment and control. In: Amaral, L.A; Nader, A. F; Rossi Jr.; O. D.; Ferreira, F. L. A.; Barros, 
L. S.S. Água de consumo humano como fator de risco à saúde em propriedades rurais. Revista de Saúde Pública, São Paulo, v. 37, n. 4, p. 510514, 2003.

HOQUE, A.B. et al. Rural drinking water at supply and household levels: quality and management. International Journal of .Hygiene and .Environmental Health, new York, v. 209, n. 5, p. 451-460, 2006.

INSTITUTO BRASILEIRO DE GEOGRAFIA E eStATÍSTICA. Pesquisa nacional por amostra de domicílio. Disponível em: http://www.ibge.gov.br/home/presidencia/noticias/noticia visualiza.php?id notic $\mathrm{i} a=1455 \&$ id pagina=1. Acesso em 18 set 2009.

Ranking de população por Estado:São Paulo Disponível em: http://www.ibge.gov.br/home/estatistica/populacao/estimativa2009/POP2009 D OU.pdf. Acesso em: 03 dez 2010.

INSTITUTO DE PESQUISA ECONÔMICA APLICADA. Saneamento básico e habitação. Brasília, 2008. 24 p.

JALEEL, M.A.; NOREEN, R.; BASEER, A. Concentration of heavy metals in drinking water of different localities in district east Karachi. Journal of Ayub Medical College, Abbottabad, v.13, n.4, p. 12-15, 2001.

JÄRUP, L. Hazards of heavy metal contamination. British Medical Bulletin, London, v. 68, 2003, p. $167-182$.

JAWAD, I.M et al. Effect of domestic storage tanks on the quality of drinking water. Environmental Monitoring and Assessment, New York, v. 11, p. 7987, 1988.

JENSEN, et al. Domestic transmission routes of pathogens: the problem of inhouse contamination of drinking water during storage in developing countries. Tropical Medicine and International Health,London, v. 7, n.7, p. 604-609, 2002.

JULIAO, F.C. Água para consumo humano e saúde: ainda uma iniqüidade em área periférica do município de Ribeirão Preto-SP. 2003. $76 f$. 
Dissertação (Mestrado em Saúde Pública) - Escola de Enfermagem de Ribeirão Preto, Universidade de São Paulo, São Pauli, 2003.

KORFALI, S.I.; JURDI, M. Provision of safe domestic water for the promotion and protection of public health: a case study of the city of Beirut, Lebanon. Environmental Geochemistry and Health, New York, v. 31, p.283-295, 2009.

LEVINA, A.; LAY, P. A. Chemical Properties and Toxicity of Chromium(III) Nutritional Supplements. Chemical Research in Toxicology, Boston, v. 21, p. 563-571, 2008.

LYTLE, D.A.; SCHOCK, M.R. Impact os stagnation time on metal dissolution from plumbing materials in drinking water. Journal of Water Supply: Research and Technology Aqua, London, v. 49, p. 243-257, 2000.

LUNARDÃO, G.; SOARES, F. M. P. Análise microbiológica da água procedente de reservatórios residenciais do município de Lins - SP. In: SEMINÁRIO DE EXTENSÃO, 8o, 2006, Piracicaba. Anais...Piracicaba: UNIMEP, 2006.

MACEDO, J.A.B. Águas e Águas. São Paulo: Varela, 2000. 505p.

MARET, W.; SANDSTEAD, H.H. Zinc requirements and the risks and benefits of zinc supplementation. Journal of Trace Elements in Medicine and Biology,St Louis, v.20, n.1, p. 3-18., 2006.

MARTONI, A.M. Estudos preliminares para avaliação das condições dos reservatórios domiciliares e da água nas residências unifamiliares de Maringá-PR. 1986, 97f. Dissertação (Mestrado em Engenharia Sanitária), Universidade Federal de Minas Gerais, Belo Horizonte, 1986.

MERKEL, T.H et al. Copper corrosion by products release in long-term stagnation experiments. Water Research, St Louis, v.36, p. 1547-1555, 2002.

MEYER, S.T. O uso de cloro na desinfecção de águas, a formação de trihalometanos e os riscos potenciais à saúde pública. Cadernos de Saúde Pública, Rio de Janeiro, v.1, p. 99-101, 1994. 
MIRANDA, C.A.S.; MONTEIRO, T.C.N. Qualidade da água em sistemas de reservação e distribuição predial na cidade do Rio de Janeiro. Cadernos de. Saúde Pública, Rio de Janeiro, v.5, n.3, p. 284-295, 1989.

MIRLEAN, N. et al. Industrial impact on chemical composition of groundwater: the human consumption aspect (Rio Grande/RS). Revista Química Nova, São Paulo, v.28, n.5, p.778-791, 2005.

MUSA, H.A.; SHEARS, P.; KAFI, S.; ELSABAG, S.K. Water quality and public health in northern Sudan: a study of rural and peri-urban communities. Journal of Applied Microbiology, Malden, v. 87, n. 5, p. 676-682, 1999.

OLIVEIRA, A.P.F.M. Qualidade da água de abastecimento desde o uso e ocupação do solo da bacia do Ribeirão Pitangueiras às torneiras do usuário: estudo de caso do município de Barretos, SP. 2004. $197 \mathrm{f}$. Dissertação (Mestrado em Hidráulica e Saneamento) - Escola de Engenharia de São Carlos, Universidade de São Paulo, São Carlos, 2004.

ORGANIZAÇÃO DAS NAÇÕES UNIDAS (ONU) Coping with water scarcity: challenge of the twenty first century. Roma, 2007. 29p.

The Millennium development goals report 2008. United Nations,New York, 2008. 56p.

ORGANIZAÇÃO DAS NAÇÕES UNIDAS PARA A EDUCAÇÃO, A CIÊNCIA E A CULTURA (UNESCO). Water in a changing world. London, 2009. 349p.

PARASHAR, C. et al. Multivariate analysis of drinking water quality parameters in Bophal, India. Environmental Monitoring and Assessment, New York, v. 140, p. 119-122, 2008.

PECORA, I.L. Doenças de veiculação hídrica. Disponível: http://www.csv.unesp.br/P cbh/downloads/balneabilidade/MaterialAluno.pdf.

Acesso em: 16 ago 2008.

PEREIRA, M.G. Métodos Empregados em Epidemiologia. In: Epidemiologia Teoria e Prática. 8. Ed. Rio de Janeiro: Guanabara Koogan, 2005. Cap. 12, p. 269-288. 
PORTAL APRENDE BRASIL. A esperança de uma revolução ambiental, Salvador, 2007. Disponível em: http://www.aprendebrasil.com.br/reportagens. Acesso em: 07 ago 2007.

PROGRAMA DAS NAÇÕES UNIDAS PARA O DESENVOLVIMENTO. A escassez da água cria nova injustiça: a exclusão hídrica. Disponível em: http://www.pnud.org.br/gerapdf.php?id01=1067. Acesso em: 27 ago 2009.

QUICK, R.E; KIMURA A.;THEVOS, A.; TEMBO, M.; SHAMPUTA, I.; HUTWAGNER, L.; MINTZ, E. Diarrhea prevention through household-level water disinfection and safe storage in Zambia. American. Journal of. Tropical. Medicine and. Hygiene., Deerfield, v. 66, n.5, p. 584-589, 2002.

RANA, S. V. S. Metals and apoptosis: Recent developments. Journal of Trace Elements in Medicine and Biology,New York, v. 22, p. 262-284, 2008.

RAJARATNAM, G., WINDER, C., AN, M. Metals in drinking water from new housing estates in the Sydney area. Environmental Research., New York, v.89, p. 165-170, 2002, Section A.

RIBEIRÃO PRETO. Prefeitura Municipal. Departamento de Água e Esgotos de Ribeirão Preto. De onde vem a água que bebemos? Disponível em: http://www.ribeiraopreto.sp.gov.br/DAERP/PRINCIPAL.HTM Acesso em: 05 mar. 2009.

RIBEIRO, W.C. Aqüífero Guarani: gestão compartilhada e soberania. Estudos Avançados, São Paulo, v. 22, n. 64, p. 227-238, 2008.

RICKARD, A. et al. Bacterial coaggregation: an integral process in the development of multi-species biofilms. Trends in Microbiology, New York, v.11, n. 2, p. 94-100, 2003.

RODWAN Jr., J.G. Challenging circumstances persist: future growth anticipated. Bottled Water Reporters. Disponível em: http://www.bottledwater.org/files/2009BWstats.pdf . Acesso em: 01 mar 2011.

ROYCHOWDHURY, T.; TOKUNAGA, H.; ANDO, M. Survey of arsenic and other heavy metals in food composites and drinking water and estimation of 
dietary intake by the villagers from an arsenic-affected area of West Bengal, India. Science of theTotal Environment, New York, n. 308, p. 15-35, 2003.

RUFENER, S.; MÄUSEZAHL, D.; MOSLER, H.J.; WEINGARTNER, R. Quality of drinking-water at source and point-of-consumption - drinking cup as a high potential recontamination risk: a field study in Bolivia. Journal of Health, Population and Nutrition, Dhaka, v.28, n.1, p. 34-41, 2010.

SALNIKOW, K. ZHITKOVICH, A. Genetic and Epigenetic Mechanisms in Metal Carcinogenesis and Cocarcinogenesis: Nickel, Arsenic, and Chromium. Chemical Research in Toxicology, Boston,. v. 21, p. 28-44., 2008.

SANT'ANA, A.S.; SILVA, S.H.F.L.; FARANI, I.O.; AMARAL, C.H.R.; MACEDO, V.F. Qualidade microbiológica de águas minerais. Ciência e Tecnologia de. Alimentos, Campinas, vol.23, p.190-194, 2003.

SANTOS, A.S. Prevalência de enteroparasitoses na população do município de Maria Helena - Paraná. Revista Ciência e Saúde Coletiva. Online 004/2007. Disponível em: http://www.abrasco.org.br/cienciaesaudecoletiva/artigos/artigo int.php?id artig o=978Acesso em: 25 ago 2009.

SÃO PAULO (Estado). Secretaria do Meio Ambiente. Gestão Ambiental do Aqüífero Guarani. Disponível: http://www.ambiente.sp.gov.br. Acesso em: 13 abr 2007.

SAI SU, G.L. Impacto f drinking water sources in close proximity to the Payatas dumpsite, Philippines. Journal of Public Health, Oxford, v. 15, p. 51-55, 2007.

SCHOCK, M.R.; NEFF, C.H. Trace metal contamination from Brass Fittings. Journal of the American Water Works Association, Denver, v.80, p. 47-56, 1988.

SIBÉRIA, K. Caixas d'água apresentam altos índices de impurezas. Gazeta do Oeste, Mossoró - RN. 16 jul 2006.

SILVA, A.L.O. et al. Dietary intake and health effects of selected toxic elements. Brazilian Journal of. Plant. Physiology, Campinas, v 17, n. 1, p. 79-93, 2005. 
SMITH, E.; KOMOS, S.E. Tap water quality and performance of point-of-use treatment devices in Cairo, Egypt. Water and Environment Journal, Hoboken, v.23, p. 119-127, 2009.

SOBSEY, M.D.; HANDZEL, T.; VENCZEL, L. Chlorination and safe storage of household drinking water in developing countries to reduce waterborne disease. Water Science Technology, London, v 47, n 3, p. 221-228, 2003.

THOMPSON, T.; SOBSEY, M.; BARTRAM, J. Providing clean water, keeping water clean: an integrated approach. International Journal of Environmental Health Research, Oxford, v. 13, S89 - S94,2003.

TREVETT, A.F.; CARTER, R.C.; TYRREL, S.F. The importance of domestic water quality management in the context of faecal-oral disease transmission. Journal of Water and Health, London, v.3, p.259-270, 2005.

VÖLKER, S.; SCHREIBER, C.; KISTEMANN, T. Drinking water quality in household supply infrastructure: a survey of the current situation in Germany. International Journal of Hygiene and Environmental Health, New York, v. 213, p. 204-209, 2010.

WORLD HEALTH ORGANIZATION (WHO) Diretrizes para a água potável de qualidade. WHO: Geneva, 1996. Disponível em: http://www.who.int/water sanitation health/dwq/chemicals/en/ph.pdf. Acesso em 15 jan 2010.

Desinfectants and disinfectant by-product. WHO: Geneva, 2000. Disponível em http://www.who.int/water sanitation health/dwq/S04.pdf. Acesso em 30 mar 2010.

Guidelines for Drinking-water Quality. Genéve:WHO, 2008, 494 p.

WORLD HEALTH ORGANIZATION; UNITED NATIONS CHILDREN'S FUND (WHO/UNICEF). Progress on drinking water and sanitation: special focus on sanitation. Geneva, 2008. 58 p. 2010. 60 p.

Progress on sanitation and drinking-water: 2010 Update. Geneva, 
WRIGHT, J.I.M; GUNDRY, S.; CONROY, R. Household drinking water in developing countries: a systematic review of microbiological contamination between source and point-of-use. Tropical Medicine and International Health, Hoboken, v.9, n.1, p. 106-117, 2004.

ZHENG, N. et al. Population health risk due to dietary intake of heavy metals in the industrial area of Huludao city, China. Science of theTotal Environment, New York, n. 387, p. 96-104, 2007.

ZIADAT, A.H. Impact of storage tanks on drinking water quality in Al-Karak Province - Jordan. Journal of Applied Sciences, New York, v.5, n.4, p. 634638, 2005.

ZIETZ, B.P.; LAB, J.; SUCHENWIRTH, R. Lead in drinking water as a public health challenge. Environmental Health Perspectives, Cary, v. 188, n. 4, p. 154-155, 2010. 


\section{APÊNDICE A}

\section{TERMO DE CONSENTIMENTO LIVRE E ESCLARECIDO}

O $\operatorname{Sr}($ a) está sendo convidado(a) a participar da pesquisa: "Avaliação das condições microbiológicas e físico-químicas da água de reservatório domiciliar e predial: importância e dimensão da qualidade dessa água no contexto da saúde pública” , a qual tem por finalidade analisar amostras de água para verificação da qualidade da mesma.

Ao participar deste estudo o $\operatorname{Sr}($ a) permitirá a obtenção de duas amostras de água do seu domicílio para posterior análise laboratorial. A participação nesta pesquisa não traz complicações legais e a qualquer momento o $\operatorname{Sr}(a)$ poderá pedir esclarecimentos sobre o andamento e os resultados do estudo, os quais serão utilizados somente para fins acadêmicos; sua participação não the trará nenhum benefício direto, no entanto, vale ressaltar que esperamos que este estudo possa colaborar para uma melhor qualidade de vida para a comunidade.

O Sr(a) não terá nenhum tipo de despesa financeira para participar desta pesquisa bem como nada será pago por sua participação a qual poderá ser interrompida em qualquer fase da pesquisa, caso assim decida, bastando para isso entrar em contato com a pesquisadora por meio do endereço e telefones constantes na parte final deste termo.

Após estes esclarecimentos, solicitamos seu consentimento para participação nessa pesquisa. Este termo será assinado em duas cópias, assegurando-Ihe o direito de receber uma delas assinada.

\section{Consentimento Livre e Esclarecido}

Tendo em vista os itens acima apresentados, eu, de forma livre e esclarecida, manifesto meu consentimento em participar da pesquisa.

\section{Nome do Participante da Pesquisa}

Assinatura do Participante da Pesquisa

${ }^{*}$ Assinatura do Pesquisador

Assinatura do Orientador

*Fabiana Cristina Julião - Aluna de Doutorado

e-mail:fabijuliao@usp.br - fone.: (16) 3602-0530

Endereço: Escola de Enfermagem de Ribeirão Preto da Universidade de São Paulo. Laboratório de Ecotoxicologia e Parasitologia Ambiental (LEPA) - Avenida Bandeirantes, 3900 - Campus Universitário, Monte Alegre . Ribeirão Preto / SP - CEP 14040-902. 


\section{APÊNDICE B -- Questionário sobre a limpeza do reservatório domiciliar.}

Caro (a) participante,

Este questionário tem como objetivo obter informações sobre a limpeza da caixa d'água e qualidade da água consumida no seu domicílio. Preserva-se o direito de anonimato e a garantia de que as respostas serão utilizadas apenas para fins acadêmicos. Vale ressaltar que não há nenhum custo e/ou remuneração pela participação.

Questões

1) A sua residência possui reservatório domiciliar (caixa d'água)?

( ) Sim

( ) Não

2) Você tem conhecimento da necessidade de limpeza da caixa d'água?

( ) $\mathrm{Sim}$

( ) Não

3) Sabe qual o período de intervalo correto para a limpeza da caixa d'água?

() 6 meses
1 ano
( ) 2 anos (ou mais)
( ) outro período

4) Quais são os produtos e objetos adequados para a limpeza e manutenção da caixa d'água?

( ) água, sabão em pó, escova de aço

( ) água, detergente, escova de fibra (vegetal ou plástica)

( ) água, desinfetante, vassoura

( ) água, água sanitária, escova de fibra (vegetal ou plástica).

5) Há quanto tempo foi realizada a limpeza da caixa d'água do seu domicílio?

( ) 6 meses

( ) 1 ano

( ) 2 anos (ou mais)

( ) outro período

6) A qualidade da água que chega (da rua) até a sua residência é?

( ) Boa

( ) Ruim

7) Você utiliza a água captada diretamente da torneira (sem a utilização de filtros ou garrafões de água mineral)?

( ) $\operatorname{Sim}$

8) A qualidade da água que vem da caixa d’água da sua residência é?

( ) Boa

( ) Ruim

9) Você utiliza a água da caixa d'água diretamente da torneira?

( ) $\mathrm{Sim}$

( ) Não

10) Em quais cômodos da casa as torneiras recebem água da caixa?

( ) cozinha

( ) banheiro

( ) lavanderia

( ) quintal

( ) área da frente

( ) outros - quais?

(:) Obrigada!

Fabiana Cristina Julião

(16) 3602-0530

e-mail:fabijuliao@yahoo.com.br 


\section{APENDICE C - Concentrações de metais em amostras de água de reservatórios e de pontos da rede de abastecimento público.}

\begin{tabular}{|c|c|c|c|c|c|c|c|}
\hline Origem Espanha & Setor censo & $\mathrm{Cr}$ & $\mathrm{Cu}$ & $\mathrm{Mn}$ & $\mathrm{Ni}$ & $\mathrm{Pb}$ & $\mathrm{Zn}$ \\
\hline $\mathrm{m} 01$ & 361 & 0,0016578 & 0,0098683 & 0,0003493 & 0,0005493 & 0,000341 & 0,0690763 \\
\hline $\mathrm{m} 02$ & 85 & 0,0023518 & 0,0135723 & 0,0002145 & 0,0005 & 0,0006823 & 0,0215023 \\
\hline $\mathrm{m} 03$ & 560 & 0,0025135 & 0,013703 & 0,0003078 & 0,0009066 & 0,0012315 & 0,0510553 \\
\hline $\mathrm{m} 04$ & 561 & 0,0021508 & 0,013223 & 0,0012233 & 0,0018376 & 0,0018695 & 0,0716418 \\
\hline $\mathrm{m} 05$ & 369 & 0,0018565 & 0,010073 & 0,0006515 & 0,0022234 & 0,001135 & 0,0648835 \\
\hline $\mathrm{m} 06$ & 372 & 0,0021203 & 0,0073745 & 0,0003963 & 0,0012461 & 0,0007525 & 0,0491753 \\
\hline $\mathrm{m} 07$ & 562 & 0,0024563 & 0,0041748 & 0,0007145 & 0,0034244 & 0,0042728 & 0,012326 \\
\hline $\mathrm{m} 08$ & 362 & 0,001289 & 0,0047818 & 0,0003183 & 0,0008346 & 0,0003588 & 0,0501783 \\
\hline m09 & 309 & 0,0020193 & 0,041844 & 0,0008858 & 0,0025397 & 0,0068443 & 0,1293048 \\
\hline $\mathrm{m} 10$ & 33 & 0,0017455 & 0,1623863 & 0,0004633 & 0,0019723 & 0,0075308 & 0,08034 \\
\hline $\mathrm{m} 11$ & 399 & 0,0023758 & 0,009019 & 0,0005015 & 0,0015183 & 0,0005853 & 0,055338 \\
\hline $\mathrm{m} 12$ & 81 & 0,0024175 & 0,004485 & 0,00019 & 0,0025156 & 0,0009138 & 0,0126653 \\
\hline $\mathrm{m} 13$ & 37 & 0,0018713 & 0,0126863 & 0,0005725 & 0,0013999 & 0,0004015 & 0,0184013 \\
\hline $\mathrm{m} 14$ & 323 & 0,0030875 & 0,0069388 & 0,0005285 & 0,0015866 & 0,00037 & 0,012013 \\
\hline m15 & 523 & 0,0029955 & 0,0096695 & 0,0003203 & 0,0031948 & 0,0006315 & 0,0210658 \\
\hline $\mathrm{m} 16$ & 294 & 0,002499 & 0,0815005 & 0,012246 & 0,0028024 & 0,0185143 & 0,0601838 \\
\hline $\mathrm{m} 17$ & 631 & 0,0033483 & 0,004725 & 0,000331 & 0,00025 & 0,0002523 & 0,0189013 \\
\hline $\mathrm{m} 18$ & 125 & 0,0019888 & 0,0174223 & 0,0002948 & 0,0005 & 0,0011205 & 0,0269855 \\
\hline $\mathrm{m} 19$ & 608 & 0,001962 & 0,1907745 & 0,0009278 & 0,0020837 & 0,0081445 & 0,0847083 \\
\hline $\mathrm{m} 20$ & 413 & 0,003131 & 0,0139458 & 0,000309 & 0,0019626 & 0,0010608 & 0,0624938 \\
\hline $\mathrm{m} 21$ & 505 & 0,0028438 & 0,0097495 & 0,0001795 & 0,00025 & 0,0003713 & 0,0295458 \\
\hline $\mathrm{m} 22$ & 419 & 0,0059363 & 0,0064023 & 0,0016998 & 0,0039137 & 0,00097 & 0,0546295 \\
\hline $\mathrm{m} 23$ & 499 & 0,0037033 & 0,0118208 & 0,0020628 & 0,0081811 & 0,0022133 & 0,1134853 \\
\hline m24 & 495 & 0,0041393 & 0,2038995 & 0,00025 & 0,0007263 & 0,0007708 & 0,0209258 \\
\hline m25 & 634 & 0,0030103 & 0,0741178 & 0,000367 & 0,0009063 & 0,0011578 & 0,0387593 \\
\hline $\mathrm{m} 26$ & 227 & 0,00025 & 0,0390978 & 0,0075085 & 0,0064489 & 0,002261 & 0,1837283 \\
\hline $\mathrm{m} 27$ & 128 & 0,0018785 & 0,0284188 & 0,0002683 & 0,0020662 & 0,0015308 & 0,0466688 \\
\hline $\mathrm{m} 28$ & 264 & 0,0024348 & 0,006275 & 0,0003455 & 0,0005 & 0,0003708 & 0,0243035 \\
\hline $\mathrm{m} 29$ & 209 & 0,0023588 & 0,0150448 & 0,0001675 & 0,00025 & 0,0008823 & 0,0261388 \\
\hline m30 & 212 & 0,0027458 & 0,0666743 & 0,0005328 & 0,0027802 & 0,0026758 & 0,0719848 \\
\hline m31 & 250 & 0,0024705 & 0,011923 & 0,0011848 & 0,0107991 & 0,0018855 & 0,257879 \\
\hline m32 & 490 & 0,0028218 & 0,0035243 & 0,0002705 & 0,00025 & 0,0006323 & 0,0135475 \\
\hline m33 & 455 & 0,0028328 & 0,061326 & 0,0006463 & 0,0017252 & 0,0040375 & 0,0816835 \\
\hline m34 & 141 & 0,00025 & 0,0020788 & 0,022782 & 0,002076 & 0,0112808 & 0,1885285 \\
\hline m35 & 391 & 0,0027065 & 0,0884355 & 0,0005385 & 0,0166978 & 0,005468 & 0,077307 \\
\hline m36 & 131 & 0,0023515 & 0,0264965 & 0,000309 & 0,0007747 & 0,0009295 & 0,0234408 \\
\hline $\mathrm{m} 37$ & 122 & 0,0020055 & 0,0206265 & 0,0004023 & 0,00025 & 0,0008953 & 0,0345778 \\
\hline m38 & 440 & 0,0045368 & 0,0135453 & 0,0004018 & 0,0005 & 0,001525 & 0,0393858 \\
\hline m39 & 140 & 0,0024495 & 0,0498818 & 0,0004893 & 0,0018736 & 0,0029463 & 0,0462395 \\
\hline
\end{tabular}




\begin{tabular}{|c|c|c|c|c|c|c|c|}
\hline $\mathrm{m} 40$ & 154 & 0,0026588 & 0,0094513 & 0,0003115 & 0,0007969 & 0,0011348 & 0,0443998 \\
\hline $\mathrm{m} 41$ & 317 & 0,0034445 & 0,0288348 & 0,0005645 & 0,0005 & 0,0011905 & 0,028871 \\
\hline $\mathrm{m} 42$ & 332 & 0,0037895 & 0,0101938 & 0,0006418 & 0,0121293 & 0,000823 & 0,0711205 \\
\hline $\mathrm{m} 43$ & 357 & 0,0021208 & 0,0174483 & 0,000227 & 0,00025 & 0,0009278 & 0,121461 \\
\hline $\mathrm{m} 44$ & 605 & 0,0029195 & 0,021571 & 0,000525 & 0,0016762 & 0,0017008 & 0,288336 \\
\hline $\mathrm{m} 45$ & 558 & 0,003217 & 0,0125073 & 0,0004045 & 0,0005 & 0,0009848 & 0,021976 \\
\hline $\mathrm{m} 46$ & 478 & 0,0045328 & 0,0055405 & 0,0005453 & 0,0013546 & 0,0010593 & 0,0147963 \\
\hline $\mathrm{m} 47$ & 559 & 0,0027893 & 0,0035238 & 0,0009365 & 0,0005733 & 0,0004693 & 0,0098658 \\
\hline $\mathrm{m} 48$ & 511 & 0,0028833 & 0,0140845 & 0,000292 & 0,00025 & 0,0006325 & 0,013661 \\
\hline $\mathrm{m} 49$ & 557 & 0,0029918 & 0,0847958 & 0,000643 & 0,00025 & 0,0050195 & 0,029511 \\
\hline m50 & 370 & 0,0026045 & 0,0055845 & 0,0005093 & 0,00025 & 0,0002833 & 0,0083505 \\
\hline m51 & 596 & 0,0023543 & 0,065236 & 0,0007313 & 0,0033247 & 0,0019073 & 0,0702193 \\
\hline m001 & Dutra & 0,0017698 & 0,0076233 & 0,0002225 & 0,0005 & 0,0008053 & 0,029198 \\
\hline m002 & Dutra & 0,0024308 & 0,0066823 & 0,003472 & 0,0007221 & 0,0006533 & 0,027596 \\
\hline m003 & Paiva & 0,00025 & 0,0010545 & 0,000025 & 0,00025 & 0,0002058 & 0,007692 \\
\hline m004 & Paiva & 0,00025 & 0,0044968 & 0,001101 & 0,00025 & 0,0004193 & 0,0211385 \\
\hline m005 & Sampaio & 0,00025 & 0,0095908 & 0,0001503 & 0,0003281 & 0,0006028 & 0,0328443 \\
\hline m006 & Sampaio & 0,00025 & 0,0022295 & 0,0003543 & 0,0002055 & 0,0002853 & 0,0151158 \\
\hline $\mathrm{m} 007$ & Central & 0,0012543 & 0,0054643 & 0,0010415 & 0,000633 & 0,0012255 & 0,0164195 \\
\hline $\mathrm{m} 008$ & Central & 0,001553 & 0,002975 & 0,0002523 & 0,0005668 & 0,0005063 & 0,022607 \\
\hline m009 & Recreio & 0,00025 & 0,0132425 & 0,000025 & 0,0003798 & 0,0005068 & 0,0240523 \\
\hline $\mathrm{m} 010$ & Recreio & 0,00025 & 0,0025498 & 0,0002038 & 0,00025 & 0,0008923 & 0,0224083 \\
\hline m011 & Ipiranga & 0,0053728 & 0,0633828 & 0,0028595 & 0,0140939 & 0,0547863 & 0,749604 \\
\hline $\mathrm{m} 012$ & Ipiranga & 0,0018493 & 0,004866 & 0,0024035 & 0,0003694 & 0,000598 & 0,0670573 \\
\hline $\mathrm{m} 013$ & Tibério & 0,00025 & 0,0093388 & 0,000299 & 0,0003975 & 0,0006685 & 0,016867 \\
\hline $\mathrm{m} 014$ & Tibério & 0,00025 & 0,0022235 & 0,0001733 & 0,0001593 & 0,000517 & 0,0061155 \\
\hline m015 & São José & 0,00025 & 0,0320338 & 0,0014718 & 0,0006561 & 0,0021148 & 0,0623683 \\
\hline $\mathrm{m} 016$ & São José & 0,00025 & 0,0080275 & 0,0020393 & 0,0003058 & 0,0008028 & 0,0200705 \\
\hline m017 & Sta Cruz & 0,00025 & 0,002926 & 0,000272 & 0,0003626 & 0,0013705 & 0,0412773 \\
\hline $\mathrm{m} 018$ & Sta Cruz & 0,00025 & 0,0067495 & 0,0003173 & 0,00025 & 0,0004625 & 0,017958 \\
\hline m019 & Adão & 0,00025 & 0,0090293 & 0,0005025 & 0,0007518 & 0,0025915 & 0,1335105 \\
\hline m020 & Adão & 0,00025 & 0,004199 & 0,000334 & 0,00025 & 0,0002945 & 0,0179198 \\
\hline $\mathrm{m} 021$ & Rib Verde & 0,00025 & 0,0341393 & 0,000025 & 0,0004966 & 0,0021548 & 0,042775 \\
\hline m022 & Rib Verde & 0,00025 & 0,0026958 & 0,0001268 & 0,0001592 & 0,0002965 & 0,0152603 \\
\hline m023 & Valentina & 0,00025 & 0,0178223 & 0,0001943 & 0,0038026 & 0,001076 & 0,0345468 \\
\hline m024 & Valentina & 0,00025 & 0,0051638 & 0,0002815 & 0,0005 & 0,000459 & 0,0282198 \\
\hline m025 & Marinceck & 0,0019713 & 0,0159523 & 0,004907 & 0,00025 & 0,0009 & 0,0190993 \\
\hline m026 & Marinceck & 0,00025 & 0,0035963 & 0,0002635 & 0,00025 & 0,0006455 & 0,02639 \\
\hline $\mathrm{m} 027$ & Simioni & 0,0013085 & 0,1357783 & 0,0027373 & 0,0033448 & 0,0042233 & 0,2727365 \\
\hline m028 & Simioni & 0,00025 & 0,0062863 & 0,0006968 & 0,0006368 & 0,000998 & 0,0273608 \\
\hline m029 & M. Graças & 0,00025 & 0,00852 & 0,000344 & 0,0005 & 0,000758 & 0,041179 \\
\hline m030 & M. Graças & 0,00025 & 0,0037623 & 0,0002488 & 0,0005 & 0,001835 & 0,0277793 \\
\hline $\mathrm{m} 031$ & 637 & 0,0014573 & 0,0456148 & 0,000277 & 0,0011304 & 0,0027323 & 0,0927485 \\
\hline
\end{tabular}




\begin{tabular}{|c|c|c|c|c|c|c|c|}
\hline $\mathrm{m} 032$ & 637 & 0,001952 & 0,0073955 & 0,0013328 & 0,0012139 & 0,0044328 & 0,2130523 \\
\hline $\mathrm{m} 033$ & 612 & 0,00025 & 0,0276733 & 0,0001265 & 0,0003495 & 0,0015123 & 0,0312783 \\
\hline $\mathrm{m} 034$ & 612 & 0,00025 & 0,0217545 & 0,0002185 & 0,0004273 & 0,0017293 & 0,0501593 \\
\hline m035 & 607 & 0,00025 & 0,0151798 & 0,001784 & 0,0014392 & 0,0010513 & 0,0894293 \\
\hline $\mathrm{m} 036$ & 607 & 0,0015635 & 0,0661448 & 0,000618 & 0,0006949 & 0,0045373 & 0,0363415 \\
\hline m037 & 632 & 0,0015333 & 0,0026593 & 0,0003258 & 0,00025 & 0,000389 & 0,0214498 \\
\hline $\mathrm{m} 038$ & 632 & 0,00025 & 0,0057063 & 0,0004455 & 0,000868 & 0,001886 & 0,175713 \\
\hline m039 & 639 & 0,001754 & 0,091567 & 0,000332 & 0,0019684 & 0,0035293 & 0,045885 \\
\hline $\mathrm{m} 040$ & 639 & 0,00025 & 0,0012748 & 0,0001525 & 0,00025 & 0,000313 & 0,0115288 \\
\hline $\mathrm{m} 041$ & 627 & 0,0015155 & 0,015315 & 0,0004548 & 0,0003394 & 0,0005873 & 0,0353173 \\
\hline $\mathrm{m} 042$ & 627 & 0,0015045 & 0,0031138 & 0,000025 & 0,00025 & 0,0003763 & 0,0143698 \\
\hline $\mathrm{m} 043$ & 623 & 0,00025 & 0,0046403 & 0,0004115 & 0,00025 & 0,0004558 & 0,0185125 \\
\hline $\mathrm{m} 044$ & 623 & 0,001779 & 0,0024898 & 0,000025 & 0,00025 & 0,0002743 & 0,0122163 \\
\hline m045 & 479 & 0,00025 & 0,0046618 & 0,0004698 & 0,0005 & 0,0063405 & 0,075546 \\
\hline $\mathrm{m} 046$ & 479 & 0,0021358 & 0,0154938 & 0,0022305 & 0,0005 & 0,0025848 & 0,1626935 \\
\hline $\mathrm{m} 047$ & 642 & 0,001516 & 0,0598888 & 0,0014278 & 0,0014867 & 0,0012858 & 0,1163973 \\
\hline m048 & 642 & 0,00025 & 0,0073613 & 0,000304 & 0,00025 & 0,0002628 & 0,0541253 \\
\hline m049 & 573 & 0,0017243 & 0,0126618 & 0,000542 & 0,0006358 & 0,0007895 & 0,0405785 \\
\hline $\mathrm{m} 050$ & 573 & 0,00025 & 0,0046298 & 0,000025 & 0,0005 & 0,0005528 & 0,031212 \\
\hline $\mathrm{m} 051$ & 641 & 0,001434 & 0,0077165 & 0,0002948 & 0,00025 & 0,0008238 & 0,0489178 \\
\hline m052 & 641 & 0,001629 & 0,0154663 & 0,0003348 & 0,00025 & 0,0008495 & 0,0268088 \\
\hline m053 & 526 & 0,00025 & 0,0022225 & 0,0004673 & 0,0001033 & 0,0002163 & 0,006875 \\
\hline m054 & 526 & 0,00025 & 0,0071935 & 0,0002078 & 0,00025 & 0,0006948 & 0,020545 \\
\hline m055 & 419 & 0,00025 & 0,1316645 & 0,0002853 & 0,0028979 & 0,005556 & 0,0816125 \\
\hline m056 & 419 & 0,00025 & 0,0039183 & 0,0016588 & 0,000217 & 0,0002268 & 0,010977 \\
\hline m057 & 475 & 0,0015163 & 0,0151723 & 0,0003688 & 0,0010812 & 0,0012745 & 0,101116 \\
\hline m058 & 475 & 0,0013325 & 0,0050795 & 0,000158 & 0,00025 & 0,000401 & 0,0609655 \\
\hline m059 & 556 & 0,00025 & 0,0049905 & 0,000025 & 0,00025 & 0,0002708 & 0,0186183 \\
\hline $\mathrm{m} 060$ & 556 & 0,0015855 & 0,0025898 & 0,000439 & 0,00025 & 0,000431 & 0,045817 \\
\hline $\mathrm{m} 061$ & 480 & 0,00025 & 0,005934 & 0,0007088 & 0,0005388 & 0,0003533 & 0,021509 \\
\hline m062 & 480 & 0,00025 & 0,0067338 & 0,000255 & 0,0004209 & 0,0007153 & 0,0173885 \\
\hline $\mathrm{m} 063$ & 475 & 0,0016238 & 0,014662 & 0,000025 & 0,0022793 & 0,000307 & 0,026166 \\
\hline m064 & 475 & 0,001472 & 0,0091678 & 0,0002413 & 0,0004916 & 0,0005188 & 0,0514438 \\
\hline m065 & 7 & 0,0031113 & 0,003063 & 0,0002518 & 0,0003249 & 0,000338 & 0,0089993 \\
\hline m066 & 7 & 0,0013843 & 0,007126 & 0,0002155 & 0,0005 & 0,001588 & 0,0645408 \\
\hline m067 & 6 & 0,00025 & 0,0089435 & 0,0002953 & 0,00025 & 0,0007173 & 0,0412185 \\
\hline m068 & 6 & 0,00025 & 0,0064603 & 0,0002608 & 0,00025 & 0,000595 & 0,027033 \\
\hline m069 & 9 & 0,00025 & 0,0098435 & 0,0003545 & 0,00025 & 0,000466 & 0,0373595 \\
\hline $\mathrm{m} 070$ & 9 & 0,00025 & 0,0060708 & 0,0006473 & 0,00025 & 0,0004373 & 0,0545215 \\
\hline $\mathrm{m} 071$ & 8 & 0,00025 & 0,0074715 & 0,0003328 & 0,0013579 & 0,0019163 & 0,1627358 \\
\hline $\mathrm{m} 072$ & 8 & 0,00025 & 0,0088048 & 0,0009975 & 0,0005179 & 0,0023265 & 0,1265483 \\
\hline $\mathrm{m} 073$ & 18 & 0,00025 & 0,005289 & 0,0003325 & 0,00025 & 0,000409 & 0,0228258 \\
\hline $\mathrm{m} 074$ & 18 & 0,00025 & 0,0033758 & 0,000025 & 0,0001679 & 0,0001958 & 0,0153665 \\
\hline
\end{tabular}




\begin{tabular}{|c|c|c|c|c|c|c|c|}
\hline $\mathrm{m} 075$ & 79 & 0,0016723 & 0,023054 & 0,0002025 & 0,00025 & 0,0009568 & 0,0249298 \\
\hline $\mathrm{m} 076$ & 79 & 0,002566 & 0,0064283 & 0,000323 & 0,0003443 & 0,0006395 & 0,024553 \\
\hline $\mathrm{m} 077$ & 76 & 0,00025 & 0,012442 & 0,000275 & 0,0005179 & 0,0005855 & 0,0131508 \\
\hline $\mathrm{m} 078$ & 76 & 0,0016023 & 0,0070183 & 0,000224 & 0,00025 & 0,000417 & 0,021622 \\
\hline m079 & 368 & 0,00025 & 0,1140063 & 0,0001905 & 0,0008802 & 0,0018788 & 0,1446185 \\
\hline $\mathrm{m} 080$ & 368 & 0,00025 & 0,2055868 & 0,000025 & 0,00025 & 0,0012275 & 0,010852 \\
\hline $\mathrm{m} 081$ & 378 & 0,00025 & 0,007316 & 0,0008273 & 0,0026653 & 0,0005955 & 0,1041955 \\
\hline $\mathrm{m} 082$ & 378 & 0,00025 & 0,0065193 & 0,0001903 & 0,0011095 & 0,0007308 & 0,109444 \\
\hline $\mathrm{m} 083$ & 360 & 0,00025 & 0,0023488 & 0,0012095 & 0,00025 & 0,0027643 & 0,0198605 \\
\hline m084 & 360 & 0,00025 & 0,005697 & 0,000025 & 0,00025 & 0,000204 & 0,0115285 \\
\hline m085 & 376 & 0,003497 & 0,037611 & 0,000309 & 0,0005 & 0,001423 & 0,0226753 \\
\hline m086 & 376 & 0,00025 & 0,0110335 & 0,0002515 & 0,0007219 & 0,0005503 & 0,0236488 \\
\hline $\mathrm{m} 087$ & 379 & 0,00025 & 0,039524 & 0,0007578 & 0,0013501 & 0,001131 & 0,3843478 \\
\hline m088 & 379 & 0,00025 & 0,0082938 & 0,000174 & 0,00025 & 0,0004595 & 0,0230083 \\
\hline m089 & 374 & 0,00025 & 0,0032513 & 0,000159 & 0,00025 & 0,0002323 & 0,0170038 \\
\hline m090 & 374 & 0,00025 & 0,0032975 & 0,0002055 & 0,00025 & 0,0001995 & 0,0183255 \\
\hline m091 & 365 & 0,00025 & 0,0581225 & 0,000595 & 0,0012092 & 0,0016378 & 0,0425885 \\
\hline m092 & 365 & 0,00025 & 0,0060645 & 0,000025 & 0,00025 & 0,0003043 & 0,0167913 \\
\hline m093 & 453 & 0,00025 & 0,431805 & 0,0005233 & 0,0110265 & 0,032157 & 0,5984375 \\
\hline m094 & 453 & 0,00025 & 0,0169985 & 0,0004395 & 0,0005397 & 0,001174 & 0,0150145 \\
\hline m095 & 485 & 0,00025 & 0,079846 & 0,0007858 & 0,0038292 & 0,0054308 & 0,4813483 \\
\hline m096 & 485 & 0,00025 & 0,006105 & 0,0003323 & 0,0002926 & 0,0022683 & 0,0097903 \\
\hline m097 & 479 & 0,00025 & 0,0052173 & 0,0023158 & 0,0006417 & 0,0004738 & 0,0182295 \\
\hline m098 & 479 & 0,00025 & 0,0150253 & 0,0003165 & 0,0005483 & 0,0007348 & 0,0207668 \\
\hline m099 & 481 & 0,00025 & 0,1803385 & 0,0005748 & 0,0025465 & 0,007482 & 0,308717 \\
\hline $\mathrm{m} 100$ & 481 & 0,0012565 & 0,0200063 & 0,0008943 & 0,0006678 & 0,0076498 & 0,081108 \\
\hline m101 & 600 & 0,00025 & 0,0370123 & 0,0003065 & 0,0017817 & 0,0020298 & 0,0710213 \\
\hline m102 & 600 & 0,00025 & 0,0131913 & 0,000453 & 0,00025 & 0,0005163 & 0,0244418 \\
\hline m103 & 604 & 0,00025 & 0,0237015 & 0,0004098 & 0,0006132 & 0,0041275 & 0,0366223 \\
\hline m104 & 604 & 0,001926 & 0,0149493 & 0,0003908 & 0,0006959 & 0,0031658 & 0,0352145 \\
\hline m105 & 614 & 0,00025 & 0,014094 & 0,000025 & 0,00025 & 0,0006918 & 0,0296638 \\
\hline m106 & 614 & 0,00025 & 0,019249 & 0,0002483 & 0,0005 & 0,0011688 & 0,0280895 \\
\hline m107 & 618 & 0,00025 & 0,0833365 & 0,0001633 & 0,0005 & 0,0014385 & 0,0451393 \\
\hline $\mathrm{m} 108$ & 618 & 0,00025 & 0,0034885 & 0,0002435 & 0,0005 & 0,0005375 & 0,01448 \\
\hline m109 & 619 & 0,00025 & 0,0201245 & 0,0006463 & 0,0005726 & 0,0013753 & 0,0241915 \\
\hline $\mathrm{m} 110$ & 619 & 0,00025 & 0,0199643 & 0,0008943 & 0,0009063 & 0,0013545 & 0,0501495 \\
\hline $\mathrm{m} 111$ & 624 & 0,0075085 & 0,3511513 & 0,0024915 & 0,0078925 & 0,0138358 & 0,3421815 \\
\hline $\mathrm{m} 112$ & 624 & 0,001257 & 0,0241715 & 0,001385 & 0,0008493 & 0,0016518 & 0,0264503 \\
\hline $\mathrm{m} 113$ & 114 & 0,00025 & 0,2604498 & 0,0010968 & 0,0190876 & 0,0100803 & 3,1744923 \\
\hline $\mathrm{m} 114$ & 114 & 0,00025 & 0,4446818 & 0,0040425 & 0,0180765 & 0,0294173 & 0,4623505 \\
\hline $\mathrm{m} 115$ & 97 & 0,00025 & 0,0455855 & 0,00083 & 0,0011887 & 0,0014125 & 0,0406583 \\
\hline $\mathrm{m} 116$ & 97 & 0,00025 & 0,6227823 & 0,009617 & 0,0048382 & 0,0369838 & 0,3765793 \\
\hline $\mathrm{m} 117$ & 108 & 0,00025 & 0,0399618 & 0,0009695 & 0,001492 & 0,0033623 & 0,0372633 \\
\hline
\end{tabular}




\begin{tabular}{|c|c|c|c|c|c|c|c|}
\hline $\mathrm{m} 118$ & 108 & 0,00025 & 0,037197 & 0,0021595 & 0,0016732 & 0,0018035 & 0,0282328 \\
\hline $\mathrm{m} 119$ & 94 & 0,00025 & 0,928409 & 0,00073 & 0,0167511 & 0,0286675 & 0,9519105 \\
\hline m120 & 94 & 0,001715 & 0,0456148 & 0,0010668 & 0,0019282 & 0,002764 & 0,0338508 \\
\hline $\mathrm{m} 121$ & 90 & 0,00025 & 0,9783528 & 0,000467 & 0,0023296 & 0,0368428 & 1,415287 \\
\hline $\mathrm{m} 122$ & 90 & 0,00025 & 0,08157 & 0,0006043 & 0,0051731 & 0,0063893 & 0,1416333 \\
\hline m123 & 117 & 0,002076 & 0,0173313 & 0,00016 & 0,0005 & 0,0005923 & 0,1176088 \\
\hline m124 & 117 & 0,0019463 & 0,0374565 & 0,000377 & 0,0005 & 0,0014653 & 0,101746 \\
\hline m125 & 96 & 0,00025 & 0,0313448 & 0,0007835 & 0,0021582 & 0,0021153 & 0,049985 \\
\hline $\mathrm{m} 126$ & 96 & 0,00025 & 0,0575198 & 0,0017478 & 0,002103 & 0,0014505 & 0,0500095 \\
\hline m127 & 650 & 0,0019823 & 0,009797 & 0,0007925 & 0,0005 & 0,0022555 & 0,0493493 \\
\hline m128 & 650 & 0,0014638 & 0,0249035 & 0,0002528 & 0,0009683 & 0,0014785 & 0,0345015 \\
\hline m129 & 651 & 0,0016908 & 0,065994 & 0,0001348 & 0,0010098 & 0,002927 & 0,044817 \\
\hline m130 & 651 & 0,0018733 & 0,0191538 & 0,0005088 & 0,0005 & 0,0016663 & 0,034235 \\
\hline m131 & 652 & 0,0017573 & 0,0142238 & 0,000267 & 0,0005 & 0,0007413 & 0,0253245 \\
\hline m132 & 652 & 0,0018288 & 0,0024713 & 0,0002443 & 0,0005 & 0,0006008 & 0,0157435 \\
\hline $\mathrm{m} 133$ & 653 & 0,0017683 & 0,010163 & 0,0003008 & 0,0005 & 0,0008223 & 0,0831723 \\
\hline m134 & 653 & 0,00025 & 0,0099808 & 0,0004275 & 0,0005 & 0,0031023 & 0,0652648 \\
\hline m135 & 654 & 0,001957 & 0,0085793 & 0,0004255 & 0,0005 & 0,001941 & 0,1315873 \\
\hline $\mathrm{m} 136$ & 654 & 0,0018678 & 0,0801743 & 0,0005185 & 0,0013554 & 0,004834 & 0,1016838 \\
\hline m137 & 655 & 0,002361 & 0,0061463 & 0,0003483 & 0,0005 & 0,0007608 & 0,1326265 \\
\hline $\mathrm{m} 138$ & 655 & 0,0024005 & 0,0203425 & 0,0005215 & 0,001038 & 0,057458 & 0,296921 \\
\hline m139 & 656 & 0,0014973 & 0,0028893 & 0,0002245 & 0,0013937 & 0,0040838 & 0,0295945 \\
\hline $\mathrm{m} 140$ & 656 & 0,0019898 & 0,0028958 & 0,0002628 & 0,0005 & 0,0070855 & 0,12142 \\
\hline $\mathrm{m} 141$ & 657 & 0,0016335 & 0,0064463 & 0,0003788 & 0,0005 & 0,0017395 & 0,0718598 \\
\hline m142 & 657 & 0,0015295 & 0,013708 & 0,0007263 & 0,002849 & 0,0010553 & 0,1559725 \\
\hline $\mathrm{m} 143$ & 452 & 0,00025 & 0,0088945 & 0,0007305 & 0,0005 & 0,0033118 & 0,0588803 \\
\hline $\mathrm{m} 144$ & 452 & 0,00025 & 0,2662058 & 0,000259 & 0,0025738 & 0,0190578 & 0,1329278 \\
\hline $\mathrm{m} 145$ & 454 & 0,00025 & 0,0404078 & 0,0003833 & 0,0023624 & 0,0025158 & 0,1002903 \\
\hline $\mathrm{m} 146$ & 454 & 0,00025 & 0,0696943 & 0,0005875 & 0,0021622 & 0,0020975 & 0,458606 \\
\hline m147 & 456 & 0,00025 & 0,005415 & 0,00049 & 0,0007715 & 0,0009275 & 0,023037 \\
\hline $\mathrm{m} 148$ & 456 & 0,002077 & 0,0124718 & 0,0002625 & 0,0010093 & 0,006563 & 0,0569438 \\
\hline $\mathrm{m} 149$ & 457 & 0,0021488 & 0,0794578 & 0,001892 & 0,0038788 & 0,0033538 & 0,0664528 \\
\hline m150 & 457 & 0,001671 & 0,080431 & 0,0010668 & 0,0030383 & 0,0024693 & 0,083534 \\
\hline m151 & 463 & 0,0031238 & 0,058052 & 0,0009068 & 0,0015336 & 0,0055273 & 0,1115435 \\
\hline m152 & 463 & 0,002733 & 0,0409823 & 0,0004485 & 0,0019968 & 0,0024168 & 0,0571223 \\
\hline m153 & 464 & 0,0020965 & 0,0102175 & 0,0009758 & 0,0013505 & 0,0023715 & 0,0511958 \\
\hline m154 & 464 & 0,00025 & 0,0226528 & 0,0002125 & 0,0003016 & 0,0004315 & 0,033591 \\
\hline m155 & 467 & 0,00025 & 0,0324743 & 0,0020028 & 0,0009384 & 0,001746 & 0,0510455 \\
\hline m156 & 467 & 0,0021748 & 0,0174958 & 0,000628 & 0,0010009 & 0,002734 & 0,1133248 \\
\hline m157 & 87 & 0,00025 & 0,0194453 & 0,0004953 & 0,0014086 & 0,001329 & 0,0428135 \\
\hline m158 & 87 & 0,0013255 & 0,024506 & 0,0005568 & 0,0011771 & 0,0015163 & 0,0380423 \\
\hline m159 & 88 & 0,00025 & 0,0215135 & 0,0008973 & 0,0012532 & 0,0019488 & 0,0406898 \\
\hline $\mathrm{m} 160$ & 88 & 0,00025 & 0,0266245 & 0,0005788 & 0,0014575 & 0,0017603 & 0,0455068 \\
\hline
\end{tabular}




\begin{tabular}{|c|c|c|c|c|c|c|c|}
\hline m161 & 91 & 0,00025 & 0,0354033 & 0,0009933 & 0,0011756 & 0,0016385 & 0,0454273 \\
\hline m162 & 91 & 0,0013655 & 0,0053633 & 0,0004283 & 0,0012707 & 0,0025608 & 0,0291768 \\
\hline $\mathrm{m} 163$ & 92 & 0,00025 & 0,019802 & 0,042798 & 0,0018265 & 0,005974 & 0,040075 \\
\hline m164 & 92 & 0,0032298 & 0,0223428 & 0,0053763 & 0,0011971 & 0,0051203 & 0,039982 \\
\hline m165 & 98 & 0,0018955 & 0,017613 & 0,0005455 & 0,0015905 & 0,0004883 & 0,0370803 \\
\hline $\mathrm{m} 166$ & 98 & 0,00025 & 0,0138883 & 0,0004425 & 0,0005 & 0,0063748 & 0,2764723 \\
\hline m167 & 100 & 0,00025 & 0,009215 & 0,0004263 & 0,0002919 & 0,00115 & 0,032963 \\
\hline m168 & 100 & 0,00025 & 0,0102088 & 0,0003053 & 0,0009377 & 0,0012373 & 0,0335453 \\
\hline m169 & 103 & 0,00025 & 0,0114395 & 0,00043 & 0,0005 & 0,0007275 & 0,065844 \\
\hline $\mathrm{m} 170$ & 103 & 0,00025 & 0,0188105 & 0,0003475 & 0,0012854 & 0,000966 & 0,0362133 \\
\hline $\mathrm{m} 171$ & 243 & 0,0012635 & 0,0201425 & 0,0001275 & 0,0009615 & 0,001405 & 0,0460205 \\
\hline $\mathrm{m} 172$ & 243 & 0,00025 & 0,0054963 & 0,000216 & 0,0004289 & 0,001091 & 0,025234 \\
\hline $\mathrm{m} 173$ & 247 & 0,001564 & 0,0225803 & 0,000497 & 0,0008829 & 0,0020403 & 0,072487 \\
\hline $\mathrm{m} 174$ & 247 & 0,00025 & 0,0077013 & 0,0002718 & 0,0003068 & 0,0009288 & 0,0478538 \\
\hline $\mathrm{m} 175$ & 248 & 0,00025 & 0,0078963 & 0,0002045 & 0,0004255 & 0,000666 & 0,0205768 \\
\hline $\mathrm{m} 176$ & 248 & 0,00025 & 0,2467815 & 0,0002343 & 0,000946 & 0,0061215 & 1,0844325 \\
\hline $\mathrm{m} 177$ & 253 & 0,00025 & 0,139108 & 0,0002678 & 0,0024422 & 0,004323 & 1,634768 \\
\hline $\mathrm{m} 178$ & 253 & 0,00025 & 0,005114 & 0,0003808 & 0,0003953 & 0,0007205 & 0,0212478 \\
\hline m179 & 255 & 0,00025 & 0,0135615 & 0,0001945 & 0,0008005 & 0,0014115 & 0,039956 \\
\hline $\mathrm{m} 180$ & 255 & 0,00025 & 0,0026733 & 0,000248 & 0,0005155 & 0,0010983 & 0,0147983 \\
\hline m181 & 258 & 0,00025 & 0,0231793 & 0,0002825 & 0,000695 & 0,0014853 & 0,0256938 \\
\hline m182 & 258 & 0,00025 & 0,026376 & 0,000673 & 0,0006839 & 0,0012995 & 0,020196 \\
\hline $\mathrm{m} 183$ & 263 & 0,001426 & 0,0098653 & 0,0003368 & 0,00025 & 0,0008358 & 0,016073 \\
\hline m184 & 263 & 0,0018218 & 0,0046653 & 0,000223 & 0,0005 & 0,0010623 & 0,0197828 \\
\hline m185 & 268 & 0,0025845 & 0,010254 & 0,0003795 & 0,0005 & 0,0016813 & 0,0499528 \\
\hline m186 & 268 & 0,00025 & 0,010545 & 0,0004173 & 0,0017107 & 0,0012138 & 0,0462225 \\
\hline m187 & 482 & 0,0022798 & 0,0054048 & 0,00034 & 0,0005 & 0,0015063 & 0,0943343 \\
\hline m188 & 482 & 0,0027273 & 0,0080205 & 0,000392 & 0,0005 & 0,001195 & 0,0789255 \\
\hline m189 & 487 & 0,00025 & 0,0126773 & 0,0001983 & 0,0004414 & 0,0009085 & 0,059443 \\
\hline m190 & 487 & 0,001604 & 0,0489665 & 0,000544 & 0,0097123 & 0,003195 & 0,1494893 \\
\hline m191 & 489 & 0,0022613 & 0,033744 & 0,000327 & 0,0017214 & 0,0020115 & 0,0862783 \\
\hline m192 & 489 & 0,0021713 & 0,0121275 & 0,0003365 & 0,0019851 & 0,0016458 & 0,0817465 \\
\hline m193 & 577 & 0,002418 & 0,0235983 & 0,0002475 & 0,0005 & 0,0015948 & 0,060853 \\
\hline m194 & 577 & 0,0023935 & 0,0164295 & 0,0002245 & 0,0005 & 0,0011168 & 0,0470508 \\
\hline m195 & 588 & 0,0027765 & 0,0099508 & 0,0005253 & 0,000957 & 0,0007863 & 0,0854235 \\
\hline m196 & 588 & 0,0024968 & 0,1470605 & 0,0033498 & 0,0125912 & 0,008892 & 0,5565738 \\
\hline m197 & 602 & 0,0024905 & 0,0098283 & 0,0004803 & 0,0010664 & 0,000924 & 0,0675595 \\
\hline m198 & 602 & 0,0015333 & 0,0068415 & 0,0004028 & 0,002957 & 0,0006845 & 0,0651638 \\
\hline m199 & 609 & 0,0021955 & 0,005365 & 0,0005468 & 0,0005 & 0,000911 & 0,0868063 \\
\hline m200 & 609 & 0,0029688 & 0,0203318 & 0,0005155 & 0,0009938 & 0,0022478 & 0,1132545 \\
\hline m201 & 720 & 0,00163 & 0,0044443 & 0,0008625 & 0,0005638 & 0,0026608 & 0,0216613 \\
\hline m202 & 720 & 0,0012813 & 0,0335508 & 0,00041 & 0,0006542 & 0,0011948 & 0,0399555 \\
\hline $\mathrm{m} 203$ & 721 & 0,0022958 & 0,0035913 & 0,0009395 & 0,0005472 & 0,0009178 & 0,0214095 \\
\hline
\end{tabular}




\begin{tabular}{|c|c|c|c|c|c|c|c|}
\hline m204 & 721 & 0,00025 & 0,34176 & 0,000243 & 0,0025406 & 0,0212345 & 0,0736498 \\
\hline m205 & 722 & 0,0015185 & 0,009062 & 0,0009888 & 0,00025 & 0,0015625 & 0,0506273 \\
\hline m206 & 722 & 0,0013253 & 0,0292815 & 0,001044 & 0,0012037 & 0,0025015 & 0,0411363 \\
\hline m207 & 723 & 0,0013083 & 0,0052018 & 0,000963 & 0,0005162 & 0,0011455 & 0,0226735 \\
\hline m208 & 723 & 0,0020683 & 0,0207998 & 0,0010808 & 0,0005 & 0,002543 & 0,0284978 \\
\hline m209 & 724 & 0,00025 & 0,047178 & 0,0015233 & 0,0238919 & 0,0040623 & 0,147146 \\
\hline $\mathrm{m} 210$ & 724 & 0,00025 & 0,0399258 & 0,0012243 & 0,0005 & 0,003015 & 0,0475833 \\
\hline $\mathrm{m} 211$ & 725 & 0,00025 & 0,0056273 & 0,0005725 & 0,00025 & 0,0008238 & 0,0285358 \\
\hline $\mathrm{m} 212$ & 725 & 0,00025 & 0,1644735 & 0,0004208 & 0,0025368 & 0,003844 & 0,3711735 \\
\hline $\mathrm{m} 213$ & 726 & 0,001358 & 0,1351318 & 0,0008283 & 0,0013045 & 0,0053765 & 0,0897065 \\
\hline $\mathrm{m} 214$ & 726 & 0,0015205 & 0,0167338 & 0,000474 & 0,0005 & 0,0017553 & 0,0316925 \\
\hline $\mathrm{m} 215$ & 727 & 0,00025 & 0,0069448 & 0,000364 & 0,0006534 & 0,00072 & 0,0307518 \\
\hline $\mathrm{m} 216$ & 727 & 0,0100253 & 0,0173823 & 0,001078 & 0,0012809 & 0,0080903 & 0,0462228 \\
\hline $\mathrm{m} 217$ & 728 & 0,0064193 & 0,0036755 & 0,0006295 & 0,0008435 & 0,0005843 & 0,022087 \\
\hline m218 & 728 & 0,00025 & 0,031905 & 0,0004508 & 0,0007949 & 0,0012033 & 0,0355703 \\
\hline $\mathrm{m} 219$ & 729 & 0,00025 & 0,0261143 & 0,0008668 & 0,0026377 & 0,0019605 & 0,0689603 \\
\hline m220 & 729 & 0,00025 & 0,0514655 & 0,001012 & 0,0048191 & 0,0033038 & 0,1082453 \\
\hline m221 & 730 & 0,00025 & 0,0690653 & 0,0022983 & 0,0350352 & 0,0144705 & 1,184459 \\
\hline m222 & 730 & 0,00025 & 0,0335205 & 0,0005303 & 0,0009999 & 0,0018165 & 0,0745925 \\
\hline m223 & 731 & 0,00025 & 1,209257 & 0,00336 & 0,0276505 & 0,054504 & 1,5340823 \\
\hline m224 & 731 & 0,00025 & 0,0396953 & 0,0005543 & 0,000811 & 0,002206 & 0,0452203 \\
\hline m225 & 732 & 0,00025 & 0,0120628 & 0,0005183 & 0,0007293 & 0,0020343 & 0,0318143 \\
\hline m226 & 732 & 0,00025 & 0,0383683 & 0,0004435 & 0,0008392 & 0,0020238 & 0,0427873 \\
\hline m227 & 733 & 0,00025 & 0,0532495 & 0,0004628 & 0,0034033 & 0,0030783 & 0,3357215 \\
\hline m228 & 733 & 0,00025 & 0,198247 & 0,000756 & 0,0020372 & 0,0089023 & 0,1254098 \\
\hline m229 & 734 & 0,00025 & 0,7002248 & 0,0010175 & 0,0019068 & 0,0101485 & 0,4791013 \\
\hline $\mathrm{m} 230$ & 734 & 0,024651 & 1,5391785 & 0,0012413 & 0,0035012 & 0,0047245 & 0,1039928 \\
\hline m231 & 735 & 0,00025 & 0,0344538 & 0,0003953 & 0,0006626 & 0,0019893 & 0,188237 \\
\hline m232 & 735 & 0,00025 & 1,5184425 & 0,0013448 & 0,0026593 & 0,0027128 & 0,5864128 \\
\hline m233 & 736 & 0,00025 & 0,0640035 & 0,00036 & 0,0016792 & 0,003166 & 0,389101 \\
\hline m234 & 736 & 0,0013925 & 0,088952 & 0,0012223 & 0,0011493 & 0,0036623 & 0,0852475 \\
\hline m235 & 737 & 0,001448 & 0,02454 & 0,0007175 & 0,0005 & 0,0031008 & 0,0811993 \\
\hline m236 & 737 & 0,0015833 & 0,0191043 & 0,0018955 & 0,0010176 & 0,0033978 & 0,0373163 \\
\hline m237 & 738 & 0,0035088 & 0,0164218 & 0,0011685 & 0,0029186 & 0,0028525 & 0,0983085 \\
\hline m238 & 738 & 0,004003 & 0,031289 & 0,0009178 & 0,0012797 & 0,004132 & 0,0433053 \\
\hline m239 & 739 & 0,0024938 & 0,0595988 & 0,0008288 & 0,0063604 & 0,0409395 & 1,84327 \\
\hline m240 & 739 & 0,00025 & 0,015205 & 0,000742 & 0,0009882 & 0,0018378 & 0,0651895 \\
\hline m241 & 702 & 0,0015825 & 0,005018 & 0,0004948 & 0,0010358 & 0,0009023 & 0,0243545 \\
\hline m242 & 702 & 0,00025 & 0,2475123 & 0,0244265 & 0,006056 & 0,008283 & 1,8385308 \\
\hline m243 & 703 & 0,0013515 & 0,006425 & 0,0006675 & 0,0005129 & 0,0012035 & 0,0335778 \\
\hline $\mathrm{m} 244$ & 703 & 0,0014538 & 0,0208018 & 0,001407 & 0,0005 & 0,002333 & 0,074442 \\
\hline m245 & 704 & 0,0012588 & 0,0037205 & 0,0019573 & 0,0004573 & 0,0007355 & 0,0465248 \\
\hline $\mathrm{m} 246$ & 704 & 0,0013938 & 0,0146738 & 0,00092 & 0,0005 & 0,0011495 & 0,1111958 \\
\hline
\end{tabular}




\begin{tabular}{|c|c|c|c|c|c|c|c|}
\hline m247 & 705 & 0,0036965 & 0,0032805 & 0,0005883 & 0,0010715 & 0,0014483 & 0,0173988 \\
\hline m248 & 705 & 0,0013418 & 0,028465 & 0,0017575 & 0,0011876 & 0,0017625 & 0,0479685 \\
\hline m249 & 706 & 0,0014658 & 0,4043615 & 0,0008888 & 0,0039291 & 0,010693 & 0,285702 \\
\hline m250 & 706 & 0,0013463 & 0,041775 & 0,0005373 & 0,0006371 & 0,0010275 & 0,0617778 \\
\hline m251 & 707 & 0,0012825 & 0,2015185 & 0,0004118 & 0,002334 & 0,005532 & 0,1134995 \\
\hline m252 & 707 & 0,00025 & 0,0914423 & 0,0003535 & 0,001176 & 0,0019623 & 0,2176115 \\
\hline m253 & 708 & 0,00025 & 0,0020168 & 0,0004453 & 0,0008003 & 0,0003798 & 0,0332858 \\
\hline m254 & 708 & 0,0013203 & 0,0162905 & 0,0008245 & 0,0005 & 0,001007 & 0,040663 \\
\hline m255 & 709 & 0,001872 & 0,0114138 & 0,0055713 & 0,001461 & 0,0048038 & 0,0840078 \\
\hline m256 & 709 & 0,00025 & 0,0461333 & 0,0007415 & 0,0008122 & 0,0016888 & 0,0499238 \\
\hline m257 & 676 & 0,001297 & 0,006281 & 0,000963 & 0,0016665 & 0,0015388 & 0,0683478 \\
\hline m258 & 676 & 0,00025 & 0,360648 & 0,0004595 & 0,0043196 & 0,0151213 & 0,1869085 \\
\hline m259 & 678 & 0,001424 & 0,0548593 & 0,0011585 & 0,0089513 & 0,0039345 & 0,1820023 \\
\hline m260 & 678 & 0,00025 & 0,1334303 & 0,0005413 & 0,0016837 & 0,005121 & 0,0860263 \\
\hline m261 & 680 & 0,00025 & 0,0018253 & 0,0005198 & 0,0005 & 0,0003335 & 0,026557 \\
\hline m262 & 680 & 0,00025 & 0,0226145 & 0,000884 & 0,0005 & 0,0018503 & 0,0661375 \\
\hline m263 & 682 & 0,00025 & 0,074154 & 0,0006803 & 0,0017613 & 0,0035755 & 0,1866058 \\
\hline m264 & 682 & 0,00025 & 0,0825215 & 0,001144 & 0,0019857 & 0,0061873 & 0,156677 \\
\hline m265 & 684 & 0,00025 & 0,1790588 & 0,007026 & 0,0615545 & 0,0365708 & 0,7380528 \\
\hline m266 & 684 & 0,00025 & 0,0069545 & 0,0007358 & 0,0008018 & 0,0012203 & 0,0245598 \\
\hline m267 & 686 & 0,00025 & 0,0040195 & 0,001019 & 0,0005731 & 0,0010538 & 0,0369238 \\
\hline m268 & 686 & 0,00025 & 0,0071763 & 0,0004075 & 0,0005 & 0,0008345 & 0,0251233 \\
\hline m269 & 688 & 0,0022025 & 0,0031373 & 0,000461 & 0,0006935 & 0,0022233 & 0,0274498 \\
\hline m270 & 688 & 0,0015608 & 0,0709128 & 0,0006018 & 0,0013302 & 0,0047035 & 0,0739673 \\
\hline m271 & 690 & 0,0020288 & 0,00289 & 0,0043483 & 0,0008726 & 0,0010233 & 0,0924058 \\
\hline m272 & 690 & 0,0012923 & 0,0072295 & 0,0006695 & 0,0005 & 0,00189 & 0,034259 \\
\hline m273 & 452 & 0,0019485 & 0,005112 & 0,0016093 & 0,00025 & 0,002261 & 0,0719573 \\
\hline m274 & 452 & 0,00025 & 0,0123805 & 0,0005968 & 0,0005 & 0,001103 & 0,0250715 \\
\hline m275 & 454 & 0,0019073 & 0,088195 & 0,0009735 & 0,0017409 & 0,0025775 & 0,1165363 \\
\hline m276 & 454 & 0,00025 & 0,011134 & 0,000723 & 0,0005 & 0,0008303 & 0,030339 \\
\hline m277 & 456 & 0,001922 & 0,0193435 & 0,000429 & 0,00025 & 0,0009738 & 0,0203435 \\
\hline m278 & 456 & 0,0024573 & 0,0082058 & 0,0006868 & 0,00025 & 0,0007135 & 0,0324693 \\
\hline m279 & 457 & 0,00025 & 0,0043273 & 0,0002388 & 0,0005 & 0,0002475 & 0,0290343 \\
\hline m280 & 457 & 0,00025 & 0,0325953 & 0,000215 & 0,0005749 & 0,0019553 & 0,0299458 \\
\hline m281 & 463 & 0,0017478 & 0,0217348 & 0,0003325 & 0,0005 & 0,0013275 & 0,035747 \\
\hline m282 & 463 & 0,0012728 & 0,0095688 & 0,000911 & 0,0008688 & 0,0012378 & 0,0590103 \\
\hline m283 & 464 & 0,00025 & 0,0118783 & 0,000559 & 0,0046145 & 0,0007415 & 0,1372225 \\
\hline m284 & 464 & 0,0014408 & 0,0146155 & 0,000304 & 0,0009925 & 0,0009765 & 0,01584 \\
\hline m285 & 467 & 0,00025 & 0,0122953 & 0,0006143 & 0,00025 & 0,0005003 & 0,0405383 \\
\hline m286 & 467 & 0,00025 & 0,0024918 & 0,0006568 & 0,0005045 & 0,0005495 & 0,016685 \\
\hline m287 & 710 & 0,0019335 & 0,0060323 & 0,001066 & 0,00025 & 0,0008725 & 0,017401 \\
\hline m288 & 710 & 0,0014035 & 0,0044455 & 0,0005328 & 0,0004331 & 0,0008973 & 0,027079 \\
\hline m289 & 711 & 0,0016475 & 0,039464 & 0,000855 & 0,0003769 & 0,0017798 & 0,0535485 \\
\hline
\end{tabular}




\begin{tabular}{|c|c|c|c|c|c|c|c|}
\hline m290 & 711 & 0,001805 & 0,091533 & 0,0005603 & 0,0007619 & 0,004413 & 0,0994583 \\
\hline m291 & 712 & 0,00025 & 0,2689488 & 0,0013515 & 0,003523 & 0,0097655 & 0,2487765 \\
\hline m292 & 712 & 0,0017385 & 0,0236485 & 0,0009555 & 0,001027 & 0,0014958 & 0,017876 \\
\hline m293 & 713 & 0,0015015 & 0,0033058 & 0,000938 & 0,0007401 & 0,0008095 & 0,0147968 \\
\hline m294 & 713 & 0,0022698 & 0,1128348 & 0,0009845 & 0,0022426 & 0,0049288 & 0,0646153 \\
\hline m295 & 714 & 0,00025 & 0,475679 & 0,001875 & 0,0047303 & 0,0382148 & 0,3007693 \\
\hline m296 & 714 & 0,0014685 & 0,0385103 & 0,0007283 & 0,0008994 & 0,0026395 & 0,101783 \\
\hline m297 & 715 & 0,0019333 & 0,0607853 & 0,0012118 & 0,002468 & 0,0096943 & 0,1199108 \\
\hline m298 & 715 & 0,00025 & 0,107612 & 0,0008568 & 0,0018673 & 0,004858 & 0,0922015 \\
\hline m299 & 716 & 0,00025 & 0,0281005 & 0,0011953 & 0,0032994 & 0,0020285 & 0,0624785 \\
\hline m300 & 716 & 0,0020613 & 0,0170333 & 0,0009553 & 0,0008231 & 0,0010268 & 0,037837 \\
\hline m301 & 717 & 0,0013183 & 0,0292403 & 0,0003208 & 0,0006156 & 0,0022073 & 0,026539 \\
\hline m302 & 717 & 0,0013828 & 0,0089418 & 0,0004845 & 0,0006163 & 0,000656 & 0,0626583 \\
\hline m303 & 760 & 0,00166 & 0,013693 & 0,000977 & 0,0011181 & 0,0009065 & 0,0300005 \\
\hline m304 & 760 & 0,0022685 & 0,0209433 & 0,000419 & 0,0005 & 0,0012273 & 0,0324695 \\
\hline m305 & 761 & 0,0023873 & 0,0078078 & 0,0015213 & 0,001606 & 0,001685 & 0,0754363 \\
\hline m306 & 761 & 0,0026855 & 0,0232833 & 0,0010938 & 0,0013296 & 0,0016405 & 0,1286518 \\
\hline m307 & 762 & 0,002109 & 0,006263 & 0,0007385 & 0,0011376 & 0,0005123 & 0,0259698 \\
\hline m308 & 762 & 0,00025 & 0,9612015 & 0,0020603 & 0,0111497 & 0,0144048 & 0,781395 \\
\hline m309 & 763 & 0,0025515 & 0,010579 & 0,0027258 & 0,0008687 & 0,002073 & 0,0219215 \\
\hline m310 & 763 & 0,0024458 & 0,0245173 & 0,0013433 & 0,0009078 & 0,0014593 & 0,0862878 \\
\hline m311 & 764 & 0,0021108 & 0,048919 & 0,000849 & 0,0082438 & 0,002187 & 0,0728525 \\
\hline m312 & 764 & 0,0026773 & 0,0313545 & 0,0020413 & 0,0162202 & 0,0013873 & 0,24498 \\
\hline m313 & 765 & 0,0029325 & 0,0114898 & 0,0005358 & 0,0005 & 0,0008675 & 0,0445545 \\
\hline m314 & 765 & 0,0026803 & 0,0253895 & 0,0012123 & 0,0009374 & 0,0011215 & 0,0317475 \\
\hline m315 & 766 & 0,0020043 & 2,1527908 & 0,0025513 & 0,0228234 & 0,059156 & 1,658742 \\
\hline m316 & 766 & 0,0030953 & 0,0593913 & 0,000754 & 0,0005 & 0,0008378 & 0,0687713 \\
\hline m317 & 767 & 0,0024653 & 0,1718105 & 0,0001903 & 0,0031783 & 0,0005963 & 0,2088783 \\
\hline m318 & 767 & 0,002586 & 0,0692293 & 0,0008128 & 0,0017266 & 0,0031393 & 0,078759 \\
\hline m319 & 768 & 0,0032868 & 0,0058408 & 0,0007795 & 0,00025 & 0,0008893 & 0,0353788 \\
\hline m320 & 768 & 0,0028385 & 0,0054925 & 0,000924 & 0,0011857 & 0,0030585 & 0,1182073 \\
\hline m321 & 769 & 0,0028598 & 0,0107263 & 0,0007168 & 0,00025 & 0,0008273 & 0,0424145 \\
\hline m322 & 769 & 0,005182 & 0,0178173 & 0,0006858 & 0,0005 & 0,0022315 & 0,0967393 \\
\hline m323 & 660 & 0,0021048 & 0,0152225 & 0,0002283 & 0,0057163 & 0,000584 & 0,0260108 \\
\hline m324 & 660 & 0,0016608 & 0,0087065 & 0,000146 & 0,00025 & 0,000529 & 0,0221175 \\
\hline m325 & 662 & 0,0050985 & 0,1264908 & 0,0004813 & 0,0025224 & 0,002196 & 0,1349093 \\
\hline m326 & 662 & 0,00025 & 0,0134413 & 0,0001418 & 0,0006167 & 0,000491 & 0,0155185 \\
\hline m327 & 664 & 0,004961 & 0,0028863 & 0,0007205 & 0,0005 & 0,000861 & 0,0533885 \\
\hline m328 & 664 & 0,0039735 & 0,1146768 & 0,0008528 & 0,0016239 & 0,0047205 & 0,0908088 \\
\hline m329 & 666 & 0,001793 & 0,0017975 & 0,0002295 & 0,00025 & 0,0016608 & 0,0698183 \\
\hline m330 & 666 & 0,0044425 & 0,0224798 & 0,0013873 & 0,0005 & 0,001942 & 0,1367678 \\
\hline $\begin{array}{l}\text { m331 } \\
\text { m332 }\end{array}$ & $\begin{array}{l}668 \\
668\end{array}$ & $\begin{array}{c}0,0030013 \\
0,00025\end{array}$ & $\begin{array}{l}0,0024488 \\
0,0033135\end{array}$ & $\begin{array}{c}0,000253 \\
0,0001463\end{array}$ & $\begin{array}{l}0,00025 \\
0,00025\end{array}$ & $\begin{array}{l}0,0003978 \\
0,0004995\end{array}$ & $\begin{array}{l}0,0252065 \\
0,0194228\end{array}$ \\
\hline
\end{tabular}




\begin{tabular}{|c|c|c|c|c|c|c|c|}
\hline m333 & 670 & 0,0037008 & 0,0909273 & 0,000457 & 0,0036294 & 0,0016893 & 0,1147628 \\
\hline m334 & 670 & 0,0045403 & 0,0866385 & 0,0010543 & 0,0005 & 0,0053428 & 0,1017618 \\
\hline m335 & 672 & 0,0039788 & 0,1031013 & 0,0003498 & 0,0017652 & 0,0022583 & 0,1291855 \\
\hline m336 & 672 & 0,0039138 & 0,077929 & 0,0004813 & 0,0005 & 0,0045985 & 0,0425685 \\
\hline m337 & 674 & 0,0025185 & 0,002396 & 0,0012505 & 0,0029589 & 0,0020548 & 0,0197805 \\
\hline m338 & 674 & 0,0044013 & 0,0852748 & 0,0005728 & 0,00025 & 0,0043255 & 0,0918895 \\
\hline m339 & 692 & 0,00025 & 0,1455295 & 0,0006298 & 0,0030753 & 0,0063098 & 0,272261 \\
\hline m340 & 692 & 0,00025 & 0,0198553 & 0,0003763 & 0,0013716 & 0,0031243 & 0,0385873 \\
\hline m341 & 693 & 0,00025 & 0,5130183 & 0,0008525 & 0,0081666 & 0,0282173 & 0,4053343 \\
\hline m342 & 693 & 0,00025 & 0,011304 & 0,0005018 & 0,0013856 & 0,0009993 & 0,0362935 \\
\hline m343 & 694 & 0,0023618 & 0,025697 & 0,0005608 & 0,0013434 & 0,0033518 & 0,4877573 \\
\hline m344 & 694 & 0,002462 & 0,0448968 & 0,000763 & 0,0022041 & 0,003041 & 0,142336 \\
\hline m345 & 695 & 0,00025 & 0,0064108 & 0,0005788 & 0,0031247 & 0,000657 & 0,027417 \\
\hline m346 & 695 & 0,00025 & 0,0078398 & 0,0002363 & 0,0011204 & 0,00081 & 0,0390533 \\
\hline m347 & 696 & 0,0020248 & 0,0078828 & 0,000617 & 0,001202 & 0,0013228 & 0,0364963 \\
\hline m348 & 696 & 0,0029038 & 0,020976 & 0,00121 & 0,0013392 & 0,001917 & 0,0650473 \\
\hline m349 & 697 & 0,0013193 & 0,0152093 & 0,0002368 & 0,0010536 & 0,000975 & 0,0856183 \\
\hline m350 & 697 & 0,00025 & 0,7986715 & 0,0018403 & 0,0197238 & 0,029893 & 7,8591918 \\
\hline m351 & 698 & 0,0023905 & 0,1024323 & 0,0020025 & 0,0026202 & 0,0055513 & 1,98736 \\
\hline m352 & 698 & 0,001812 & 0,1730875 & 0,0018625 & 0,0035447 & 0,0081638 & 1,340642 \\
\hline m353 & 699 & 0,00025 & 0,0236985 & 0,0004585 & 0,0023814 & 0,0021123 & 0,0823035 \\
\hline m354 & 699 & 0,0017733 & 0,0326775 & 0,0003788 & 0,0011288 & 0,0025915 & 0,0873768 \\
\hline m355 & 700 & 0,0016948 & 0,0110755 & 0,0004478 & 0,0025574 & 0,0018258 & 0,0646495 \\
\hline m356 & 700 & 0,001988 & 0,0427058 & 0,000295 & 0,0014046 & 0,0025035 & 0,059495 \\
\hline m357 & 701 & 0,001629 & 0,1524238 & 0,0005605 & 0,0047128 & 0,0067708 & 0,1553448 \\
\hline m358 & 701 & 0,0016888 & 0,058312 & 0,0004913 & 0,0086323 & 0,0037215 & 0,0788945 \\
\hline m359 & 750 & 0,00025 & 0,0072243 & 0,001001 & 0,0009346 & 0,0015088 & 0,0739428 \\
\hline m360 & 750 & 0,0021068 & 0,053403 & 0,0008918 & 0,0011687 & 0,004836 & 0,0771123 \\
\hline m361 & 751 & 0,00025 & 0,0088408 & 0,000257 & 0,0037672 & 0,001173 & 0,040161 \\
\hline m362 & 751 & 0,0022543 & 0,0186225 & 0,0001848 & 0,0010509 & 0,0012323 & 0,0391155 \\
\hline m363 & 752 & 0,0014215 & 0,0030965 & 0,000253 & 0,0006509 & 0,0002983 & 0,0418885 \\
\hline $\begin{array}{l}\text { m364 } \\
\text { m365 }\end{array}$ & $\begin{array}{l}752 \\
753\end{array}$ & $\begin{array}{c}0,0013495 \\
0,00025\end{array}$ & $\begin{array}{l}0,0707158 \\
0,0405618\end{array}$ & $\begin{array}{c}0,0006168 \\
0,000025\end{array}$ & $\begin{array}{c}0,0127615 \\
0,00025\end{array}$ & $\begin{array}{c}0,00566 \\
0,000378\end{array}$ & $\begin{array}{l}0,1593548 \\
0,0687645\end{array}$ \\
\hline m366 & 753 & 0,00025 & 0,0041435 & 0,0001448 & 0,0002122 & 0,0007725 & 0,0337148 \\
\hline m367 & 754 & 0,0013138 & 0,0651578 & 0,0004495 & 0,0006627 & 0,0046538 & 0,0786648 \\
\hline m368 & 754 & 0,0014105 & 0,0725348 & 0,0007478 & 0,0008628 & 0,0031785 & 0,1144238 \\
\hline m369 & 755 & 0,0027563 & 0,2349538 & 0,0008005 & 0,0010078 & 0,0137463 & 0,185688 \\
\hline m370 & 755 & 0,001252 & 0,195459 & 0,0004115 & 0,00088 & 0,009613 & 0,127006 \\
\hline m371 & 756 & 0,0013955 & 0,0097713 & 0,0002233 & 0,00025 & 0,000687 & 0,017721 \\
\hline m372 & 756 & 0,0014883 & 0,0087405 & 0,0001915 & 0,00025 & 0,000995 & 0,0292753 \\
\hline m373 & 757 & 0,00025 & 0,0341965 & 0,0002915 & 0,0012398 & 0,002079 & 0,0743668 \\
\hline m374 & 757 & 0,0015593 & 0,0890178 & 0,0002503 & 0,0008432 & 0,0031995 & 0,112606 \\
\hline m375 & 758 & 0,00025 & 0,0023433 & 0,000226 & 0,0004296 & 0,0005798 & 0,06148 \\
\hline m376 & 758 & 0,00025 & 0,164257 & 0,000219 & 0,0015915 & 0,0059775 & 0,1140748 \\
\hline m377 & 759 & 0,00025 & 0,6327988 & 0,0007888 & 0,0185432 & 0,0490783 & 0,8562363 \\
\hline m378 & 759 & 0,00025 & 0,1094813 & 0,0004925 & 0,0015665 & 0,0027743 & 0,082174 \\
\hline
\end{tabular}


Table Analyzed

Column A

vs

Column B
$\mathrm{Cr}$

Reservatório

vs

Rede

0,0257

Gaussian Approximation

Yes

Two-tailed

54330,37910

19950

Mann-Whitney $U$

89

Number of values $\quad 240 \quad 189$

Minimum $\quad 0,00025 \quad 0,00025$

$25 \%$ Percentile $\quad 0,00025 \quad 0,00025$

Median $\quad 0,001470 \quad 0,001308$

$75 \%$ Percentile $\quad 0,002358 \quad 0,001928$

Maximum $\quad 0,02465 \quad 0,007509$

Mean $\quad 0,001599 \quad 0,001270$

Std. Deviation $\quad 0,001998 \quad 0,001248$

Std. Error $\quad 0,0001290 \quad 0,00009081$

Lower $95 \% \mathrm{Cl} \quad 0,001345 \quad 0,001091$

Upper $95 \% \mathrm{Cl} \quad 0,001853 \quad 0,001449$ 
Table Analyzed

Column A

vs

Column B
$\mathrm{Cu}$

Reservatório

vs

Rede

0,8775

Gaussian Approximation

ns

No

Two-tailed

51403,40832

22480

Mann-Whitney U

$\begin{array}{lrr}\text { Number of values } & 240 & 189 \\ \text { Minimum } & 0,001275 & 0,001055 \\ 25 \% \text { Percentile } & 0,007181 & 0,006346 \\ \text { Median } & 0,01548 & 0,01532 \\ 75 \% \text { Percentile } & 0,04030 & 0,05782 \\ \text { Maximum } & 1,539 & 2,153 \\ & & \\ \text { Mean } & 0,06292 & 0,07642 \\ \text { Std. Deviation } & 0,1840 & 0,2082 \\ \text { Std. Error } & 0,01188 & 0,01515 \\ & & \\ \text { Lower } 95 \% \mathrm{Cl} & 0,03952 & 0,04654 \\ \text { Upper } 95 \% \mathrm{Cl} & 0,08632 & 0,1063\end{array}$

Table Analyzed

$\mathrm{Mn}$

Column A

Reservatório

vs

vs

Column B

Rede

Mann Whitney test

Pvalue

0,2920

Exact or approximate $P$ value?

$P$ value summary

Are medians signif. different? $(P<0.05)$

One- or two-tailed $P$ value?

Sum of ranks in column A,B

Mann-Whitney $U$

Gaussian Approximation

ns

No

Two-tailed

50256,41979

21340

$\begin{array}{lrr}\text { Number of values } & 240 & 189 \\ \text { Minimum } & 0,000025 & 0,000025 \\ \text { 25\% Percentile } & 0,0002927 & 0,0003059 \\ \text { Median } & 0,0004906 & 0,0005198 \\ \text { 75\% Percentile } & 0,0008903 & 0,0009388 \\ \text { Maximum } & 0,04280 & 0,009617 \\ & & \\ \text { Mean } & 0,001072 & 0,0008888 \\ \text { Std. Deviation } & 0,003560 & 0,001202 \\ \text { Std. Error } & 0,0002298 & 0,00008742 \\ & & \\ \text { Lower } 95 \% \mathrm{Cl} & 0,0006194 & 0,0007164 \\ \text { Upper } 95 \% \mathrm{Cl} & 0,001525 & 0,001061\end{array}$




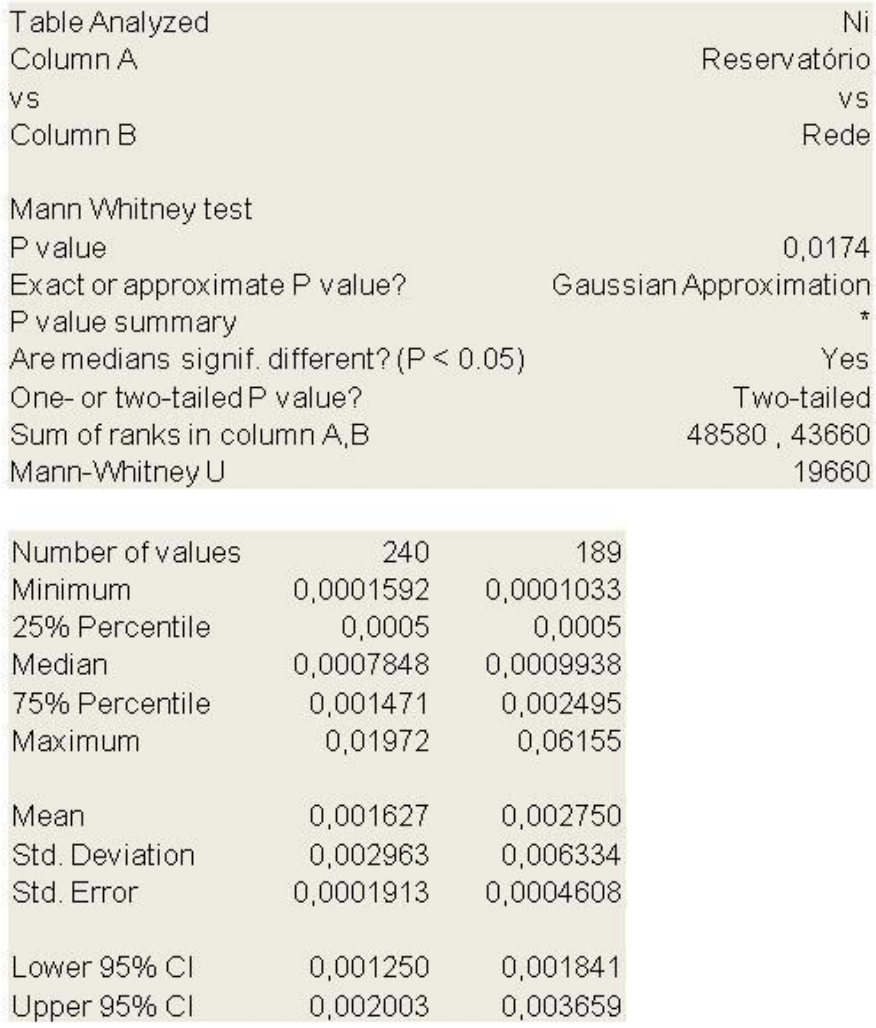

Table Analyzed

Column B

Mann Whitney test

Pvalue

Exact or approximate $P$ value?

Gaussian Approximation

$P$ value summary

ns

Are medians signif. different? $(P<0.05)$

No

One- or two-tailed $P$ value?

Two-tailed

Sum of ranks in column $A, B$ 49712,42523

Mann-Whitney U 20790

$\begin{array}{lrr}\text { Number of values } & 240 & 189 \\ \text { Minimum } & 0,0001958 & 0,0002058 \\ \text { 25\% Percentile } & 0,0007364 & 0,0008255 \\ \text { Median } & 0,001408 & 0,001539 \\ \text { 75\% Percentile } & 0,002941 & 0,003181 \\ \text { Maximum } & 0,03684 & 0,05916 \\ & & \\ \text { Mean } & 0,002695 & 0,005025 \\ \text { Std. Deviation } & 0,004343 & 0,01068 \\ \text { Std. Error } & 0,0002803 & 0,0007772 \\ & & \\ \text { Lower } 95 \% \mathrm{Cl} & 0,002143 & 0,003491 \\ \text { Upper } 95 \% \mathrm{Cl} & 0,003247 & 0,006558\end{array}$


Table Analyzed

Column A

vs

Column B
Zn

Reservatório

vs

Rede

0,0279

Whitney test

$P$ value

Exact or approximate $P$ value?

P value summary

Are medians signif. different? $(P<0.05)$

One- or two-tailed $P$ value?

Sum of ranks in column A,B

Mann-Whitney U

48797,43438

19880

$\begin{array}{lrr}\text { Number of values } & 240 & 189 \\ \text { Minimum } & 0,006116 & 0,006875 \\ \text { 25\% Percentile } & 0,02620 & 0,02879 \\ \text { Median } & 0,04645 & 0,05063 \\ \text { 75\% Percentile } & 0,08432 & 0,1253 \\ \text { Maximum } & 7,859 & 1,987 \\ & & \\ \text { Mean } & 0,1396 & 0,1539 \\ \text { Std. Deviation } & 0,5797 & 0,2966 \\ \text { Std. Error } & 0,03742 & 0,02157 \\ & & \\ \text { Lower } 95 \% \mathrm{Cl} & 0,06592 & 0,1113 \\ \text { Upper } 95 \% \mathrm{Cl} & 0,2134 & 0,1964\end{array}$




\section{APÊNDICE D - Testes Estatísticos das concentrações de metais em amostras água de reservatórios de amianto e polietileno.}

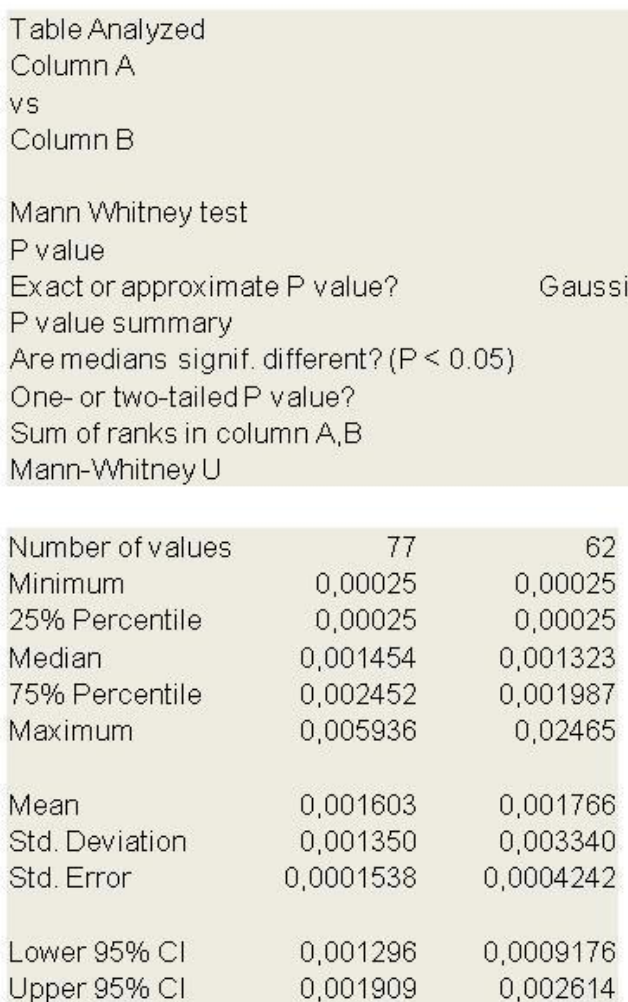

\begin{tabular}{|c|c|c|}
\hline \multicolumn{2}{|l|}{ Table Analyzed } & $\begin{array}{r}\mathrm{Cu} \\
\text { Amianto }\end{array}$ \\
\hline \multicolumn{2}{|l|}{ vs } & vs \\
\hline \multicolumn{2}{|l|}{ Column B } & Polietileno \\
\hline \multicolumn{3}{|l|}{ Mann Whitney test } \\
\hline \multicolumn{2}{|l|}{ Pvalue } & 0,0971 \\
\hline \multicolumn{2}{|c|}{ Exact or approximate $P$ value? } & Gaussian Approximation \\
\hline \multicolumn{2}{|c|}{ P value summary } & \\
\hline \multicolumn{2}{|c|}{ Are medians signif. different? $(P<0.05)$} & No \\
\hline \multicolumn{2}{|c|}{ One- or two-tailed $\mathrm{P}$ value? } & Two-tailed \\
\hline \multicolumn{2}{|c|}{ Sum of ranks in column $\mathrm{A}, \mathrm{B}$} & 4998,4732 \\
\hline \multicolumn{2}{|l|}{ Mann-WhitneyU } & 1995 \\
\hline Number of values & 77 & 62 \\
\hline Minimum & 0,002492 & 0,003298 \\
\hline $25 \%$ Percentile & 0,009733 & 0,01406 \\
\hline Median & 0,02151 & 0,03160 \\
\hline $75 \%$ Percentile & 0,04524 & 0,08723 \\
\hline Maximum & 0,9784 & 1,539 \\
\hline Mean & 0,07564 & 0.1209 \\
\hline Std. Deviation & 0,1858 & 0,2858 \\
\hline Std. Error & 0,02118 & 0,03630 \\
\hline Lower $95 \% \mathrm{Cl}$ & 0,03346 & 0,04829 \\
\hline Upper $95 \% \mathrm{Cl}$ & 0,1178 & 0,1934 \\
\hline
\end{tabular}


Table Analyzed

Column A

vs

Column B

Mann Whitney test

Pvalue

Exact or approximate $P$ value?

$P$ value summary

Are medians signif. different? $(P<0.05)$

One- or two-tailed $P$ value?

Sum of ranks in column A,B

Mann-Whitney U
$\mathrm{Mn}$

Amianto

vs

Polietileno

0,9493

Gaussian Approximation

\section{ns}

No

Two-tailed

5406,4325

2372

$\begin{array}{lrr}\text { Number of values } & 77 & 62 \\ \text { Minimum } & 0,0001275 & 0,000025 \\ \text { 25\% Percentile } & 0,0003339 & 0,0003501 \\ \text { Median } & 0,0005603 & 0,0005499 \\ 75 \% \text { Percentile } & 0,0009155 & 0,0009694 \\ \text { Maximum } & 0,02443 & 0,04280 \\ & & \\ \text { Mean } & 0,0009993 & 0,001525 \\ \text { Std. Deviation } & 0,002744 & 0,005543 \\ \text { Std. Error } & 0,0003127 & 0,0007040 \\ & & \\ \text { Lower } 95 \% \mathrm{Cl} & 0,0003765 & 0,0001168 \\ \text { Upper } 95 \% \mathrm{Cl} & 0,001622 & 0,002932\end{array}$

Table Analyzed

Column A

vs

Column B

Mann Whitney test

Pvalue

Exact or approximate $P$ value?

$P$ value summary

Are medians signif. different? $(P<0.05)$

One- or two-tailed $P$ value?

Sum of ranks in column A,B

Mann-Whitney U
Amianto

vs

Polietileno

0,7904

Gaussian Approximation

ns

No

Two-tailed

5327,4403

2324

$\begin{array}{lrr}\text { Number of values } & 77 & 62 \\ \text { Minimum } & 0,00025 & 0,0002122 \\ \text { 25\% Percentile } & 0,0005 & 0,0005872 \\ \text { Median } & 0,0009615 & 0,001014 \\ \text { 75\% Percentile } & 0,001797 & 0,001614 \\ \text { Maximum } & 0,01909 & 0,01972 \\ & & \\ \text { Mean } & 0,002117 & 0,001742 \\ \text { Std. Deviation } & 0,003618 & 0,002907 \\ \text { Std. Error } & 0,0004123 & 0,0003692 \\ & & \\ \text { Lower } 95 \% \mathrm{Cl} & 0,001296 & 0,001004 \\ \text { Upper } 95 \% \mathrm{Cl} & 0,002939 & 0,002480\end{array}$


Table Analyzed

Column A

vs

Column B

Mann Whitney test

Pvalue

Exact or approximate $P$ value?

$P$ value summary

Are medians signif. different? $(P<0.05)$

One- or two-tailed $P$ value?

Sum of ranks in column A,B

Mann-Whitney U
$\mathrm{Pb}$

Amianto

vs

Polietileno

0,0701

Gaussian Approximation

ns

No

Two-tailed

4962,4768

1959

$\begin{array}{lrr}\text { Number of values } & 77 & 62 \\ \text { Minimum } & 0,0002523 & 0,0001995 \\ \text { 25\% Percentile } & 0,0009419 & 0,001153 \\ \text { Median } & 0,001681 & 0,002115 \\ 75 \% \text { Percentile } & 0,003091 & 0,004752 \\ \text { Maximum } & 0,03684 & 0,02989 \\ & & \\ \text { Mean } & 0,003116 & 0,004045 \\ \text { Std. Deviation } & 0,005424 & 0,005268 \\ \text { Std. Error } & 0,0006181 & 0,0006691 \\ & & \\ \text { Lower } 95 \% \mathrm{Cl} & 0,001885 & 0,002707 \\ \text { Upper } 95 \% \mathrm{Cl} & 0,004347 & 0,005383\end{array}$

Table Analyzed

Column A

vs

Amianto

Column B

Polietileno

Mann Whitney test

$P$ value

0,3634

Exact or approximate $P$ value?

$P$ value summary

Are medians signif. different? $(P<0.05)$

Gaussian Approximation

One- or two-tailed $P$ value?

Sum of ranks in column $A, B$

Two-tailed

Mann-Whitney U

5175,4555

$\begin{array}{lrr}\text { Number of values } & 77 & 62 \\ \text { Minimum } & 0,01201 & 0,01085 \\ \text { 25\% Percentile } & 0,03104 & 0,03875 \\ \text { Median } & 0,05463 & 0,06512 \\ \text { 75\% Percentile } & 0,09810 & 0,1051 \\ \text { Maximum } & 3,174 & 7,859 \\ & & \\ \text { Mean } & 0,1838 & 0,2291 \\ \text { Std. Deviation } & 0,4790 & 1,002 \\ \text { Std. Error } & 0,05459 & 0,1272 \\ & & \\ \text { Lower } 95 \% \mathrm{Cl} & 0,07511 & -0,02528 \\ \text { Upper } 95 \% \mathrm{Cl} & 0,2926 & 0,4834\end{array}$


$\mathrm{Cr}$
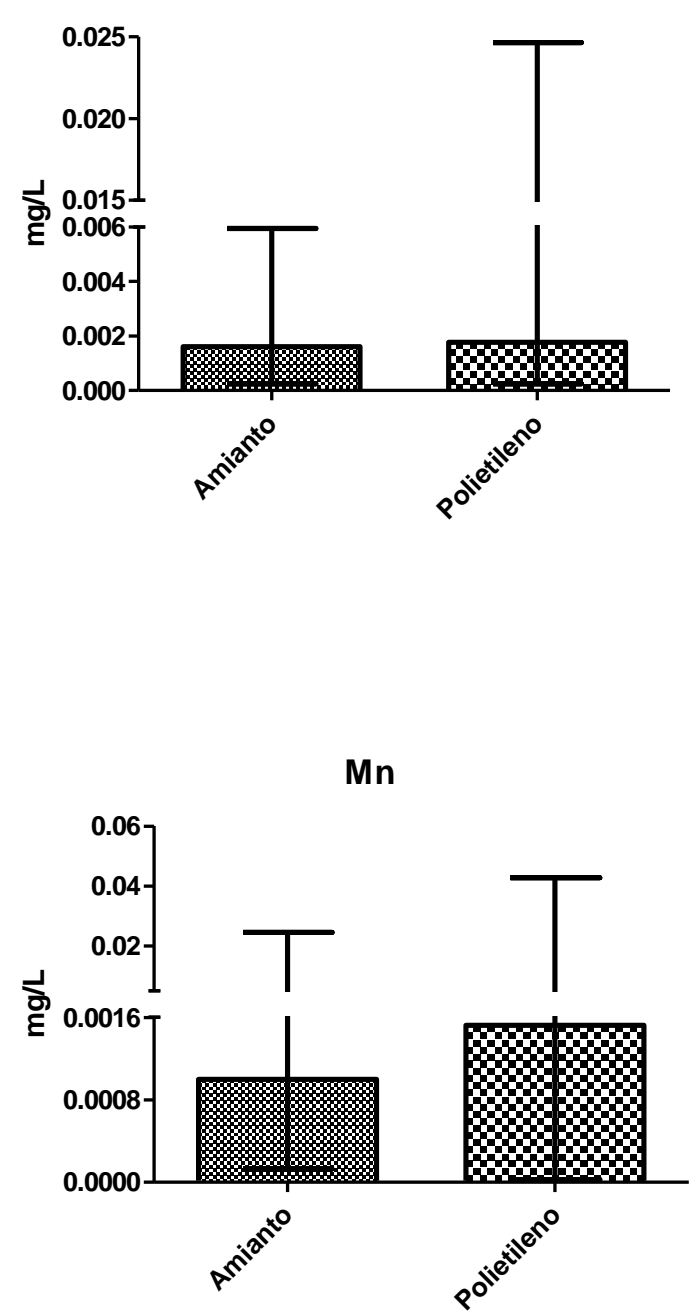

$\mathrm{Pb}$

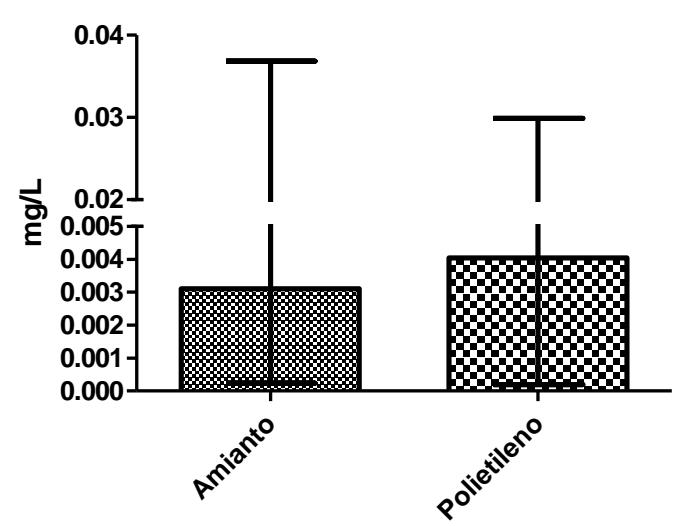

$\mathrm{Cu}$

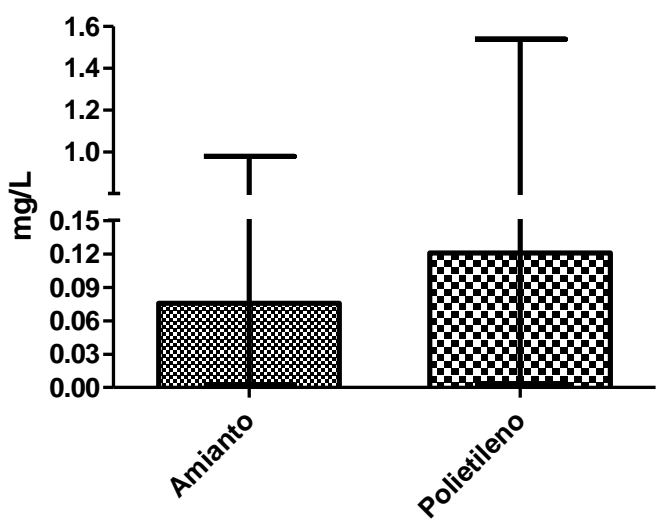

$\mathbf{N i}$

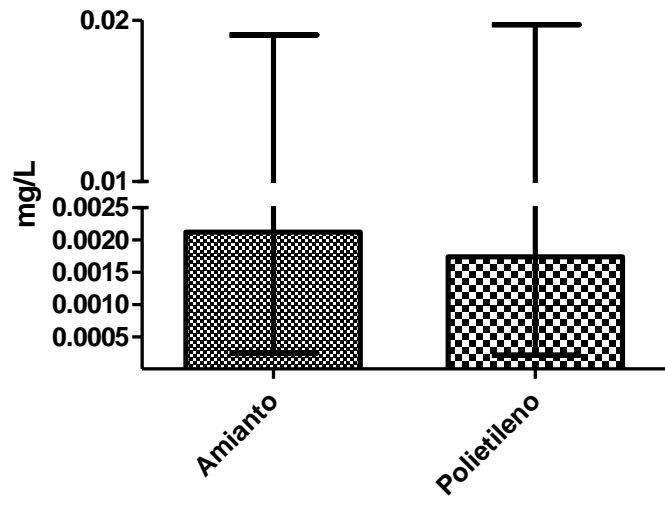

Zn

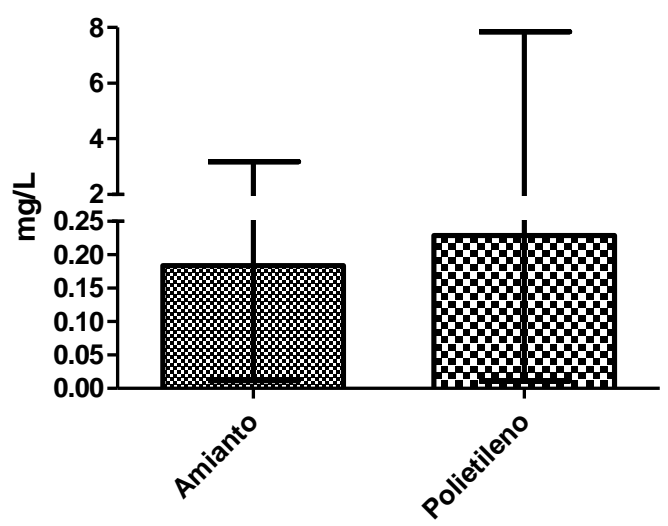




\section{APENDICE E - Testes estatísticos das concentrações de metais em amostras de água das regiões do município de Ribeirão Preto-SP.}

\begin{tabular}{|c|c|c|}
\hline Table Analyzed & $\mathrm{Cr}$ & \\
\hline \multicolumn{3}{|l|}{ Kruskal-Wallis test } \\
\hline P value & $P<0.0001$ & \\
\hline Exact or approximate P value? & Gaussian Approximation & \\
\hline P value summary & \#* & \\
\hline Do the medians vary signif. $(P<0.05)$ & Yes & \\
\hline Number of groups & 5 & \\
\hline Kruskal-Wallis statistic & 53,57 & \\
\hline Dunn's Multiple Comparison Test & Difference in rank sum & Significant? $P<0.05$ ? \\
\hline Centrovs Leste & 7,334 & No \\
\hline Centrovs Norte & $-92,02$ & Yes \\
\hline Centrovs Oeste & $-66,46$ & No \\
\hline Centrovs Sul & $-14,59$ & No \\
\hline Lestevs Norte & $-99,35$ & Yes \\
\hline Lestevs Oeste & $-73,79$ & Yes \\
\hline Lestevs Sul & $-21,92$ & No \\
\hline Nortevs Oeste & 25,56 & No \\
\hline Nortevs Sul & 77.43 & Yes \\
\hline Oestevs Sul & 51,87 & No \\
\hline Table Analyzed & $\mathrm{Cu}$ & \\
\hline \multicolumn{3}{|l|}{ Kruskal-Wallis test } \\
\hline \multirow[t]{2}{*}{ Pvalue } & $P<0.0001$ & \\
\hline & Gaussian & \\
\hline Exact or approximate P value? & Approximation & \\
\hline P value summary & \#\# & \\
\hline Do the medians vary signif. $(P<0.05)$ & Yes & \\
\hline Number of groups & 5 & \\
\hline \multirow[t]{2}{*}{ Kruskal-Wallis statistic } & 41,69 & \\
\hline & Difference in rank & \\
\hline Dunn's Multiple Comparison Test & sum & Significant? $P<0.05$ ? \\
\hline Centrovs Leste & $-149,2$ & Yes \\
\hline Centrovs Norte & $-94,25$ & Yes \\
\hline Centrovs Oeste & $-62,75$ & No \\
\hline Centrovs Sul & $-133,0$ & Yes \\
\hline Lestevs Norte & 54,96 & Yes \\
\hline Lestevs Oeste & 86,46 & Yes \\
\hline Lestevs Sul & 16,22 & No \\
\hline Nortevs Oeste & 31,50 & No \\
\hline Nortevs Sul & $-38,75$ & No \\
\hline Oestevs Sul & $-70,25$ & Yes \\
\hline
\end{tabular}




\begin{tabular}{|c|c|c|}
\hline Table Analyzed & $\mathrm{Mn}$ & \\
\hline \multicolumn{3}{|l|}{ Kruskal-Wallis test } \\
\hline P value & $P<0.0001$ & \\
\hline Exact or approximate $P$ value? & Gaussian Approximation & \\
\hline Pvalue summary & \#\# & \\
\hline Do the medians vary signif. $(P<0.05)$ & Yes & \\
\hline Number of groups & 5 & \\
\hline Kruskal-Wallis statistic & 34,99 & \\
\hline Dunn's Multiple Comparison Test & Difference in rank sum & Significant? $P<0.05$ ? \\
\hline Centrovs Leste & $-106,8$ & Yes \\
\hline Centrovs Norte & $-98,88$ & Yes \\
\hline Centrovs Oeste & $-25,01$ & No \\
\hline Centrovs Sul & $-104,1$ & Yes \\
\hline Leste vs Norte & 7,967 & No \\
\hline Lestevs Oeste & 81,83 & Yes \\
\hline Leste vs Sul & 2,700 & No \\
\hline Nortevs Oeste & 73,87 & Yes \\
\hline Nortevs Sul & $-5,267$ & No \\
\hline Oestevs Sul & $-79,13$ & Yes \\
\hline
\end{tabular}

\begin{tabular}{|c|c|c|}
\hline Table Analyzed & $\mathrm{Ni}$ & \\
\hline \multicolumn{3}{|l|}{ Kruskal-Wallis test } \\
\hline Pvalue & $P<0.0001$ & \\
\hline Exact or approximate $P$ value? & Gaussian Approximation & \\
\hline P value summary & \#* & \\
\hline Do the medians vary signif. $(P<0.05)$ & Yes & \\
\hline Number of groups & 5 & \\
\hline Kruskal-Wallis statistic & 39,77 & \\
\hline Dunn's Multiple Comparison Test & Difference in rank sum & Significant? $P<0.05$ ? \\
\hline Centrovs Leste & $-145,9$ & Yes \\
\hline Centro vs Norte & $-114,5$ & Yes \\
\hline Centrovs Oeste & $-77,06$ & No \\
\hline Centrovs Sul & $-161,9$ & Yes \\
\hline Lestevs Norte & 31,45 & No \\
\hline Lestevs Oeste & 68,88 & Yes \\
\hline Lestevs Sul & $-15,92$ & No \\
\hline Nortevs Oeste & 37,43 & No \\
\hline Nortevs Sul & $-47,37$ & No \\
\hline Oestevs Sul & $-84,80$ & Yes \\
\hline
\end{tabular}




\begin{tabular}{|c|c|c|}
\hline Table Analyzed & $\overline{\mathrm{Pb}}$ & \\
\hline \multicolumn{3}{|l|}{ Kruskal-Wallis test } \\
\hline Pvalue & $P<0.0001$ & \\
\hline Exact or approximate $P$ value? & Gaussian Approximation & \\
\hline Pvalue summary & - & \\
\hline Do the medians vary signif. $(\mathrm{P}<0.05)$ & Yes & \\
\hline Number of groups & 5 & \\
\hline Kruskal-Wallis statistic & 53,31 & \\
\hline Dunn's Multiple Comparison Test & Difference in rank sum & Significant? $P<0.05$ ? \\
\hline Centrovs Leste & $-155,1$ & Yes \\
\hline Centrovs Norte & $-97,27$ & Yes \\
\hline Centrovs Oeste & $-58,09$ & No \\
\hline Centrovs Sul & $-150,9$ & Yes \\
\hline Leste vs Norte & 57,81 & Yes \\
\hline Lestevs Oeste & 97,00 & Yes \\
\hline Lestevs Sul & 4,211 & No \\
\hline Nortevs Oeste & 39,18 & No \\
\hline Nortevs Sul & $-53,60$ & Yes \\
\hline bestevs Sul & -9279 & Yes \\
\hline
\end{tabular}

\begin{tabular}{|c|c|c|}
\hline Table Analyzed & $\mathrm{Zn}$ & \\
\hline \multicolumn{3}{|l|}{ Kruskal-Wallis test } \\
\hline Pvalue & 0,0003 & \\
\hline Exact or approximate $\mathrm{P}$ value? & Gaussian Approximation & \\
\hline P value summary & ネส & \\
\hline Do the medians vary signif. $(P<0.05)$ & Yes & \\
\hline Number of groups & 5 & \\
\hline Kruskal-Wallis statistic & 21,35 & \\
\hline Dunn's Multiple Comparison Test & Difference in rank sum & Significant? $P<0.05$ ? \\
\hline Centrovs Leste & $-89,37$ & No \\
\hline Centrovs Norte & $-67,45$ & No \\
\hline Centrovs Oeste & $-60,45$ & No \\
\hline Centrovs Sul & $-126,4$ & Yes \\
\hline Lestevs Norte & 21,93 & No \\
\hline Lestevs Oeste & 28,92 & No \\
\hline Lestevs Sul & $-37,01$ & No \\
\hline Nortevs Oeste & 6,998 & No \\
\hline Nortevs Sul & $-58,94$ & Yes \\
\hline Destevs Sul & $-65,94$ & Yes \\
\hline
\end{tabular}



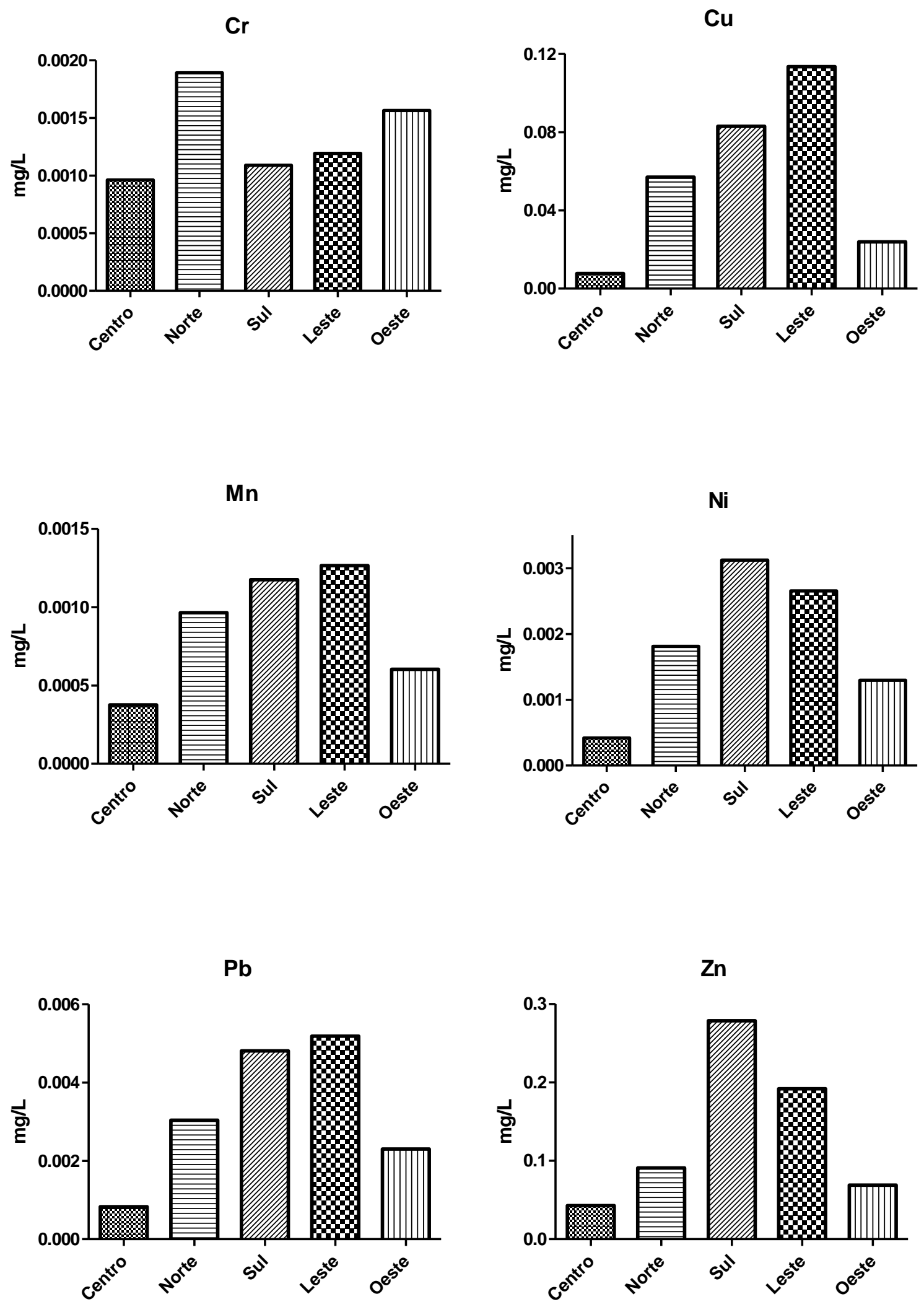
ANEXOS

(2)




\section{ANEXO A}

\section{Parecer do Comitê de Ética em Pesquisa da Escola de Enfermagem de Ribeirão Preto da Universidade de São Paulo}
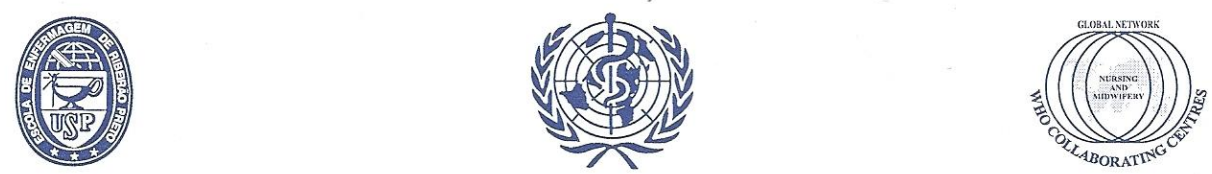

Escola de Enfermagem de Ribeirão Preto - Universidade de São Paulo

Centro Colaborador da Organização Mundial da Saúde para

o Desenvolvimento da Pesquisa em Enfermagem

Avenida Bandeirantes, 3900 - Campus Universitário - Ribeirão Preto - CEP 14040-902 - São Paulo - Brasil

FAX: (55) - 16-3633-3271 / TELEFONE: (55) - $16-3602-3382$

COMITÊ DE ÉTICA EM PESQUISA DA EERPIUSP

Of.CEP-EERP/USP - 209/2008

Ribeirão Preto, 21 de agosto de 2008

Prezada Senhora,

Comunicamos que o projeto de pesquisa, abaixo especificado, foi analisado e considerado APROVADO AD REFERENDUM pelo Comitê de Ética em Pesquisa da Escola de Enfermagem de Ribeirão Preto da Universidade de São Paulo, em 21 de agosto de 2008.

Protocolo:

$n^{\circ} 0943 / 2008$

Projeto:

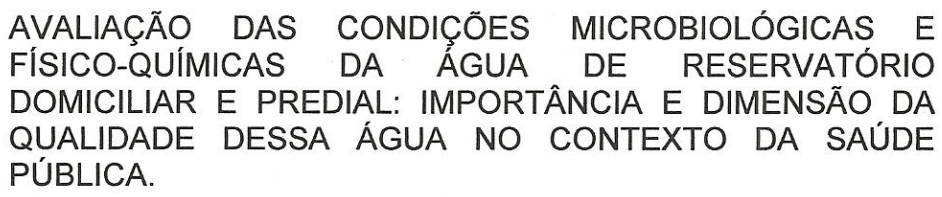

Pesquisadores: Susana Inés Segura Muñoz

Fabiana Cristina Julião

Em atendimento à Resolução 196/96, deverá ser encaminhado ao CEP o relatório final da pesquisa e a publicação de seus resultados, para acompanhamento, bem como comunicada qualquer intercorrência ou a sua interrupção.

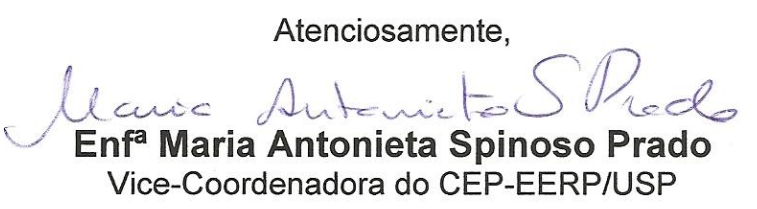

Ilma. Sra.

Profa Dra Susana Inés Segura Muñoz

Departamento de Enfermagem Materno-Infantil e Saúde Pública

Escola de Enfermagem de Ribeirão Preto - USP 
ANEXO B

\section{Autorização da Secretaria Municipal da Saúde}

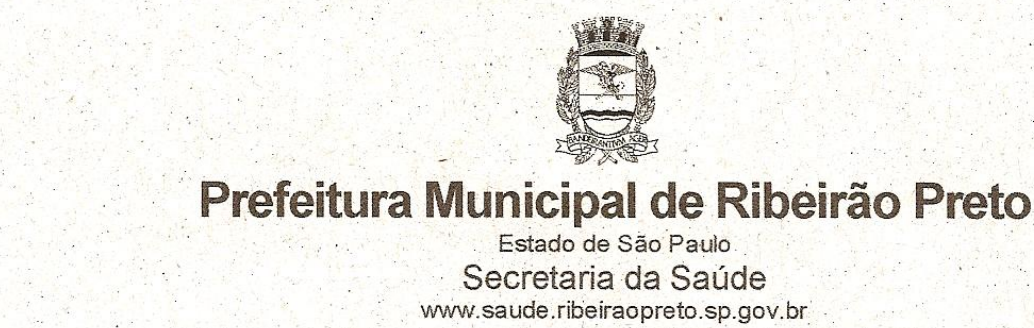

OF. $650 / 09-$ GS

RAS/ras

Ribeirão Preto, 09 de fevereiro de 2009

Prezada Senhora,

Em atenção à solicitação de autorização para a realização do Projeto intitulado "Avaliação das condições microbiológicas e físico-químicas da água de reservatório domiciliar e predial: importância $\mathrm{e}$ dimensão da qualidade desta água no contexto da saúde pública", informamos que somos favoráveis à realização do referido Projeto.

Solicitamos que os resultados da pesquisa sejam repassados ao Departamento de Vigilância em Saúde desta Secretaria.

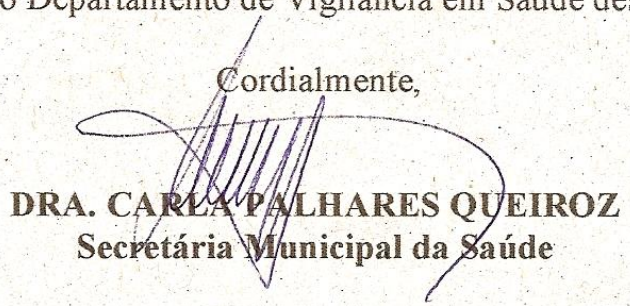

ILUSTRISSIMA SENHORA

PROF DRA. SUSANA INES SEGURA MUNOZ

COORDENADORA DO PROJETO

DEPARTAMENTO DE ENFERMAGEM MATERNO-INFANTIL E SAÚDE

PÚBLICA

ESCOLA DE ENFERMAGEM DE RIBEIRÃO PRETO - USP

NESTA 